\title{
Investigation of Artificially Generated and Ambient Carbonaceous Particulate Matter
}

\author{
PhD Thesis
}

By

\section{Máté Dániel Pintér}

Supervisor

Dr. Tibor Ajtai, PhD

senior research fellow

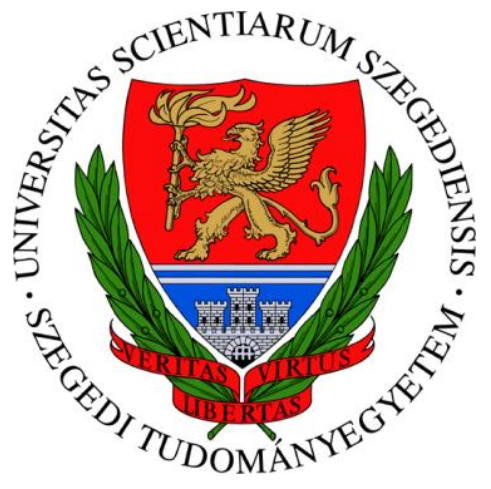

Doctoral School of Environmental Sciences

Department of Optics and Quantum Electronics

Faculty of Science and Informatics

University of Szeged

Szeged 


\section{TABLE OF CONTENTS}

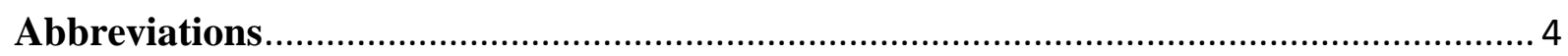

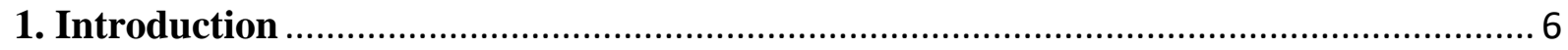

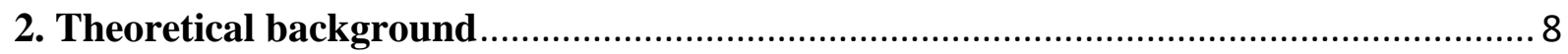

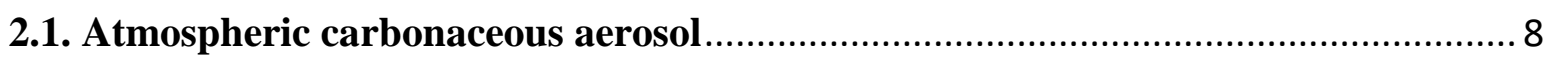

2.2. Significance of atmospheric carbonaceous aerosol........................................... 10

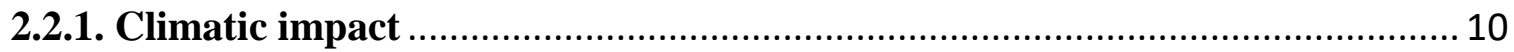

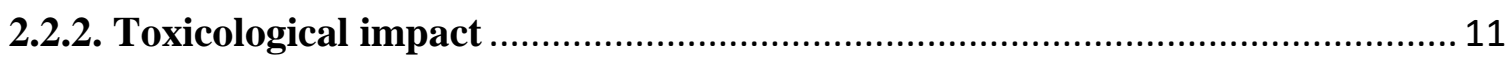

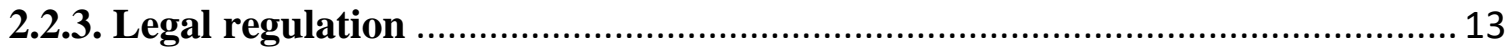

2.3. Parameters describing atmospheric carbonaceous particulate matter ................ 15

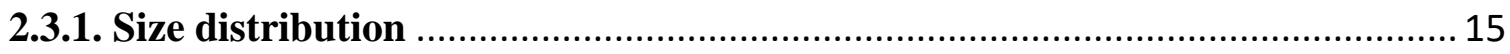

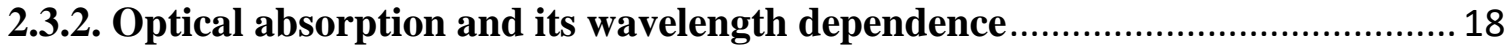

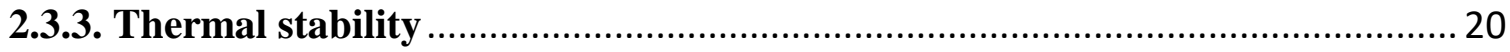

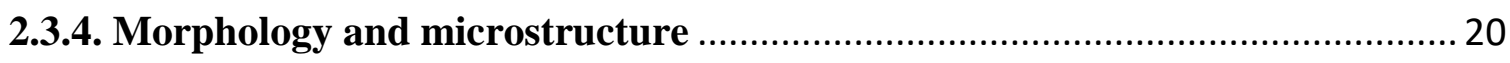

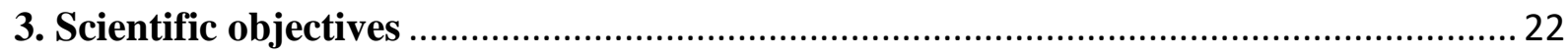

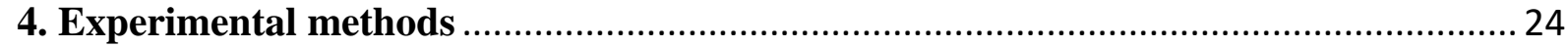

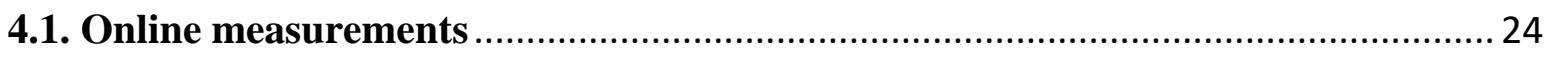

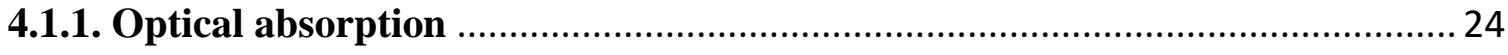

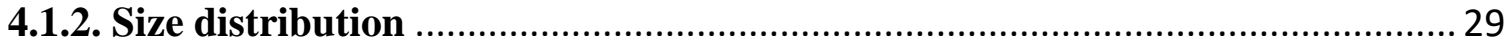

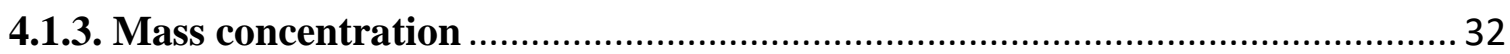

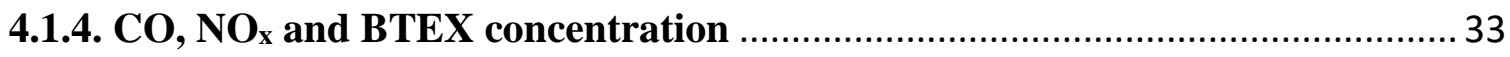

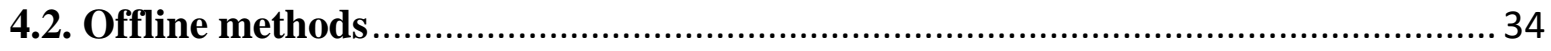

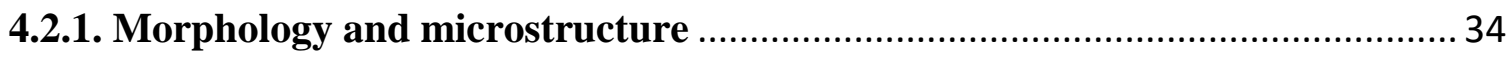

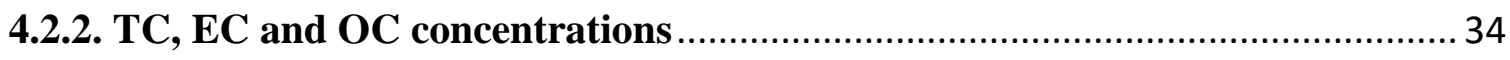

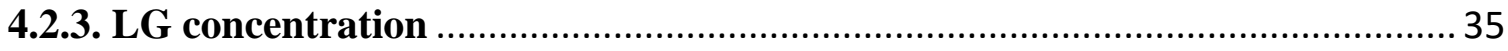

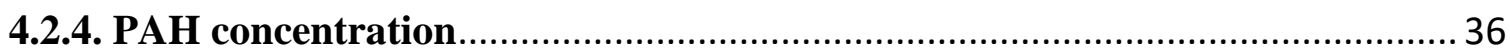

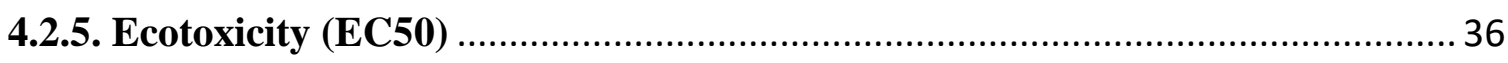

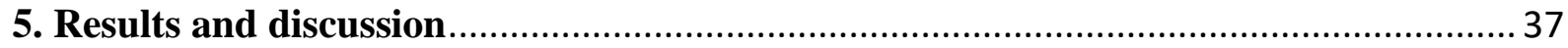

5.1. Generation and characterization of artificially generated carbonaceous particulate

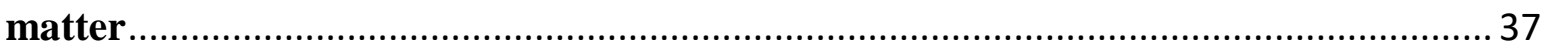

5.1.2. Measurement setup of the CPM generator ................................................. 38

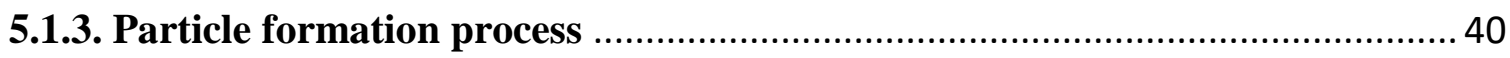


5.1.3. Characterization of the generated CPM in the function of generation

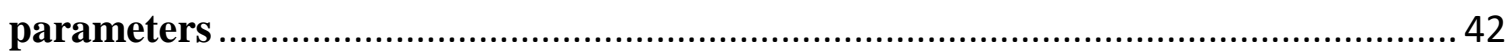

5.2. Investigation of diesel emitted carbonaceous particulate matter........................ 52

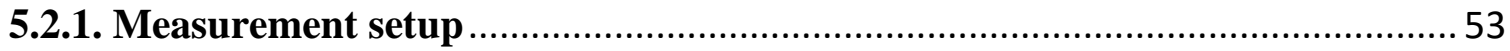

5.2.2. Dynamic changes at different engine operating conditions and fuel types...... 59

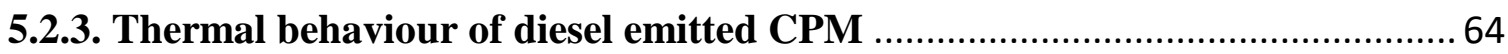

5.2.4 Morphology and microstructure of diesel emitted particles ........................... 71

5.3. Correlations between the physical, chemical and toxicological properties of atmospheric carbonaceous particulate matter........................................................ 74

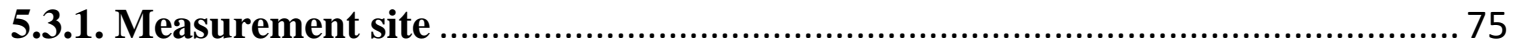

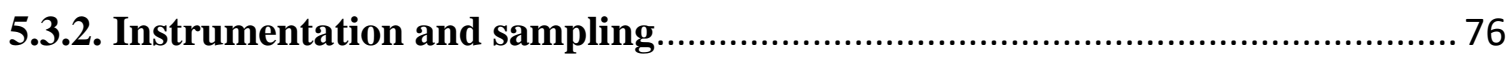

5.3.3. Diurnal variation of the measured parameters …........................................ 77

5.3.4. Correlation between the measured parameters ............................................ 83

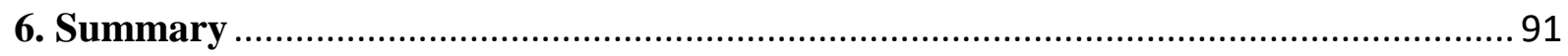

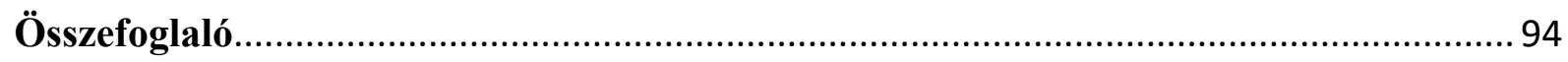

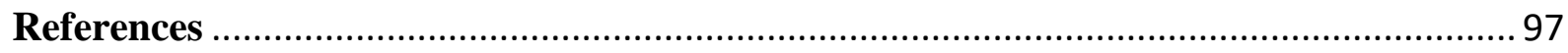

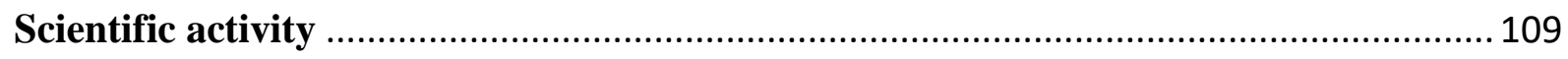

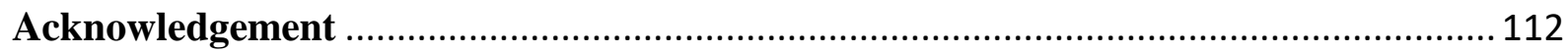




\section{AbBreviations}

\begin{tabular}{|c|c|}
\hline CPM & carbonaceous particulate matter \\
\hline 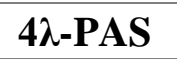 & four wavelength photoacoustic spectrometer \\
\hline AAE & Absorption Angström Exponent \\
\hline BC & black carbon \\
\hline BrC & brown carbon \\
\hline BTEX & benzene, toluene, ethylbenzene, xylen \\
\hline CFC & chlorofluorocarbon \\
\hline CMD & count median diameter \\
\hline CPC & Condensation Particle Counter \\
\hline CVS & constant volume sampling \\
\hline DM & difference method \\
\hline DMA & Differential Mobility Analyzer \\
\hline DMS & dimethyl-sulphide \\
\hline DOC & diesel oxidation catalyst \\
\hline DPF & diesel particulate filter \\
\hline DPM & diesel emitted carbonaceous particulate matter \\
\hline EC & elemental carbon \\
\hline EC50 & $50 \%$ effective concentration \\
\hline ED & electron eiffraction \\
\hline EGR & exhaust gas recirculation \\
\hline EPA & Environmental Protection Agency (USA) \\
\hline $\mathbf{E U}$ & European Union \\
\hline FAME & fatty acid methyl ester \\
\hline GDP & gross domestic product \\
\hline GHG & greenhouse gas \\
\hline GSD & geometric standard deviation \\
\hline HCFC & hydrofluorocarbon \\
\hline HRTEM & $\begin{array}{l}\text { high-resolution transmission electron } \\
\text { microscopy }\end{array}$ \\
\hline HULIS & humic-like substance \\
\hline IR & infrared \\
\hline IT & information technology \\
\hline $\mathbf{K r F}$ & Krypton Fluoride \\
\hline LAC & $\begin{array}{l}\text { light absorbing carbonaceous aerosol } \\
\text { component }\end{array}$ \\
\hline LG & levoglucosan \\
\hline MAC & mass specific optical absorption coefficient \\
\hline MD & mineral dust \\
\hline NDIR & Non-Dispersive Infrared Detector \\
\hline OAC & optical absorption coefficient \\
\hline OC & organic carbon \\
\hline
\end{tabular}




\begin{tabular}{cc}
\hline OPC & Optical Particle Counter \\
\hline PA & photoacoustic spectroscopy \\
\hline PAH & polycyclic aromatic hydrocarbon \\
\hline PAS & photoacoustic spectrometer \\
\hline PLD & pulsed laser deposition \\
\hline PM & particulate matter \\
\hline ROS & reactive oxygen species \\
\hline SD & size distribution \\
\hline SMPS & Scanning Mobility Particle Sizer \\
\hline TC & total carbon \\
\hline TD & thermodenuder \\
\hline TEM & Transmission Electron Microscopy \\
\hline TEOM & Tapered Element Oscillating Microbalance \\
\hline TNC & total number concentration \\
\hline TVC & total volume concentration \\
\hline UV & ultraviolet \\
\hline VIS & visible \\
\hline VOC & volatile organic compounds \\
\hline WHO & World Health Organization \\
\hline WSOC & water-soluble organic carbon \\
\hline
\end{tabular}




\section{INTRODUCTION}

Atmospheric aerosol is in the focus of scientific interest due to its impact on climate human health as well as issues related to its legal regulation (Andreae and Ramanathan, 2013; IPCC, 2013; Dockery and Pope, 1996). Airborne particles can force climate directly (scattering and absorbing solar radiation) and indirectly (participating in cloud formation processes). Direct scattering of solar radiation has cooling (negative forcing) while absorption has heating impact (positive forcing). Recently, more and more attention has been focused on carbonaceous particulate matter (CPM) and especially on its light absorbing fraction. Light absorbing carbonaceous aerosol components (LAC) have the second highest positive radiative forcing following $\mathrm{CO}_{2}$ (Bond et al., 2013). Radiative forcing by aerosol is estimated with huge uncertainty (Penner et al., 2001; Schwartz, 2004; Lack et al., 2006; Solomon et al., 2007). Indirect (cloud) forcing associated to aerosols is currently the largest factor of uncertainty in climatic models (Smith and Bond, 2014).

Uncertainty generally arises from two factors. Firstly, inherent properties of carbonaceous particles are primarily determined by the initial burning conditions and fuel type. Secondly, aerosol properties are significantly affected by physical and chemical interactions between aerosol particles and their ambience. These processes are generally referred to as atmospheric aging. Therefore, interpretation of data acquired during immission measurements is still limited. Simultaneous measurement of aerosol parameters utilizing combined online and offline methods among well-controlled laboratory circumstances and at various field locations could decrease limitations. Another difficulty is the lack of a generally accepted reference material that can model the complex properties of atmospheric CPM (Baumgardner et al., 2012; Gysel et al., 2011). There are instruments that can provide model carbonaceous aerosol that mimic the properties of fossil fuel and biomass burning emitted aerosol (Moore et al., 2014; Helsper et al., 1993). However, neither makes it possible to investigate the most relevant CPM properties independently from each other in the function of factors influencing particle formation.

To further improve the accuracy of climate models, the spectral characteristics of atmospheric aerosol including optical absorption and scattering must be measured with appropriate accuracy. While technological solutions for measuring light scattering by aerosol are widely available, measurement of optical absorption is more challenging by nature (Charlson and Heinzenberg, 1996; Andreae and Gelencsér, 2006). Optical absorption cannot be 
detected directly as during absorption photons are converted to thermal energy. Per that, issues of instrumentation can also result in additional uncertainty. The most broadly applied methodologies for measuring light absorption by aerosol are the difference method (DM), the filter-based method and photoacoustic spectroscopy (PA) (Horvath, 1993; Andreae and Gelencsér, 2006). Application of the DM is limited during events with high pollution (Lack et al., 2014), while instruments operating with the filter-based method require measurement site and aerosol composition-specific correction (Liousse et al., 1993; Petzold et al., 1997; Ballach et al., 2001; Arnott et al., 2005). Photoacoustic spectrometers (PAS) are among the most widespread used instruments that measure light absorption of atmospheric aerosol in their natural suspended form (Andreae, 2001). The recent availability of multi-wavelength PAS opens novel possibilities for the more precise and accurate measurement of optical absorption in the whole climate-relevant spectral range under real ambient and model laboratory conditions as well (Arnott et al., 2005, Ajtai et al., 2010b, Ajtai et al., 2011; Schmid et al., 2006; Utry et al., 2014, Linke et al., 2016; Pinter et al., 2017; Smausz et al., 2017; Pinter et al., 2018).

Urban CPM dominantly originates from various anthropogenic emission sources. During the winter, traffic and household burning (mostly for heating) were found the be the most significant sources of emission (Sandradewi et al., 2008a, b; Favez et al., 2009; Favez et al., 2010; Ajtai et al., 2015, Salma et al., 2017). Diesel emitted carbonaceous particulate matter (DPM) is classified as carcinogenic to humans by the World Health Organization (WHO) (IARC, 2012). DPM has also recently been found to have a significant ecotoxicological impact as well (Lin and Chao, 2002; Papadimitriou et al., 2008; Vouitsis et al., 2009). Increasing diesel engine standards and diesel exhaust aftertreatment systems like diesel particulate filter (DPF), exhaust gas recirculation (EGR) and diesel oxidation catalysts (DOC) are expected to decrease associated health risks. As opposed to that the toxicological nature of emission from domestic burning has only been getting recognized recently (Muala et al., 2014; Sigsgaard et al., 2015). Working out solution strategies for regulating domestic particulate emission is still a challenge to be faced in the future.

I joined MTA-SZTE Research Group on Photoacoustic Spectroscopy in 2011 as a graduate student. Aerosol laboratory of the research group and adjunct scientific infrastructure of the University of Szeged Faculty of Natural Sciences and Informatics provides a unique opportunity for in the investigation of the complex physical and chemical features of atmospheric and artificially generated carbonaceous aerosol even on an international level. 


\section{THEORETICAL BACKGROUND}

\subsection{ATMOSPHERIC CARBONACEOUS AEROSOL}

In general, aerosol is a system of colloidal liquid and/or solid particles dispersed in gas. In case of atmospheric carbonaceous aerosol or in other words carbonaceous particulate matter (CPM), gas medium is ambient air. Carbonaceous aerosol forms during incomplete combustion of fossil fuels or biomass. The most dominant anthropogenic sources are traffic, industry and household burning, however it can originate from volcanic activity, forest wildfires as well as biogenic processes. (Bond et al., 2013; Karagulian et al., 2015).

Based on the circumstances of formation, we distinguish between primary and secondary particles. Primary particles are directly emitted into the atmosphere while secondary particles are formed during atmospheric nucleation and condensation processes. Primary emitted natural carbonaceous aerosol particles can be bacteria, viruses, pollen, volcanic aerosol and suspended soil-related components (e.g. Humic-Like Substances (HULIS)). Anthropogenic carbonaceous particles originate from traffic, household heating and industrial combustion processes. Secondary carbonaceous aerosol is formed from gaseous precursors (alkanes, alkenes, aromatic and carbonyl compounds as well as VOCs) emitted by either natural or anthropogenic sources (Finlayson-Pitts and Pitts, 2000).

The most important parameters describing CPM like size, morphology, chemical composition and the optical properties of atmospheric carbonaceous aerosol are primarily determined by the conditions of combustion. Carbonaceous aerosol components can be selectively identified based on various parameters like thermochemical and optical properties as well as molecule structure using relevant instrumentation methods (Fig. 1.) (Pöschl, 2003). It is important to point out that there is no direct compliance between the different nomenclatures shown in Fig.1. Carbonaceous particles with graphitic molecular structure and high thermal stability can fulfil requirements of being classified as EC, however they are not necessarily BC based on their optical response. Matter of fact, there are no universal and absolute definitions for the different carbonaceous aerosol types, although there is high correlation between properties determined by distinct methodologies among various measurement conditions (Petzold et al., 2013). Sufficient characteristics for classifying various light absorbing CPM components are detailed in Section 2.3. with respect to inherent particle properties. 
In addition, identifying different carbonaceous aerosol species in ambient imission is a challenge as combustion emitted particles are largely modified during atmospheric aging processes as well (Zhang et al., 2008; Moore et al., 2014).

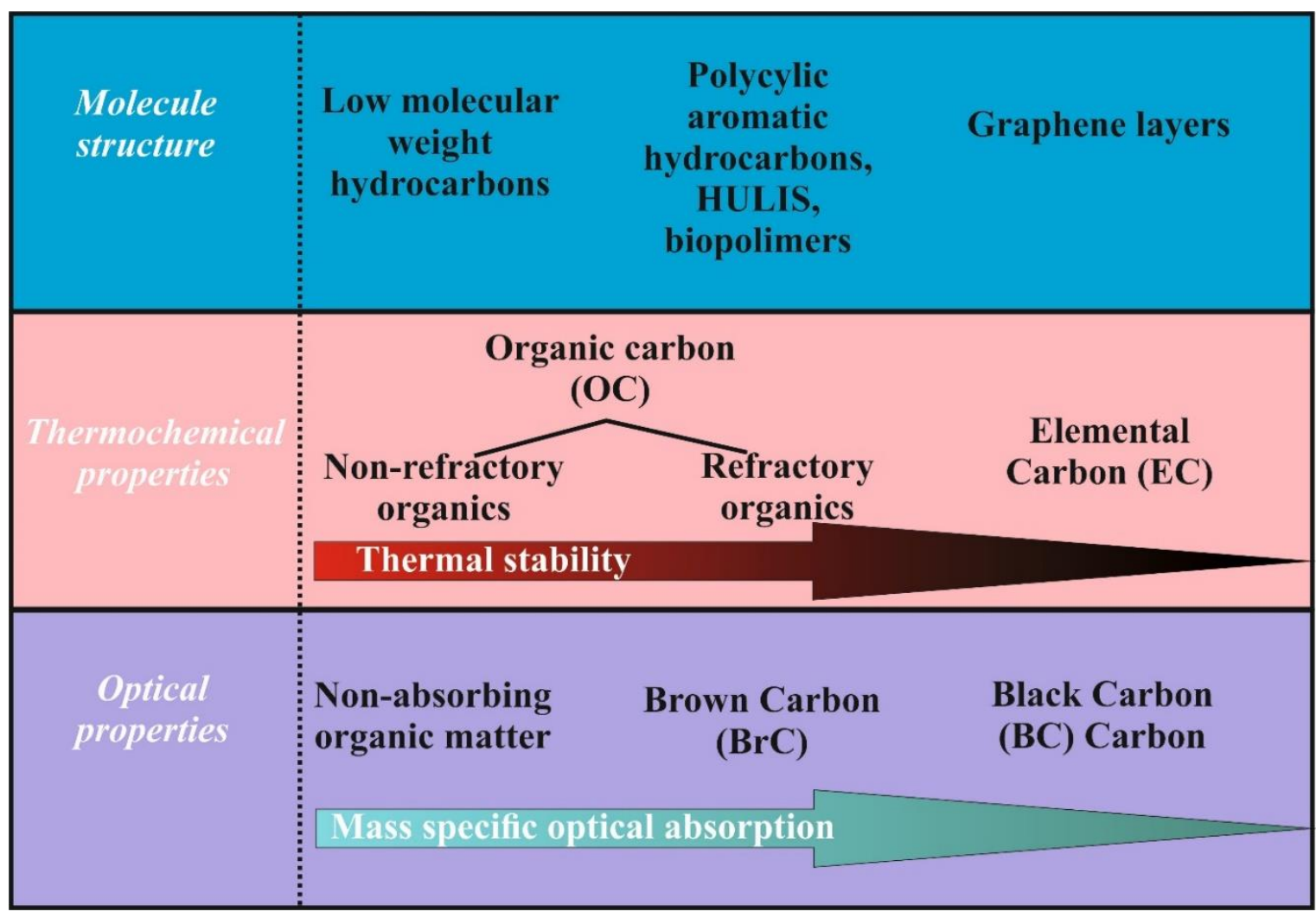

Fig.1. Carbonaceous aerosol types categorized based on molecule structure, thermochemical and optical properties, respectively (based on Pöschl, 2003).

In the next section I describe the importance of studying CPM. The most important CPM characteristics are to be discussed in Section 2.3. in detail, while measurement methods I applied for studying these properties is discussed in Section 4. 


\subsection{SIGNIFICANCE OF ATMOSPHERIC CARBONACEOUS AEROSOL}

\subsubsection{Climatic IMPaCt}

The composition of the atmosphere has been impacted by human activities during history in several ways. Human-related emission of atmospheric agents like $\mathrm{CO}_{2}, \mathrm{CH}_{4}, \mathrm{O}_{3}, \mathrm{NO}_{2}$, chlorofluorocarbons (CFCs) and hydrofluorocarbons (HCFCs) called together greenhouse gases (GHG) and aerosols have had significant impact on the energy balance of the Earth and the atmosphere (Bolin and Doos, 1989). Gradual increase of the concentration of GHGs has been contributing to positive radiative forcing (warming) of the atmosphere (Smith and Bond, 2014). GHG forcing is expected to increase further in the future (Smith and Bond, 2014) In contrast with GHGs, atmospheric aerosol particles can both scatter and absorb solar radiation consequently they can impact radiative forcing in both negative (cooling effect) and positive way (heating effect), respectively (direct climatic impact). Aerosol particles have further climatic impact by participating in cloud forming processes as condensation nuclei (indirect effect). Historical pattern-matching studies have shown that considering the complex climatic of aerosols is crucial in explaining global and regional temperature change patterns (Santer et al., 1995).

In the past, atmospheric aerosols were estimated to have net negative forcing. They were even thought to compensate positive radiative forcing by GHGs that was ironically named the Whitehouse effect (Schwartz, 1996). It was only later discovered that light absorbing aerosol components, black carbon (BC), brown Carbon (BrC) and mineral dust (MD) have considerable positive radiative forcing (Bond et al., 2013). Due to the large temporal and spatial variation of aerosol emission and accordingly atmospheric aerosol composition, radiative forcing caused by historical and present aerosol emissions is assessed with huge uncertainty (Smith and Bond, 2014; Kiehl, 2007; Schulz et al., 2006). What is more, indirect aerosol (cloud) forcing is estimated with the highest uncertainty in climatic models of our time (Smith and Bond, 2014).

Another problem is that different models are quite difficult to compare. They can vary in investigated components and in the time range of forcing projections as well. Smith and Bond, 2014 have recently reviewed radiative forcing by the three most essential aerosol species of mostly anthropogenic origin (BC, organic carbon (OC) and sulphate aerosol) (Smith and Bond, 2014). They considered the results of an abundance of relevant climatic models based on historical and future emission trajectories. For year 2000, BC was estimated to have mayor positive radiative forcing (between 0.23 and $0.57 \mathrm{Wm}^{-2}$ with a medium value of $0.4 \mathrm{Wm}^{-2}$ ). OC and sulphate aerosol are assessed to have a net negative forcing (between -0.11 and $-0.025 \mathrm{Wm}^{-}$ 
${ }^{2}$ with a medium value of $-0.056 \mathrm{Wm}^{-2}$ and between -0.6 and $-0.2 \mathrm{Wm}^{-2}$ with a medium value of $-0.4 \mathrm{Wm}^{-2}$, respectively). Indirect forcing by aerosol through formation of clouds is estimated to be negative $\left(-0.7 \mathrm{Wm}^{-2}\right)$, although constrained within the highest uncertainty range (between -1.2 and $-0.3 \mathrm{Wm}^{-2}$ ). While sulphate aerosol emission has been gradually declining due to regulations since the $1970 \mathrm{~s}, \mathrm{BC}$ emission is expected to peak in the middle of the $21^{\text {st }}$ century between 0.25 and $0.7 \mathrm{Wm}^{-2}$ with a medium value estimated be around $0.7 \mathrm{Wm}^{-2}$ (Klimont et al., 2013; Masui et al., 2011; Riahi et al., 2011; van Vuuren et al., 2011; Smith and Bond, 2014).

Based on emission projection scenarios, the climatic role of atmospheric CPM is thought to be significant until the end of the $21^{\text {st }}$ century (Smith and Bond., 2014). After that radiative forcing by GHGs is to be dominant relative to CPM due to their continual atmospheric accumulation (Riahi et al., 2011; Thomson et al, 2011). However, CPM forcing is projected to be higher in 2100 than the preindustrial level. Implementation of climate policies targeting global CPM emission could even speed up this process (Thomson et al., 2011).

\subsubsection{TOXICOLOGICAL IMPACT}

The link between air pollution and human diseases has been recognized since ancient times. However, air quality became a major global issue only in the $20^{\text {th }}$ century thanks to several infamous air pollution events. Thousands of people died during the course of a few days in 1930 due to $\mathrm{SO}_{2}$ pollution emitted by a local factory in the Meuse Valley, Belgium (Nemery et al., 2001). The most well-known event related to air pollution is probably the London smog of December 1952. Dense fog mixed with smoke-related particles descended upon the city resulting in more than 12,000 excess deaths until February 1953 (Bell and Davis, 2001).

PM emission has been shown to pose a serious risk both to human health and earthly ecosystems. Exposure to PM can cause various human health effects including increased hospital admission, pulmonary malfunctions, respiratory symptoms, cardiovascular diseases and premature deaths (Dockery et al., 1993; Schwartz et al., 1994; Pope et al., 2002, Czövek et al., 2012; Longhin et al., 2016; Landkocz et al., 2017). Guaita et al., 2011 showed that high particle concentration levels can initiate low birth weight in infants, pre-term deliveries and presumably fetal and infant deaths. Significant relationship was found by McCormack et al., 2011 between PM levels and asthma symptoms among children aged 2 to 6 years old. Bell et al., 2008 showed that even short-term exposure to PM can lead to increased cardiovascular and respiratory hospital admissions. Moreover, a U.S. national epidemiological study found strong and persistent correlation between adult diabetes and particulate pollution (Pearson et al., 2010). 
Particle are likely to deposit in different regions of the respiratory system based on their size (Fig. 2.). Coarse aerosol particles are called PM10, particles under $2.5 \mu \mathrm{m}$ are classified as the breathable or fine fraction of PM (PM2.5), while particles below $0.1 \mu \mathrm{m}$ (PM0.1) are also called the ultrafine fraction of PM. Particles with a dimeter larger than $10 \mu \mathrm{m}$ are filtered by the nose and the upper airway. Coarse particles (PM2.5-10) can penetrate the lung, whereas the fine fraction (PM2.5) can reach the alveoli (Anderson et al., 2012). As a result of that, fine particles can get into the blood stream and transported to any internal organ including the brain (Valavanidis et al., 2008).

Aerosol particles can act as transporters of toxic agents as they are likely to absorb various carcinogenic and mutagenic constituents like polycyclic aromatic hydrocarbons (PAH) as well as heavy and transition metals (Hayakawa et al., 1995; Schnelle-Kreis et al., 2001; Kawanaka et al., 2002). Transitions metals increase the production of reactive oxygen species (ROS) causing cellular and tissue damage (Aust et al., 2002; Hitzfeld et al., 1997; Donaldson et al., 2002; Li et al., 2009).

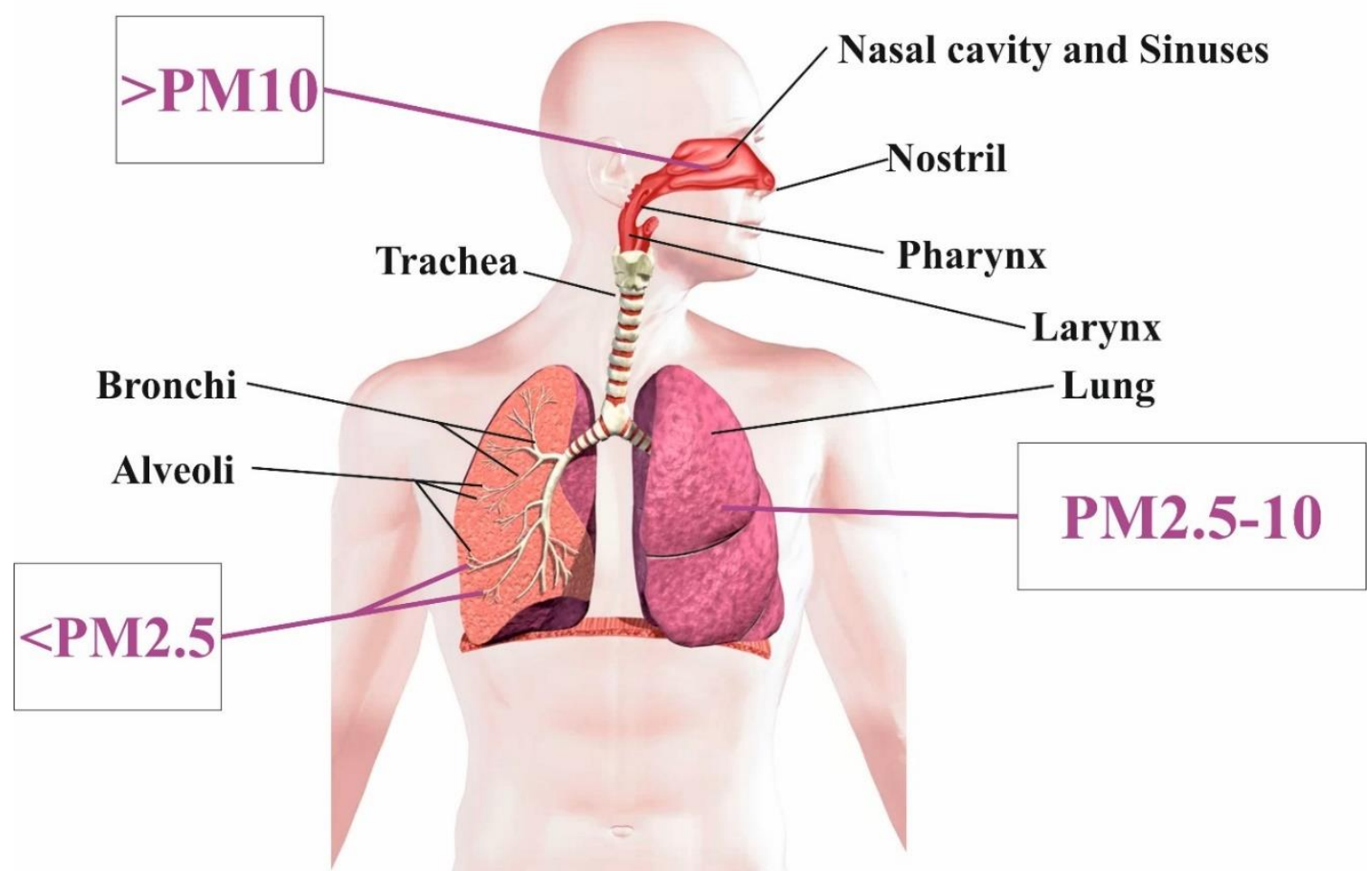

Fig. 2. Deposition of aerosol particles in the human respiratory system (Photo credit by Leonelli Calletti (shutterstock.com)

PM related diseases have considerable negative economic impacts as well. Patients with PM-related diseases and their families suffer welfare losses that can considerably affect gross 
domestic product (GDP) in certain cases (Chen et al., 2010; Hou et al., 2011, 2012). In 2009, China was estimated to have suffered 106.5 billion USD economic loss due to PM-related health effects (Hou et al., 2012). Consequently, tackling air pollution is a strategic issue in developing countries.

Diesel exhaust is ranked as carcinogenic to humans by the World Health Organization (WHO) (IARC, 2012). Diesel emitted carbonaceous particulate matter (DPM) has also been shown to be ecotoxic (Lin and Chao, 2002; Papadimitriou et al., 2008; Vouitsis et al., 2009). Improving automotive engine standards, modern diesel engines being equipped with exhaust post-treatment devices like EGR (Exhaust Gas Recirculation) and DPF (Diesel Particulate Filter) units are expected to provide solution for decreasing the health risks of DPM. As opposed to that, CPM pollution by residential sources (household and open burning) is a challenge to be faced in the future.

\subsubsection{LEGAL REGULATION}

The most important directive regulating air quality in the European Union (EU) is 2008/50/EC amended with 2015/1480/EC. Particulate emission (PM10 and PM2.5) are categorized as pollutants with the highest risk on human health. Accordingly, strict regulations as well as requirements for monitoring, transition of data were issued. Determination of limit, obligation and target values for PM2.5 appeared as new element in the Directive. PM2.5 exposure was targeted to be decreased by $10 \%$ by 2020 compared to 2010 levels. In case a country cannot fulfil requirements, infringement procedure is launched by the European Commission. Infringement procedure was launched against Hungary in July 2010 due to exceeding of PM10 limit value in succession. The situation in Hungary has not improved appreciably since then. Year 2017 produced a record-breaking winter regarding air pollution. As a result of the prevalent exceeding of limit value, environmental secretaries of 9 member countries including Hungary were summoned by the European Commission in January 2018. If the necessary counter measures are not implemented, a new infringement procedure is to be launched by the European Commission.

In Hungary, Government Decision 1330/2011. (X.12.) contains regulations for decreasing PM10 emission. It defines an Action Plan aimed to fulfil proper air quality according to level values of pollutants defined by Ministry of Rural Development Regulation no. 4/2011. (I. 14.). Limit values for PM10 are $40 \mu \mathrm{g} / \mathrm{m}^{3}$ (yearly) and $50 \mu \mathrm{g} / \mathrm{m}^{3}$ (daily) that can be exceeded 35 times a year at most. Special regulations regarding PM2.5 must also be fulfilled (target value: 
$25 \mu \mathrm{g} / \mathrm{m}^{3}$ by year 2015 , exposure concentration obligation: $20 \mu \mathrm{g} / \mathrm{m}^{3}$ ). If PM10 concentration exceeds alert threshold value $\left(100 \mu \mathrm{g} / \mathrm{m}^{3}\right)$ for two days in a row and according to meteorological forecast no improvement is expected, smog alert is announced. Although most studies show that in Central-Europe and most importantly in Hungary, the residential sector is among the three most important sources of emission besides traffic and industry (Karagulian et al., 2015; Salma et al., 2017), current regulation does not provide solution for decreasing air pollution from that sector. According to current regulation, in case of smog alert, traffic is restricted. Vehicles of certain environmental categories are banished from the roads. Also, open burning of litter and domestic waste is prohibited. Developing standardized particulate matter source apportionment methods could really improve the efficiency of clean air policies. In accord with that, the Action Plan implemented in Government Decision 1330/2011. (X.12.) names source apportionment as one of its major goals. 


\subsection{PARAMETERS DESCRIBING ATMOSPHERIC CARBONACEOUS PARTICULATE MATTER}

As discussed in the previous section, light absorbing CPM components can be characterized based on various properties. In this section I am describing the most important characteristics and their consequences.

\subsubsection{SIZE DISTRIBUTION}

The size of an aerosol particle is generally described with an equivalent diameter based on various measuring methods. Aerodynamic diameter is the diameter of a unit density spherical particle with equal settling velocity than that of the investigated particle. Aerodynamic diameter is only applicable for describing particles above $0.5 \mu \mathrm{m}$. Under that threshold size, particles carry out Brown movement and can be characterized with the so-called diffusion diameter. Diffusion diameter of a particle means that the diffusion velocity of the investigated particle is the same than that of an equivalent diameter spherical particle of unit density. The most generally used equivalent diameter to describe submicron aerosol particles is the mobility diameter. Mobility diameter means that the investigated particle of a certain size has an equivalent electric mobility than a unit density spherical particle of the same size. The size of atmospheric aerosol particles varies between a few nm up to $100 \mu \mathrm{m}$ ( 4 orders of magnitude). This is an extremely large scale if we consider the fact that that 1 billion $1 \mathrm{~nm}$ spherical particles make for the mass of a single $1 \mu \mathrm{m}$ particle.

As it is not possible to determine the exact size of every single particle in a unit volume of ambient air (up to $10^{6}-10^{7}$ particles in $\mathrm{cm}^{3}$ ), the whole possible size range can be divided to narrower subdivisions (so-called called size bins) and the number concentration of particles is determined in each bin. The sum of particle concentrations in each bin adds up to total number concentration. Size distribution is most generally plotted on a logarithmic scale as particle size variates on a four orders of magnitude wide scale. Otherwise, the number of smaller particles is difficult to read from the graph. The most universal representation of the size distribution of ambient aerosol is the so called $\mathrm{dN} / \mathrm{d} \log \mathrm{Dp}$ representation. Here measured number concertation $(\mathrm{dN})$ is divided with the width of each measured size bin, before plotted in the function of logarithmic particle size (Eq. 1).

$\frac{d N}{d \log D_{p}}=\frac{d N}{\log D_{p, u}-\log D_{p, l}}$

where $\mathrm{d} N$ is particle concentration, $D p$ is midpoint particle diameter, $D p, u$ is upper channel diameter, $D_{p, l}$ is lower channel diameter. 
This way the area of the size distribution curve is proportionate to the total number concentration of measured aerosol particles.

Aerosol size distributions are most generally characterized by statistics based on lognormal distributions (Heitzenberg, 1994). Interestingly, the lognormal nature of ambient aerosol SD is a purely empirical observation. There is no real theoretical reason behind atmospheric aerosol displaying lognormal size distribution, however it is simply the best fit (Zender, 2002). The lognormal fitting algorithm is based on Eq. 2.

$n_{n}(D)=\frac{N_{0}}{\sqrt{2 \pi} D \sigma_{g}} e^{-\frac{1}{2}\left(\frac{\left[\ln \left(\frac{D}{D_{n}}\right)\right]^{2}}{\sigma_{g}}\right)}$

where $n_{n}(D)$ is the lognormal size distribution function, $\mathrm{D}$ is size diameter, $D_{n}$ is count median diameter, CMD, $N_{0}$ is TNC of particles per volume, $\sigma_{g}$ is geometric standard deviation (GSD).

The statistical description of size distribution is based on the values listed in Eq. 2. Geometric mean diameter (GMD) applied in case of normal distributions is equal to count median diameter (CMD) at lognormal distributions (Eq. 3.).

$G M D=C M D=\left(D_{1}^{n_{1}} D_{2}^{n_{2}} D_{3}^{n_{3}} \ldots . D_{n}^{n_{N}}\right)^{\frac{1}{N}}$

where $G M D$ is geometric mean diameter, $C M D$ is count median diameter, $D_{i}$ is midpoint particle size, $n_{i}$ is number of particles in group $i$ having a midpoint size of $D_{i}$ and $N$ is total number of particles including all intervals (bins).

As in case of lognormal distributions, the $\log$ of particle diameter is normally distributed, the width of the SD curve is characterized with the standard deviation of the logarithms called GSD or $\sigma_{g}$ (Eq. 4).

$\log \sigma_{g}=\left[\frac{\sum n_{i}\left(\log D_{i}-\log D_{g}\right)^{2}}{N-1}\right]^{\frac{1}{2}}$

where $\sigma_{g}$ is geometric standard deviation, $D_{i}$ midpoint particle diameter of the $i^{\text {th }}$ bin, $n_{i}$ is number of particles in group $i$ having a midpoint size of $D_{i}$ and $N$ is total number of particles including all intervals (bins).

Atmospheric aerosol particles are categorized into for major size modes based on their characteristics size. Particles with a diameter (d) under $10 \mathrm{~nm}$ belong to the nucleation mode, 
particles with $\mathrm{d}$ between 10 and $100 \mathrm{~nm}$ belong to the Aitken mode, the accumulation mode is composed of particles with d between 100 and $1000 \mathrm{~nm}$, while even bigger particles account for the coarse size mode. Characteristic size modes of atmospheric aerosol, their composition as well as transition processed between them are plotted in Fig. 3.

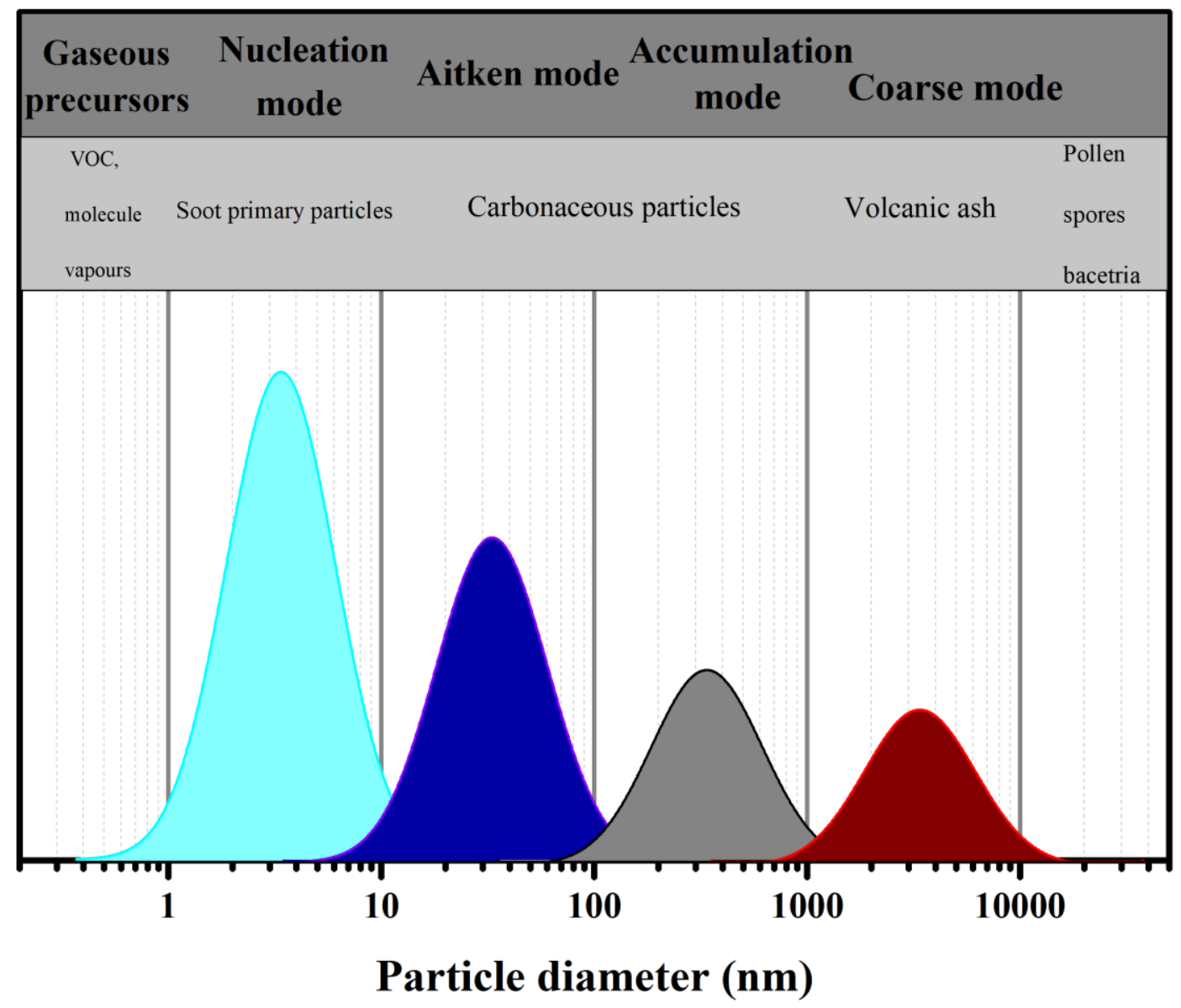

Fig. 3. CPM size modes, their composition and transition processes

Each size mode is due to distinct formation processes. The nucleation mode is formed by the process of new particle formation (also called nucleation) as follows. Precursor gases have low water pressure among atmospheric conditions. In case they cannot condensate on the surface of pre-existing aerosol particles, they are likely to form clusters with other molecules. If these clusters continue to grow until a certain threshold (nucleation threshold), new aerosol particles are formed (Curtius, 2006). Nucleation events have been observed among diverse atmospheric conditions (Kulmala e tal., 2013; Salma et al., 2011). Carbonaceous primary particles also form by nucleation from molecules vaporized during combustion processes (Gelencsér, 2004). In that case nucleation is governed by the thermal evolution of the particle precursor constituents (for details see Section 5.1.3.). Particles in the nucleation mode can grow 
into the Aitken mode and the accumulation mode through condensation and coagulation processes, respectively. Carbonaceous particles emitted by combustion processes (internalcombustion engines, fuel burning or wildfires) are typical constituents in the Aitken and the accumulation modes. Coarse carbonaceous aerosol particles are emitted into the atmosphere through volcanic activity. Particles larger than $10 \mu \mathrm{m}$ are generally of biogenic origin (pollen, bacteria, viruses, etc.).

Size distribution is one of the key features describing atmospheric carbonaceous aerosol as it is closely related the source of emission, chemical composition, atmospheric lifetime as well as the health and climatic effects atmospheric aerosol (John, 2011).

\subsubsection{OPTICAL ABSORPTION AND ITS WAVELENGTH DEPENDENCE}

The encounter of electromagnetic radiation and aerosol particles can result in various possible interactions. When an aerosol particle is being irradiated, it can scatter, refract or diffract electromagnetic radiation. These interactions are in sum referred to as scattering as in case of light energy is not altered, only the vector of spreading changes. The most abundant scattering mechanism between atmospheric particles and light is inelastic scattering during which the wavelength in incident light remains unchanged (Redmond et al., 2010). In case of optical absorption, excitation energy or a certain portion of it is absorbed by the irradiated particle and transferred into thermal energy that is subsequently released into the environment. The sum of optical absorption and scattering is called optical extinction $\left(\alpha_{\mathrm{ext}}=\alpha_{\mathrm{sca}}+\alpha_{\mathrm{abs}}\right)$ defined by the Beer-Lambert law (Eq. 5.)

$$
I=I_{0} e^{\left(-a_{e x t} c l\right)}
$$

where $I_{0}$ and $I$ are the intensity of incident and traversing light, respectively, $c$ is aerosol concentration and $l$ length of light path within the aerosol assembly.

The optical properties of atmospheric aerosol particles depend on their size, morphology and the chemical composition. Aerosol optical properties directly affect their climatic impact and carry information regarding emitting sources as well (Sandradewi et al., 2008ab; Seinfeld \& Pandis, 2006).

Aerosol with distinct chemical composition can also be distinguished based on the wavelength dependence of their optical absorption described by the Absorption Angström Exponent (AAE) (Utry et al., 2014; Favez et al., 2009, Bergstrom et al., 2002). AAE is basically 
the slope of the linear fit of OAC plotted in the function of the wavelength of irradiation (both quantities plotted as logarithmic values) (Eq. 6.).

$\frac{O A C\left(\lambda_{1}\right)}{O A C\left(\lambda_{2}\right)}=\left(\frac{\lambda_{1}}{\lambda_{2}}\right)^{-A A E}$

where $\lambda$ is the wavelength of irradiation $\operatorname{OAC}(\lambda)$ is optical absorption coefficient measured at $\lambda$ wavelength.

Different carbonaceous aerosol fractions can be also discerned based on their optical absorption. Black Carbon (BC) has relatively high optical absorption in the IR-vis range. It can absorb up to $30 \%$ of incident solar radiation $\left(7.5 \mathrm{~m}^{2} / \mathrm{g} @ 550 \mathrm{~nm}\right.$ according to Bond and Bergstorm, 2006). Optical absorption by BC is proportional to the total volume of particles, so it only slightly depends on morphology. It is an inverse linear ratio to the wavelength of excitation, i.e. optical absorption increases linearly towards shorter wavelengths (AAE $\approx 1$ based on Eq. 6.). $\mathrm{BC}$ is the most important atmospheric aerosol constituent regarding its climatic impact with the second highest radiative forcing following $\mathrm{CO}_{2}$ (Bond et al., 2013; Smith and Bond, 2014). BC dominantly originates from anthropogenic sources like traffic and industry (including fossil fuel-based power plants). The average ratio of BC in PM2.5 mass is estimated to be $2 \%$ in rural background area (K-Puszta, Hungary) (Molnár et al., 1999), while 14\% in urban areas like Budapest and Helsinki (Salma et al., 2001; Viidanoja et al., 2002).

Organic carbonaceous components are generally regarded as scattering particles with negative radiative forcing (Smith and Bond, 2014). However, it has recently been discovered that certain OC components considerably absorb solar radiation in the UV-Vis spectral range (Andreae and Merlet, 2001; Kichstetter et al., 2004). The light absorbing fraction of OC is called Brown Carbon (BrC). As opposed to $\mathrm{BC}, \mathrm{BrC}$ has significantly lower optical absorption in the IR-Vis range, however its optical absorption increases in an accelerating pace towards the UV range (AAE $>1$ based on Eq. 6.). BrC has lower radiative forcing compared to $\mathrm{BC}$, however, it absorbs 7-19\% of solar radiation (Feng et al., 2013). BrC can originate from various anthropogenic and natural sources. Most important sources are residential burning for heating and cooking, open burning and forest wildfires (Smith and Bond, 2014; Chakrabarty et al., 2014). BrC constituents include humic-like substances (HULIS) (Limbeck et al., 2003; Hoffer et al., 2006), pyrolytic products from biomass burning (Lack et al., 2012) and tar balls formed during smouldering (Chakrabarty et al., 2010; Pósfai et al., 2004). The contribution of BrC to total PM mass has large temporal and spatial variation (Jacobson et al., 2000). In certain 
geographical regions $\mathrm{BrC}$ can give up to $90 \%$ of total aerosol mass (Jacobson et al., 2000; Chakrabarty et al., 2014; Lamarque et al., 2010). The global contribution of BrC to PM mass in three times higher than that of BC (Smith and Bond, 2014; Feng et al., 2013).

\subsubsection{THERMAL STABILITY}

Considering thermal stability, atmospheric carbonaceous aerosol can be divided into two categories: elemental carbon (EC) and organic carbon (OC). EC and OC. EC has an almost completely homogenous molecule structure made of $\mathrm{C}$ atoms interconnected with $\mathrm{sp}^{2}$ bonds. As a result of that EC has very high thermal stability, it only burns over around $650^{\circ} \mathrm{C}$ in the presence of oxygen. OC has lower thermal stability as it can be volatilized at lower temperatures in oxygen free atmosphere as well. Based on the temperature necessary for volatilization, OC can be further discriminated as non-refractory and refractory subdivisions. OC is composed of hundreds of different chemical species most of which are still unknown (Andreae and Gelencsér, 2003). Thermal stability is primarily determined by molecule structure: Nonrefractory organic aerosol particles consist of low molecule weight hydrocarbons, while refractory organic matter is composed of polycyclic aromatic hydrocarbons (PAH), biopolimers and the recently discovered humic-like substances (HULIS) found in the atmosphere.

\subsubsection{MoRPHOLOGY AND MiCROSTRUCTURE}

Carbonaceous aerosol particles are fractal-like chain aggregates made up of carbon spherules of a few $\mathrm{nm}$ up to $50 \mathrm{~nm}$. Primary particles typically have an onion-like (graphitic) structure where graphene layers are oriented parallel to the external outer surface (Petzold et al., 2013). The size of EC fractal aggregates chains typically ranges from a few nm to $1 \mu \mathrm{m}$. Their fractal dimension is typically around 2 in case of fresh particles while it can variety up to 3 in case of aged ones. They have large specific surface typically between $10-100 \mathrm{~m}^{2} \mathrm{~g}^{-1}$. As a result of that they have high capacity for adsorbing other atmospheric species. OC particles have very similar morphology, although they are not solely composed of $\mathrm{C}$ atoms, but can contain few thousand different types of organic substances as well. According to recent observations by Chakrabarty et al., 2014, carbonaceous particles formed during biomass burning can be much larger than EC fractal aggregates $(1-20 \mu \mathrm{m})$.

As microstructure determines both thermal stability and optical absorption response of carbonaceous aerosol constituents which means that the same component can be referred to considering both optical and thermochemical terminologies (light absorbing OC is called $\mathrm{BrC}$ while light absorbing EC can also be referred to as BC). Molecule structure of carbonaceous particles is most commonly determined with offline electron-microscopic imaging. 
Thermochemical characterization can be carried out by both online and offline methods (Moore et al., 20014; Lack et al., 2014).

In the next section motivation and scientific goals of the thesis are discussed. 


\section{SCIENTIFIC OBJECTIVES}

Conditions of formation and the type of fuel primarily determine the inherent properties of CPM. As ambient carbonaceous particles go through significant atmospheric aging, their apparent features measured in immission can be largely masked. Controlled laboratory generation of carbonaceous aerosol that model atmospheric CPM as well as investigation of their complex microphysical features in the function of fuel type and the conditions of formation could really improve reliability of immission measurements. Accordingly, it is highly relevant scientific goal of our time.

Under real ambient conditions, diesel exhaust cools down after leaving the tailpipe. During this cooldown, vaporous species with high molecular weight either condense on the surface of non-volatile soot particles (heterogeneous condensation) or form new individual volatile particles (nucleated condensation). Both processes take place until the thermally driven equilibrium state is reached at a given temperature. These phenomena can modify the chemical composition and the mixing state of the freshly emitted diesel particulates, thus the climatic and human health impacts of diesel emitted particulate matter (Cheng, 2013).

Nowadays, a growing number of studies focus on the investigation of the number concentration and size distribution of diesel emitted CPM. Direct tailpipe sampling can provide information regarding the effect of engine operating conditions. The climate and health relevant emission properties of the diesel emitted particulate matter can be modelled and investigated under controlled laboratory circumstances using a standard dilution chamber at atmospheric pressure and temperature (Burtscher, 2005). During dilution chamber measurements exhaust temperature is reduced approximately to ambient temperature. That way, the effect of initial dilution on particle formation and the mixing state of diesel exhaust can be investigated among well-controlled measurement conditions. Modern diesel engines are equipped with exhaust post-treatment devices like EGR (Exhaust Gas Recirculation) and DPF (Diesel Particulate Filter) units. These do not only reduce particle emission but substantially change the characteristics of the exhaust. Thus, the investigation of raw engine-out emission is essential from the point of view of fuel and engine development, and important to better understand the masking impact of these devices.

Among urban wintry conditions, the most dominate sources of urban CPM are traffic and domestic heating. Technological development triggered by strictening emission standards and legislation solutions have the potential to decreasing risks associated with traffic emission. 
As opposed to that issues of domestic CPM emission are to be solved in the future. Several studies have shown that emission from the residential sector has a higher toxicological potential than that of traffic. Today, the PM toxicity is determined by various offline methodologies that provide useful information with considerable time lag. This way, the efficiency of counteractions can be limited. Future air pollution strategies should take into consideration unique toxicological risks associated with emitting sources to efficiently tackle risks of PM emission. To do that, more research should be focused on developing novel methods for apportioning emitting sources and decreasing the response time of assessing the impact of CPM on both human health and earthly ecosystems.

My goal was to study size distribution, morphology and microstructure of artificially generated model as well as real diesel emitted CPM. I was aiming to investigate the impact of various conditions of formation and fuel types on the characteristics parameters of emitted CPM. My further goal was to study the correlations between the online measured optical absorption properties and the offline studied chemical and toxicological potential of urban CPM. With respect to that I was also aiming to assess the applicability of the AAE as a firstscreening indicator of CPM toxicity. Based on these, I assigned the following scientific tasks:

1. Characterization of the size distribution, morphology and microstructure of model carbonaceous aerosol particles generated by laser ablation of a high purity graphite sample in the function of generation parameters.

2. Investigation of the size distribution, total number and volume concentration as well as the morphology and microstructure of diesel emitted particulate matter in the function of engine operating conditions in case of blends of commercially available diesel and biofuels.

3. Studying the thermal evolution of diesel emitted particulate matter (the ratio of constituents with distinct thermal stability found in diesel exhaust) using in in-house developed thermal adsorption unit (thermodenuder).

4. Determining the diurnal variation of a wide range of parameters measured by offline and online methodologies describing atmospheric carbonaceous particulate matter and co-emitted gaseous constituents. Based on their diurnal variation, investigating the correlation between offline determined chemical and toxicological properties and online measured microphysical and spectral features of urban CPM. Assessing the possibility of first-screening the toxicological potential of CPM based online measurement of its spectral response. 


\section{EXPERIMENTAL METHODS}

Since the same instrumentation and methodologies are used in the presented projects, a separate chapter is devoted to describing their description and technical details. The microphysical features of aerosols including optical absorption, scattering and size distribution as well as the concentration of the most significant ambient gas constituents were determined by real time measurement techniques. For the offline investigation of morphology, microstructure, chemical composition and the toxicological potential of CPM, filter accumulated aerosol samples were used.

\subsection{ONLINE MEASUREMENTS}

\subsubsection{OPTICAL ABSORPTION}

The wavelength dependent optical absorption of aerosols was determined by the

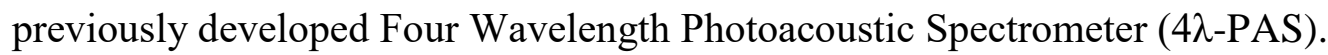

\section{$\underline{4-\lambda-P A S}$}

PA spectroscopy has been widely used both in gas and aerosol phase measurements on several scientific and industrial fields (Petzold and Niessner, 1996; Bozóki et al., 2011; Lewis et al., 2008; Flowers et al., 2010). As optical absorption by aerosol is in the focus of this paper, PA spectroscopy is only discussed here in respect of aerosol applications. The basic principle of aerosol phase photoacoustic signal generation is the following. An aerosol assembly dispersed in ambient air or another gaseous matrix is excited with a periodically modulated light source. Aerosol absorbs the incident electromagnetic radiation proportionally to its mass concentration and the absorption capacity in the Raleigh range which is typical for CPM. Excited particles release the absorbed energy to their environment (heat transfer) through thermal relaxation. This way, periodical temperature and pressure fluctuation (sound) occurs. The subsequent periodic changes of pressure can be detected by microphones, the photoacoustic signal is proportional to the mass concentration of absorbing aerosol. The mechanism of the photoacoustic effect is displayed in Fig. 4. 

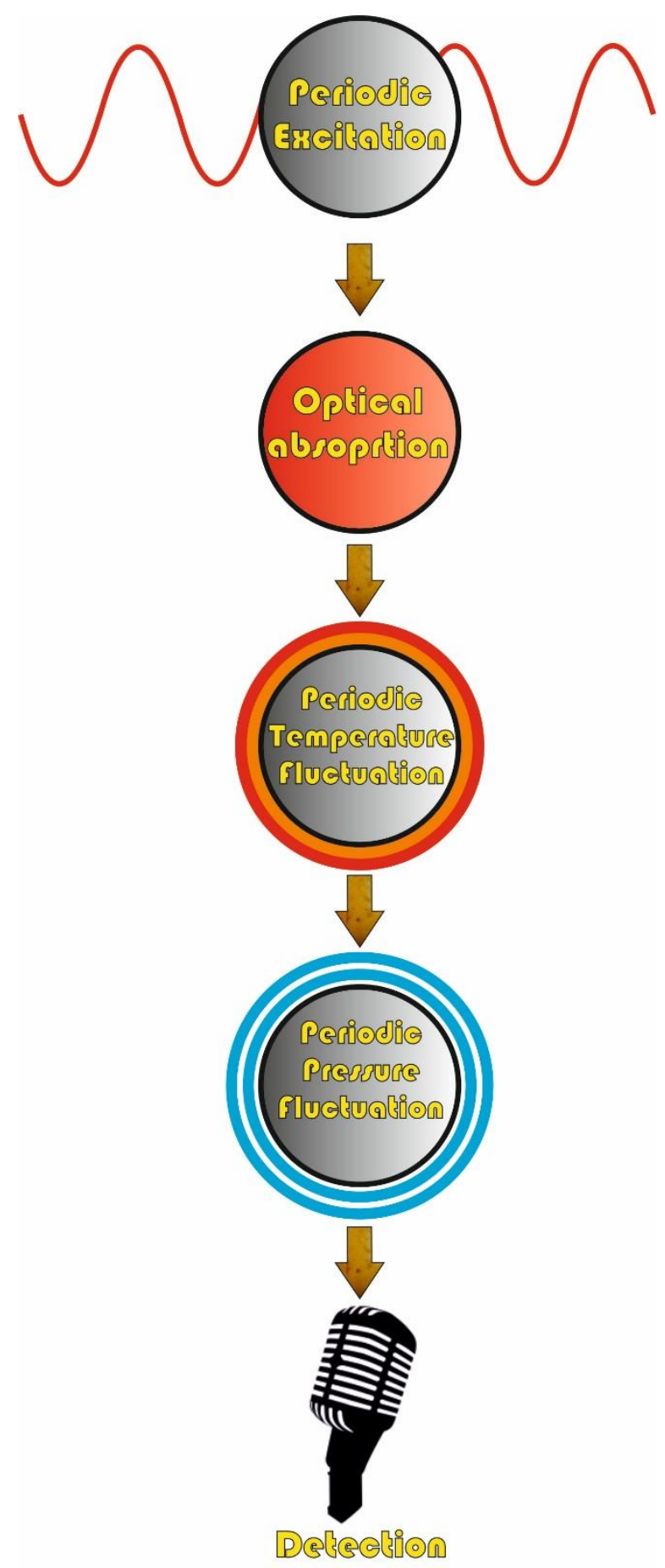

Fig 4. The PA effect

PA signal measured with a microphone is given based on Eq. 7.

$\left.P A=P \cdot M \cdot\left(C \cdot \sum_{i=1}^{n} \eta_{i} \cdot M A C_{i} \cdot c_{i}+A\right)\right)$

where $P A(\mathrm{~V})$ is the photoacoustic signal, $P(\mathrm{~W})$ is the power of the light source, $M\left[\mathrm{~V} \cdot \mathrm{Pa}^{-1}\right]$ is microphone sensitivity, $C\left[\mathrm{~Pa} \cdot \mathrm{m} \cdot \mathrm{W}^{-1}\right]$ is the constant describing the PA cell, $\eta$ is the efficiency of the PA signal generation, $M A C\left[\mathrm{~m}^{2} \cdot \mathrm{g}^{-1}\right]$ is the mass specific absorption of the measured 
substance, $c\left[\mathrm{~g} \cdot \mathrm{cm}^{-3}\right]$ is the concentration of the measured substance and $A\left[\mathrm{~Pa}^{-1} \mathrm{~W}^{-1}\right]$ is the background signal generated by components a different physical state than the substance to be measured (non-aerosol components).

Based on Eq. 7, to determine the optical absorption coefficient $\left[\mathrm{Mm}^{-1}\right](\mathrm{OAC}=\mathrm{MAC} \cdot \mathrm{c})$ of the measured aerosol, P, M, C, $\eta$ and A values must be known. P and A are monitored during PA measurements. $\mathrm{P}$ is continuously measured by light power meters, while $\mathrm{A}$ is semicontinuously determined by periodically drawning aerosol-free (filtered) carrier gas through the PA cells (Eq. 8). M·C· $\eta$ describes the sensitivity of the PA measurement system that can be determined by gaseous phase calibration (Eq. 7). The basic inherent features of the PA method regarding the measurement of light absorption by are the following:

High sensitivity: PA spectroscopy is a so called zero-background measurement technique (only the absorption generates PA signal) (Utry et al., 2014).

$>$ Insensitivity for light scattering: scattered light does not generate additional pressure contribution (Sharma et al., 2013).

$>$ Free from measurement artefacts associated with filter attenuation measurement methods: free floating (aerosol phase) sampling (no filter used) (Lack et al., 2006).

$>$ Gaseous phase calibration: the instrument is calibrated directly to optical absorption providing unique opportunity for the accurate measurement of light absorption by aerosol independently of its composition (Utry et al., 2014).

> High resolution sampling: small measurement chamber volume (Utry et al., 2014).

The technical details and the characteristic description of the in-house developed 4- $\lambda$ PAS (Fig. 5.) used in this study were described in detail in earlier studies (Ajtai et al., 2010a; Utry et al., 2014), only a brief explanation is given here. 


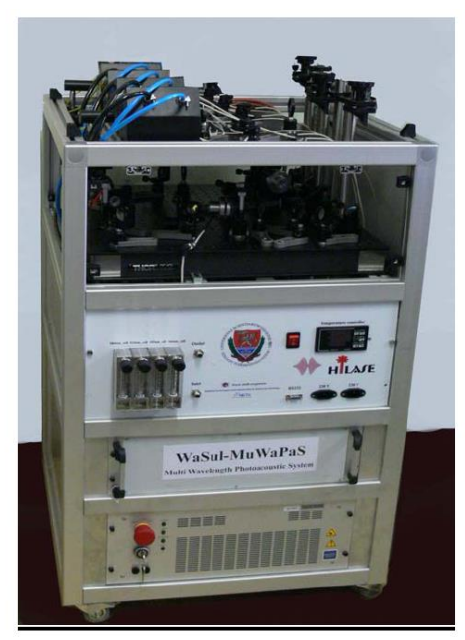

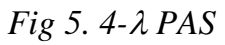

The multi-wavelength $(1064,532,355$ and $266 \mathrm{~nm})$ light source of the instrument is based on a diode pumped electro-optical Q-switched Nd:YAG OEM disc laser emitting at 1064 $\mathrm{nm}$ and its frequency converted higher harmonics. In measuring mode, all the light sources are directed parallel through 4 identical PA cells. In the applied PA cells, the resonator length is fitted to the fundamental longitudinal resonance frequency of the excitation being around $4 \mathrm{kHz}$ (Fig. 6.). In calibration mode, the second harmonics (532 nm) wavelength is led through each PA cell subsequently (Fig. 6.). The PA cells and the gas handling units were optimized for aerosol sampling considering particle losses (Utry et al., 2014).

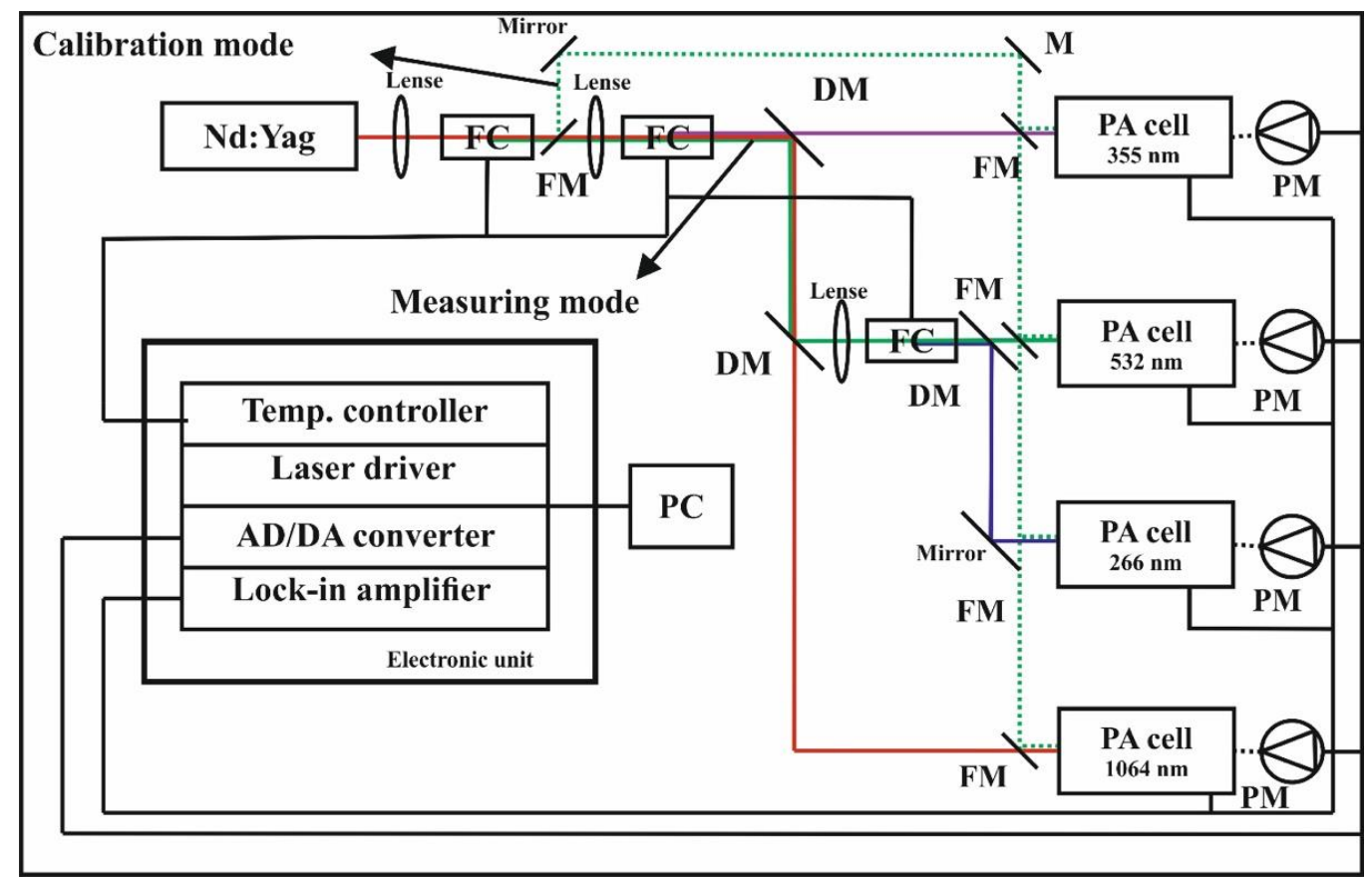

Fig. 6. Schematic view of the measurement and calibration operational modes of the 4- $\lambda$ PAS. (FC: frequency conversion; FM: flipping mirror; DM dichroic mirror; PM: power meter) 
PA cells of the instrument are calibrated with $\mathrm{NO}_{2}$ gas at 532nm (calibration mode). The $532 \mathrm{~nm}$ laser beam is led into the PA cells by flipping mirrors. Per that the calibration procedure is independent of composition and wavelength (Ajtai et al., 2010a). The accuracy of the instrument was proved to be below 2-6\% depending on the applied wavelengths (Ajtai et al., 2010a).

Background and signal measuring modes are switched by an automatically controlled magnetic valve. During the background measurement mode, gas stream is drawn through a Balston DFU particle filter, so only PA signal generated by the gas devoid of aerosol particles is measured. That way, gaseous cross effects can be eliminated by the background correction protocol described by Ajtai et al., 2010a and a supplementary specially designed active carbon filter built into the sampling system of the instrument (Thermo Scientific ${ }^{\mathrm{TM}}$ ChemComb 3500 filter cartridge, honeycomb denuder). 


\subsubsection{SIZE DISTRIBUTION}

Scanning Mobility Particle Sizer (SMPS)

A Scanning Mobility Particle Sizer (SMPS equipped with a Vienna-type DMA+CPC, Grimm Aerosol Technik GmbH \& CO.) was used to measure aerosol size distribution and total number concentration in the size range of 10.1-1093 nm. Fig. 7. shows the setup and the basic operation of the instrument. It consists of two main parts. The Differential Mobility Analyzer (DMA) carries out the size selection of the measured particles, that are afterwards counted in the Condensation Particle Counter (CPC). Sample air flow is $0.3 \mathrm{lmin}^{-1}$ while sheath air flow in the instrument is $3 \mathrm{lmin}^{-1}$. The instrument has 3 operational modes. In counter mode, total number concentration is measured with up to $1 \mathrm{~s}$ time resolution. In single channel mode number concentration of particles with a specific mobility diameter can be measured with up to $1 \mathrm{~s}$ time resolution within the measurement range of the instrument. In stepping mode, aerosol size distribution is measured with 7 min time resolution. Maximal detectable concentration is $10^{7}$ particles $/ \mathrm{cm}^{3}$.

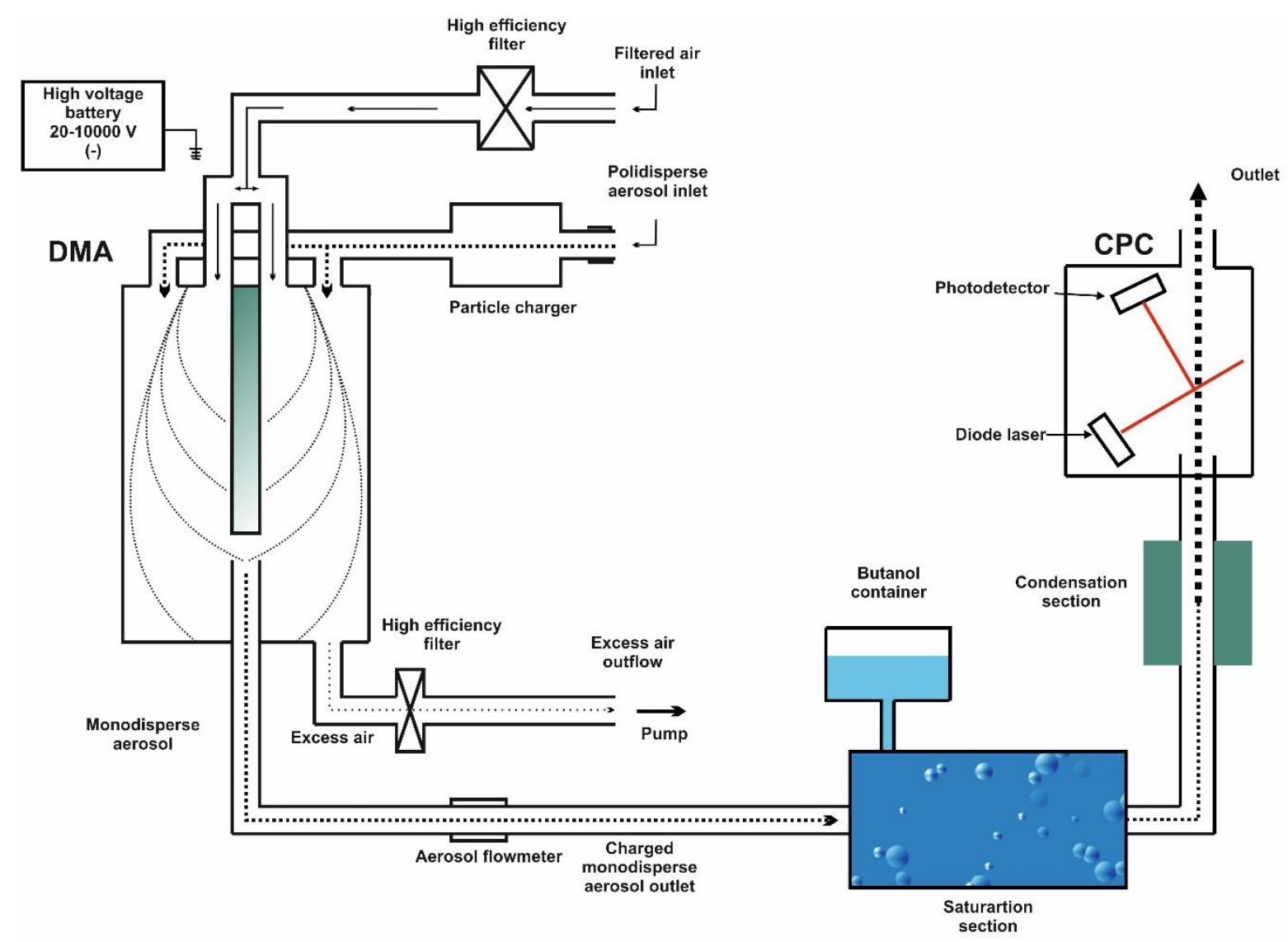

Fig. 7. Schematic view of the operating principle of the Scanning Mobility Particle Sizer including its two main parts: Differential Mobility Analyzer and Condensation Particle Counter 
In the DMA, a radioactive radiation source creates equilibrium charge distribution on the surface of particles. Particles with different electric mobility are classified in the cylinder condenser as follows. Charged particles move towards the middle of the cylinder due to the voltage set in the condenser. As particle trajectory is determined by voltage and electric mobility that is the function of size, particles of a distinct size can be classified by changing the voltage of the condenser. As classified particles are too small for optical detection, their size is increased by condensing butanol on their surface in the CPC. Particles are led through a heated porous tube, where they get mixed with steam-phase butanol. Following that they pass through a cooling unit, where butanol condenses on the surface of particles. The particle size after condensation is around $10 \mu \mathrm{m}$. Particles are counted by detecting scattered light by particles passing a laser beam in the CPC. The diffusion losses and the overcharging are corrected posteriorly on the measured data using manufacturer defined software version. The instrument was operated at standard parameters recommended by the factory manual.

\section{Portable Aerosol Spectrometer}

The Grimm Aerosol Technik GmbH \& CO. Portable Aerosol Spectrometer is an Optical Particle Counter (OPC) measuring size distribution in the size range of $0.25-32 \mu \mathrm{m}$ (Fig. 8.). Sample air enters the measuring cell through the aerosol inlet. Sample flow rate is constant $1.2 \mathrm{~min}^{-1}$. Aerosol particles are detected by light scattering inside the cell. Particles pass through a focused beam of a laser diode $(\lambda=655 \mathrm{~nm}$, Laser power $=40 \mathrm{~mW})$ while scattered light is detected by a photodiode the following way. The measured volume is illuminated inside the focused laser beam and subsequently led into the light trap. The light scattered by the measured particles is detected by a photodiode under a scattering angle of $90^{\circ}$. The $90^{\circ}$ position of the detector enables the determination of particle size independently of the refractive index of the particle. The signal of the detector is classified into 31 size channels. Maximal detectable particle concentration is $10^{6}$ particles/l. The number of impulses account for particle number concentration, the intensity of the impulses indicates particle size. 


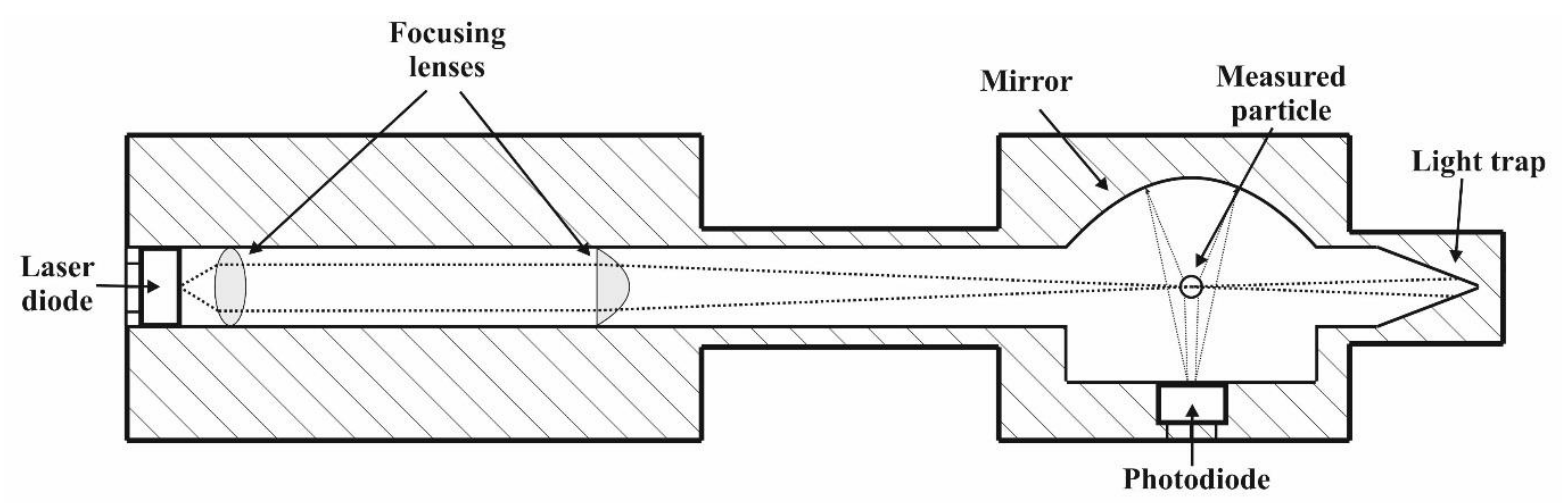

Fig. 8. Schematic view of the OPC

The OPC was used during the present field measurement campaign using standard parameters described in the instrument datasheet using 1 min time resolution. Combined with the SMPS, the size distribution of ambient aerosol was measured in three orders of magnitude (0.010-32 $\mu \mathrm{m})$. 


\subsubsection{MASS CONCENTRATION}

\section{Tapered Element Oscillating Microbalance (TEOM)}

The Thermo TEOM 1400a (Fig. 9.) measures aerosol mass concentration online. The lowest detection limit of the instrument is $0.01 \mu \mathrm{g}$. Minimal time resolution of data measurement is $2 \mathrm{~min}$. Sample flow rate can be adjusted between $1-31 \mathrm{~min}^{-1}$. Sheath air flow rate can be set between 13.67-15.67 $\mathrm{lmin}^{-1}$.

Fig. 9. shows the schematic graph of the instrument's setup and operation. The tapered element is a quartz crystal attached to a permanent magnet found in the mass measuring unit. The magnet makes the crystal vibrate at its self-frequency. Measured aerosol is sucked through a borosilicate glass filter placed on top of the tapered element. Particles get trapped by the filter, thus the self-frequency of the quartz oscillator changes. Mass concentration is calculated from the frequency-shift based on Eq. 8.

$\Delta m=K_{0}\left(\frac{1}{f_{1}^{2}}-\frac{1}{f_{0}^{2}}\right)$

where $\Delta m$ is mass change, $K_{0}$ is the instrument constant, $f_{1}$ is initial, while $f_{0}$ is final frequency.

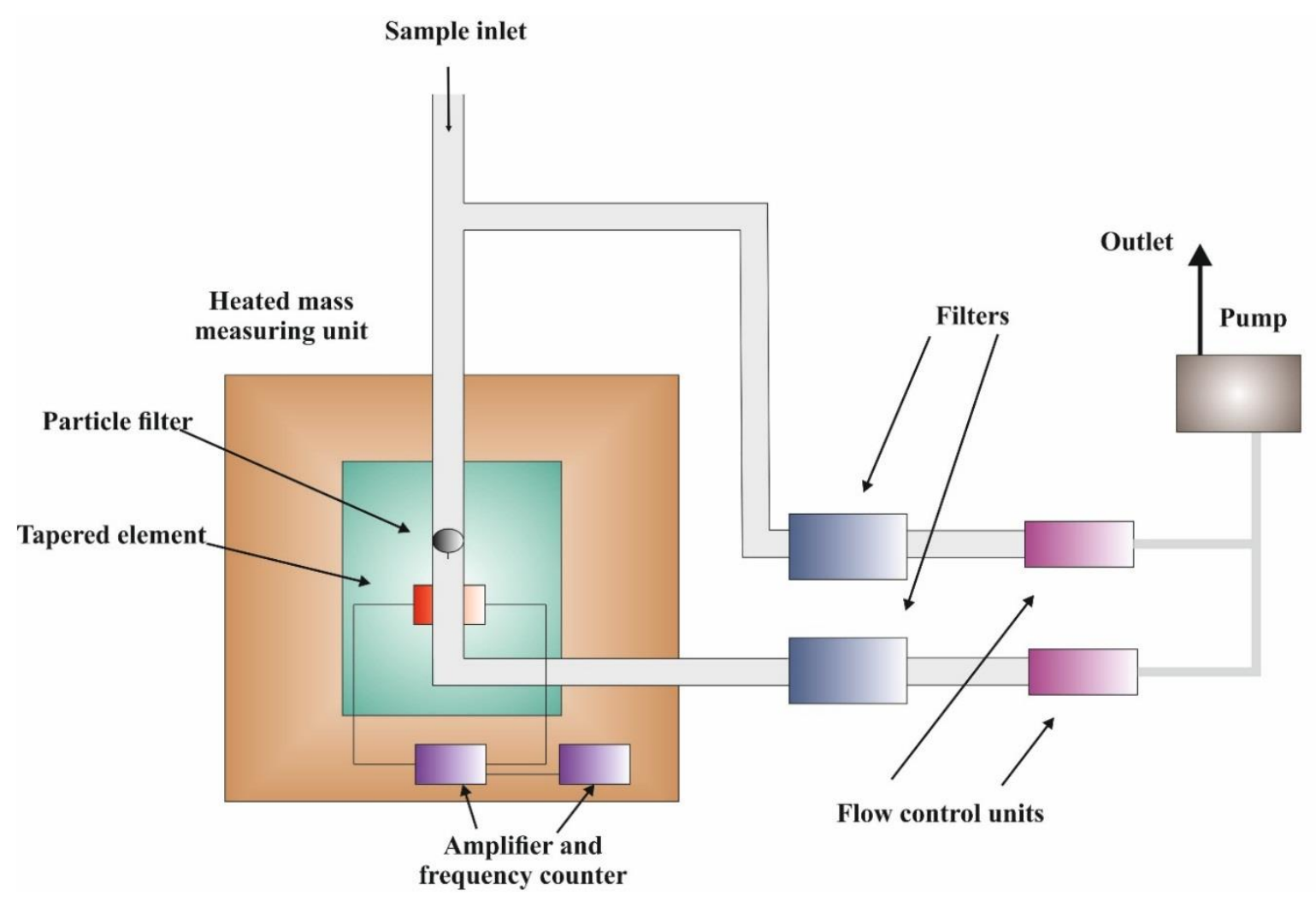

Fig. 9. Schematic view of the Tapered Element Oscillating Microbalance 
Following that, mass concentration $\left(\mu \mathrm{g} / \mathrm{m}^{3}\right)$ is calculated based on mass change, sampling flow rate and sampling time. Before mass is measured, sampled air is heated to $40^{\circ} \mathrm{C}$ to avoid measurement errors due to the condensation of water vapour.

Regarding the presented data, the instrument was operated at $31 \mathrm{~min}^{-1}$ sample flow rate and 2 min data time resolution.

\section{Met One Instruments BAM 1020 beta attenuation mass monitor}

The Met One Instruments BAM 1020 beta attenuation mass monitor automatically measures particulate mass concentration based on beta ray attenuation. A small ${ }^{14} \mathrm{C}$ (carbon 14 ) element inside of the BAM 1020 provides a constant source of beta rays. A glass fibre filter tape is passed through the path of beta rays before being detected with a scintillation detector. At the beginning of the measurement cycle the beta ray count across clean filter tape is recorded $\left(\mathrm{I}_{0}\right)$. Then, PM-laden air is sucked through the filter tape trapping the particles on the filter tape. At the end of the measurement cycle the beta ray count is re-measured across PM-loaded filter tape $\left(I_{1}\right)$. The ratio of $I_{0}$ to $I_{1}$ is used to determine the mass density of collected PM on the filter tape.

Data from the BAM 1020 instrument was kindly provided by the mobile air quality monitoring station of the Lower Tisza Valley Environmental Inspectorate (its present name: Government Office of Csongrád county), Szeged, Hungary.

\subsubsection{CO, NOx AND BTEX CONCENTRATION}

$\mathrm{CO}$, NOx, and BTEX (benzene, toluene, m,p-xylen, o-xylen and ethylbenzene) are among the gaseous atmospheric compounds most commonly used for describing urban air quality (Fine et al., 2002, Favez et al., 2010). On one hand, they have severe impact on human health. On the other hand, $\mathrm{CO}$ and $\mathrm{NO}_{\mathrm{x}}$ are commonly accepted tracers of emission from household heating and traffic, respectively (Fine et al., 2002, Puxbaum et al., 2007, Sandradewi et al., 2008a, Favez et al., 2010). Their concentration was determined by a Syntech Spectras GC955 Gas Chromatograph (Synspec b.v.) as supplementary parameters supporting the discussion of our field measurement. Gas concentration data was kindly provided by the mobile air quality monitoring station of the Lower Tisza Valley Environmental Inspectorate (its present name is Government Office of Csongrád county), Szeged, Hungary. 


\subsection{OFFLINE METHODS}

Most offline investigations were carried out in cooperation with other institutions using several different methodologies. The investigation of particle morphology and microstructure using TEM was carried out by the Department of Applied and Environmental Chemistry at the University of Szeged. LG and PAH concentrations in filter samples were determined by the Department of Earth and Environmental Sciences at the University of Pannonia. Particulate matter ecotoxicity was assessed by the Institute of Environmental Sciences at the Pannon University. In this section, only the applied protocols and some project related details are described briefly.

\subsubsection{MORPHOLOGY AND MICROSTRUCTURE}

Morphology and the microstructure of aerosol particulates were determined by Transmission Electron Microscopy (TEM, FEI Tecnai G2 20 X-Twin) and Raman Spectroscopy (Thermo Scientific DXR Raman Microscope). The TEM was operated at $200 \mathrm{kV}$ accelerating voltage. Morphology investigations were carried out on carbon coated 200 mesh copper grids (CF200-Cu, Electron Microscopy Sciences, USA), while for the characterization of the microstructure of the primary particles lacey carbon grids (LC200-Cu, Electron Microscopy Sciences, USA) were used. Before imaging, grids were placed in a polystyrene Petri dish and equilibrated in a desiccation chamber at $\sim 25{ }^{\circ} \mathrm{C}$ and $\sim 20 \% \mathrm{RH}$. Electron Diffraction (ED) and high-resolution electron microscopy (HRTEM) mode were used to measure the degree of crystallinity of the interrogated particles, with a point to point resolution of $0.26 \mathrm{~nm}$. To avoid the fractal displacement during the exposition on the grid in the HRTEM mode, samples were preheated before imaging.

\subsubsection{TC, EC AND OC CONCENTRATIONS Semi Continuous OCEC Analyzer (Sunset Laboratory Inc.)}

$\mathrm{EC}, \mathrm{OC}$ and $\mathrm{TC}$ (hereafter quoted as $\mathrm{TC}_{\text {Sunset }}$ ) concentrations were determined by a thermo-optical Semi Continuous OCEC Analyzer (Sunset Laboratory Inc.) using protocol EUSAAR_2 (Cavalli et al., 2010). The theory of operation and the measurement protocol is described in detail by Bauer et al., 2009. Karanasiou et al., 2015 reviewed thermal-optical analysis for the measurement of EC and OC in ambient air. Only a brief explanation is given in this section.

During sample collection, ambient air is sucked through a quartz fibre filter (Whatman QM-A Quartz Microfiber Filters (diameter of $150 \mathrm{~mm}$ ) (GE Healthcare Life Sciences)) for a 
pre-determined duration. After the collection, in the first phase the sample is heated to $650^{\circ} \mathrm{C}$ in 4 steps in oxygen-free He atmosphere. That way organic carbon can be volatilized. During this phase, up to $30 \%$ of OC can be pyrolytically converted to elemental carbon. This conversion is continuously monitored, and measured data is corrected by measuring the transmission of a $670 \mathrm{~nm}$ laser through the filter matrix. Vaporized organic compounds are converted to $\mathrm{CO}_{2}$ in a manganese dioxide $\left(\mathrm{MnO}_{2}\right)$ oven. Than $\mathrm{CO}_{2}$ is detected by a NonDispersive Infrared Detector (NDIR). $\mathrm{CO}_{2}$ concentration is proportional to $\mathrm{OC}$ concentration on the filter. During the second phase, the sample is cooled to $500^{\circ} \mathrm{C}$, following which it is heated up to $850^{\circ} \mathrm{C}$ in three subsequent steps in $2 \% \mathrm{O}_{2} / \mathrm{He}$ gas ambience. In this phase both elemental and pyrolyzed carbon are converted to $\mathrm{CO}_{2}$ due to the presence of $\mathrm{O}_{2} \cdot \mathrm{CO}_{2}$ is detected as previously described. In the last step, a known concentration of $\mathrm{CH}_{4}$ is injected into the sample oven, serving as calibration for each analysed sample. EC, OC and TC content of the sample are calculated based on the measured NDIR and laser transmission data.

Total carbon (TC) concentration was also measured by a Zellweger Analytics Astro 2100 TOC Analyzer by the EGA method (hereafter quoted as $\mathrm{TC}_{\text {Zellweger}}$ ) from the filter extracts. The carbon content of the sample was catalytically converted to $\mathrm{CO}_{2}$ at $680^{\circ} \mathrm{C}$, that was afterwards measured by an NDIR detector. Three replicates were measured from each sample.

\subsubsection{LG CONCENTRATION}

The levoglucosan (LG) concentration was determined as follows. First the filters were spiked with the internal standard methyl-beta-Larabinopyranoside. The filters were dried and extracted in two steps. During the first extraction step dichloromethane was used, whereas in the second step the extractant was a 80:20 dichloromethane:methanol mixture. The extracts were filtered through a $0.45 \mu \mathrm{m}$ syringe filter (Millipore MillexHV). Following that the extracts were dried until dryness under a gentle stream of nitrogen. For derivatization a 50\% BSTFA (N,O-bis(trimethylsilyl)trifluoroacetamide) containing 1\% of TMCS (trimethylchlorosilane) and $50 \%$ pyridine mixture was added to the samples and placed in an oven at $70^{\circ} \mathrm{C}$ for $3 \mathrm{~h}$. The samples were measured with an Agilent $6890 \mathrm{~N}$ gas chromatograph coupled to an Agilent $5973 \mathrm{~N}$ mass spectrometer. The separation was performed on an Agilent DB-5ms Ultra Inert capillary column $(30 \mathrm{~m} \times 0.25 \mathrm{~mm} \times 0.25 \mu \mathrm{m})$. 


\subsubsection{PAH CONCENTRATION}

EPA priority pollutants of $12 \mathrm{PAH}$ compounds (phenantrene, anthracene, fluorantene, pyrene, Benzo[a]anthracene, chrysene, Benzo[b]fluoranthene, Benzo[k]fluoranthene, benzo[a]pyrene, Dibenz[a,h]anthracene, Benzo[g,h,i]perylene, Indenopyrene) were determined from filter extracts using High Performance Liquid Chromatography (HPLC). For the separation of PAHs, HPLC grade acetonitrile and water (from a MilliQ system, Water, Milford) were used. The LC system consisted of a Waters 600E pump, Rheodyne 7125 injector with 20 $\mu \mathrm{L}$ loop, LiChrospher PAH column $(250 \times 4 \mathrm{~mm}, \mathrm{dp}=5 \mathrm{~mm})$ and Waters 470 fluorescence detector. Elution was provided by the following method: linear gradient from $40 \%$ acetonitrile in water to $100 \%$ acetonitrile in $20 \mathrm{~min}$ then $100 \%$ acetonitrile for $15 \mathrm{~min}$ at $1 \mathrm{~mL} \mathrm{~min}^{-1}$. To achieve higher selectivity and sensitivity, time programmed excitation and emission wavelengths were used. Data acquisition and processing were provided by the Maxima 820 (Waters) chromatography software (Kiss et al., 2009)

\subsubsection{ECOTOXICITY (EC50)}

\section{Vibrio Fischeri Bioluminessence Inhibition Bioassay}

The Vibrio Fischeri bioluminescence bioassay was applied for determining the ecotoxic potential of filter collected PM samples following the protocol as described in the ISO 21338:2010 standard. Half maximal effective concentration (EC50) values were calculated using Ascent Software provided by Aboatox Co., Finland. Ecotoxicity (EC50) of a filter sample is determined as the absolute mass of particles that causes 50\% reduction in the bioluminescence output of the test organisms relative to the control under the given experimental conditions. Therefore, EC50 is expressed in units of $\mu \mathrm{g}$ as calculated from measured mass of aerosol on the total filter by scaling to the area of the sample spot. The lower is the value of EC50, the higher is the ecotoxicity of the sample. 


\section{RESULTS AND DISCUSSION}

\subsection{GENERATION AND CHARACTERIZATION OF ARTIFICIALLY GENERATED CARBONACEOUS PARTICULATE MATTER}

Atmospheric soot is characterized based on the measurement of its specific properties including size distribution, morphology, thermal stability and optical response. These complex properties can have vast variety depending on circumstances of formation like burning conditions, fuel type as well as initial and actual atmospheric processes. Therefore, the lack of a well-controlled modelling procedure of soot formation for the precise and accurate investigation of the nascent soot properties is a major obstacle in reducing the uncertainties associated with the identification of this component among real measurement conditions (Baumgardner et al., 2012; Gysel et al., 2011).

An ideal soot generation method should not only be able to provide model particles with a specific parameter set but also have a possibility to control the conditions of formation, thus all relevant properties independently from each other. Commercially available generation techniques based on specially designed gas burners and graphite electrode spark dischargers only partially fulfil the above-mentioned requirements (Schnaiter et al., 2003, 2006; Kirchstetter and Novakov, 2007). Based on this, introducing novel methods for generating CPM that can model atmospheric soot among various well-defined chemo-physical parameters is an important scientific goal of our time.

For the controlled generation of CPM, I proposed to use the laser ablation method. This method ensures the independent control of particle properties through the generation parameters. In this chapter, I present the description of the measurement setup, the basic process of the particle formation phenomenon. I also characterize the microphysical properties of the generated CPM in the function of the generation parameters. 


\subsubsection{MEASUREMENT SETUP OF THE CPM GENERATOR}

The measurement setup of the CPM generator based on laser ablation is displayed on Fig. 10. For the excitation of the target material Krypton Fluoride (KrF) excimer laser (LLG TWINAMP) beam was used. The operational wavelength and the pulse duration and repetition rate of the excimer laser were $248 \mathrm{~nm}$ and $18 \mathrm{~ns}$ and $1 \mathrm{~Hz}$, respectively. The laser energy on the surface of the ablated sample was determined by an energy meter (Laser Probe Inc., Rm-3700) through a quartz plate energy coupler. The laser fluence (laser energy per irradiated sample area) was systematically varied between $0.5-2.9 \mathrm{~J} \mathrm{~cm}^{-2}$. High purity graphite disc (Goodfellow, purity $>99.95 \%$ ) with a diameter and thickness of 20 and $5 \mathrm{~mm}$, respectively was used as target material for CPM generation. The graphite disc was placed and irradiated in an ablation chamber (Fig. 12), which was a modified version of a PLD (pulsed laser deposition) chamber described in detail earlier (Ajtai et al., 2010b; Hopp et al., 2012). The cylindrically shaped ablation chamber is made of stainless steel with an inner diameter and length of 3 and $10 \mathrm{~cm}$. The laser beam was focused into the chamber through a fused silica window at an angle of $45^{\circ}$ with respect to the surface of the irradiated sample.

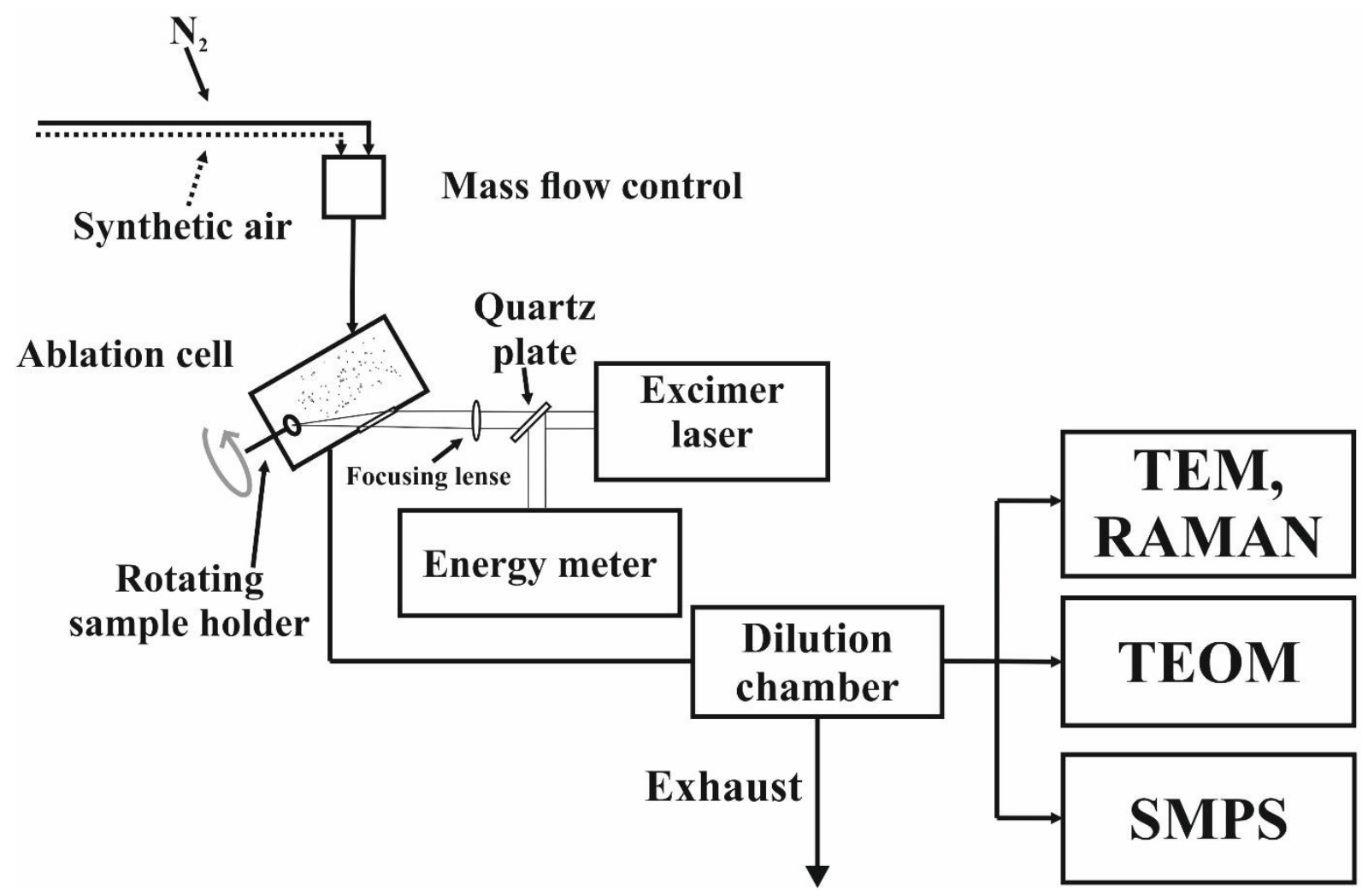

Fig.10. Measurement setup of the CPM generator based on laser ablation

To improve the stability of particle yield, the target was placed onto a rotating sample holder and the angular speed of rotation was matched with the repetition rate of the laser and 
the dimension of the irradiated spot to ensure uniform sample etching, i.e., quasi-homogeneous ablated target surface structure and consequently uniform material ejection over a prolonged period (Ajtai et al., 2010b; Hopp et al., 2012). This way stable particle production could be realized for several hours. High purity nitrogen and synthetic air (5.0 certified purity), as well as their mixtures were used as purging gases. The flow rate of purging gas was varied from 200 $\mathrm{cm}^{3} \mathrm{~min}^{-1}$ to $1000 \mathrm{~cm}^{3} \mathrm{~min}^{-1}$ controlled by mass flow controllers (MFCs, Tylan 2900FC) during the measurements. The generated CPM were carried by the purging gas into a dilution chamber from which the measurement instruments could carry out sampling. Measurements were performed at room temperature and atmospheric pressure ensured by an exhaust pipe attached to the dilution chamber.

The reproducibility of the generated CPM was determined from 60 size distribution spectra gathered from 2 hours continuous measurement period that was repeated 3 times on 3 different days at the laser fluence of $2 \mathrm{Jcm}^{-2}$. The main critical sources of errors in the presented methodology are the optical alignment and the long-term instability of the applied laser source. These together with the uncertainty of gas flow rates of the purging gas mixtures $( \pm 5 \%)$ limit the reproducibility of the setup. However, overall uncertainty of determining CMD, GSD and the TNC was found to be below $10 \%$. That is considered typical for real-time soot generators and is in the range of detector instability (Spanner et al., 1994; Horvath and Gangl, 2003). 


\subsubsection{PARTicle fORMATION PROCESS}

Particle formation process during combustion, modelled by our ablation-based set-up, can be divided into three subsequent phases: nucleation, coagulation and aggregation (Gelencsér, 2004).

Nucleation phase: High energy excitation of the fuel (target material) induces phase changes. That results in an ablation plume that contains different vapours and fragments originating from the target material. Following that, newly formed vapours and fragments drift away from the site of excitation and cool down. That way new bonds form between these components. That results in (primary) nanoparticles serving as nuclei in the subsequent (coagulation) phase of particle generation.

Coagulation phase: During the coagulation phase, primary particles (formed during the nucleation phase) collide, and due to the favourable energy conditions, new spherical particles are formed (Seinfeld, 1986). The volume of newly formed particles is roughly equal to the sum of the volume of the individual particles. However, the surface of new particles is much smaller than the sum of the surface of the colliding ones particularly in the smaller diameter size domain. The coagulation phase lasts until it is energetically more efficient for spherical particles to grow than further growing by forming of weak bond between two spherical particles through collision. Thereafter, the coagulation phase is followed by the aggregation phase.

Aggregation phase: After the period of coalescent growth, colliding particles become weakly bonded to one another creating fractal aggregates with a complex morphology. Soot agglomerates are chain-like structures of nearly equal sized spherical particles. Soot fractal aggregates are most commonly characterized by the following relationship (Eq. 9) (Jullien and Botet, 1987):

$n=k_{f}{\frac{\left(2 R_{g}\right)^{D_{f}}}{D_{p}}}^{D}$

where $\mathrm{n}$ is the number of primary particles in an aggregate, $\mathrm{D}_{\mathrm{p}}$ is the diameter of primary particles, $\mathrm{R}_{\mathrm{g}}$ is the radius of gyration of an aggregate, $\mathrm{D}_{\mathrm{f}}$ is the fractal dimension, and $\mathrm{k}_{\mathrm{f}}$ is the fractal prefactor.

The mathematical formulation of both the coagulation and aggregation of soot particles is described in detail elsewhere (Kazakov and Frenklach, 1998). Here only the following simplified approximation is used: Nucleation is a gas to aerosol transition process, while 
coagulation and aggregation are competing physical phenomena. Their relative dominance is primarily determined by the ratio of coalescence and collision time. (Hawa and Zachariah, 2006):

$\tau_{\text {coalescence }}<\tau_{\text {collision: }}:$ coagulation $\rightarrow$ spherical particles

$\tau_{\text {coalescence }}>\tau_{\text {collision: }}$ aggregation $\rightarrow$ fractal aggregates

When coalescence time is much lower than collision time, the formation of new spherical particles becomes dominant through coagulation. If collision time is shorter than coalescence time, soot fractal aggregates are formed by aggregation. 


\subsubsection{CHARACTERIZATION OF THE GENERATED CPM IN THE FUNCTION OF GENERATION PARAMETERS}

In this section, the determined microphysical, morphological and microstructural characteristics of the generated CPM are presented in the function of the various generation parameters applied during the measurements. First, the mass concentration of particle yield is discussed in the function of laser fluence. Following that the size distribution of generated CPM is examined in three subsequent subchapters in the function of laser fluence, carrier gas flow rate and carrier gas composition, respectively. Finally, the morphology and microstructure of generated particles is discussed and compared to those of real ambient soot particles.

All presented measurements were carried out in nitrogen gas at $500 \mathrm{~cm}^{3} \mathrm{~min}^{-1}$ volumetric flow rate using $2.5 \mathrm{~J} \mathrm{~cm}^{-2}$ fluence unless where otherwise stated.

\section{The effect of altering laser fluence on the generated CPM}

Mass concentration of the generated CPM was determined in the function of laser fluence (Fig. 11.). Two dominant laser fluence domains were determined separated by about $0.9 \mathrm{~J} \mathrm{~cm}^{-2}$ fluence value. Mass concentration of the generated aerosol particles was found to be close to zero and independent of the applied fluence below $\sim 0.9 \mathrm{~J} \mathrm{~cm}^{-2}$. Above this limit, mass concentration increased approximately linearly with the fluence. The differences in yields can be explained by the different ablation mechanism taking place at different fluences (Márton et al., 2003; Steinbeck et al., 1985; Venkatesan et al., 1984). At low fluences, laser excitation causes physical interactions i.e. fragmentations that primarily depends on the irradiated area thus largely independent from the variation in fluence (Márton et al., 2003; Steinbeck et al., 1985; Venkatesan et al., 1984). Above the ablation threshold value, aerosol yield depends mostly on the thermochemical properties of the target material. It is proportional to the whole ablation volume determined by the penetration depth of the laser pulses (Ajtai et al., 2010b; Hopp et al., 2012). Thus, increasing fluence results in higher aerosol yield. 


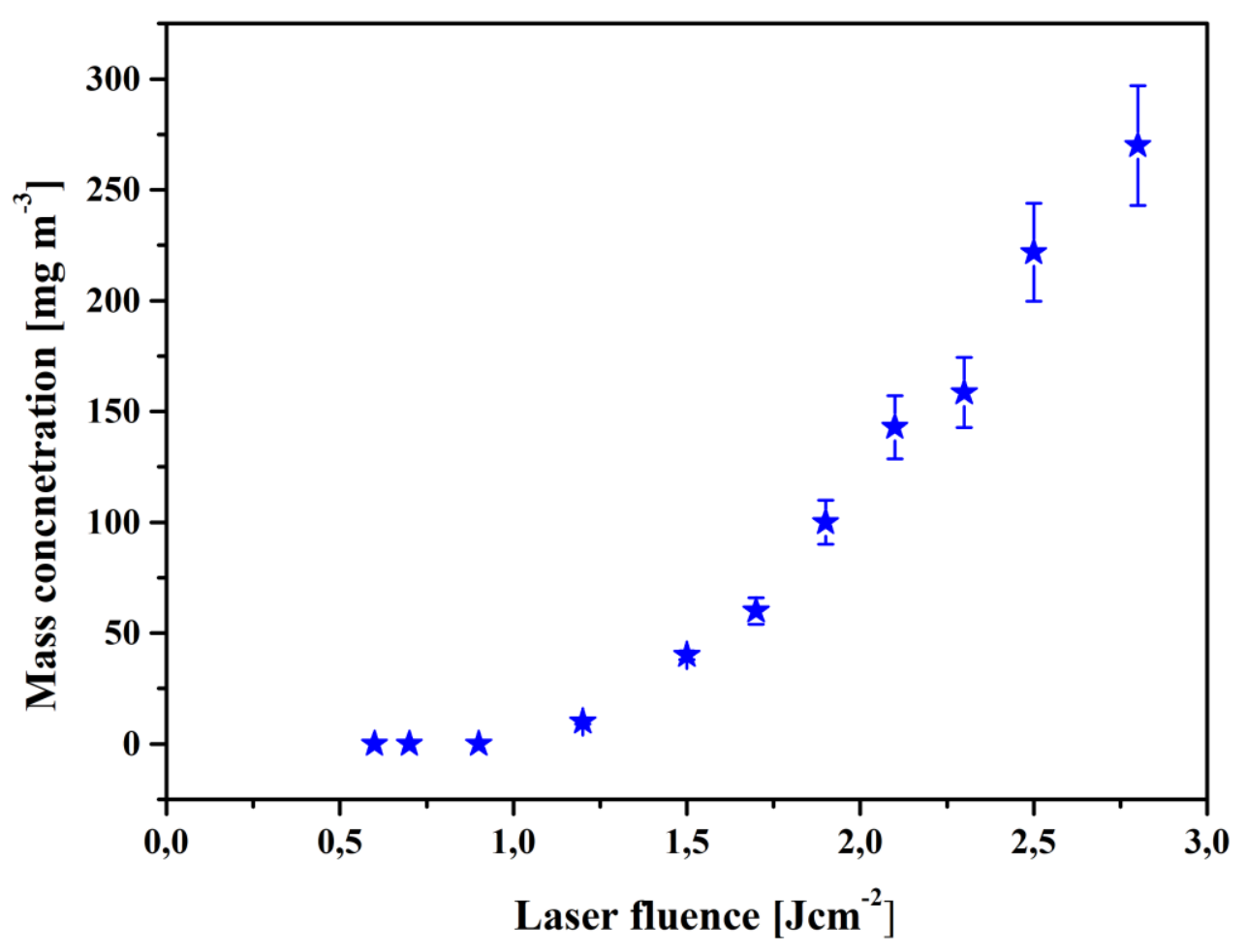

Fig. 11. Mass concentration in the function of laser fluence

The size distribution of the generated particulates was also measured in the function of laser fluence. Three different characteristic fluence domains have been identified. Fig. 12. shows size distributions measured at three distinctive (low, intermediate and high) laser fluence values. 


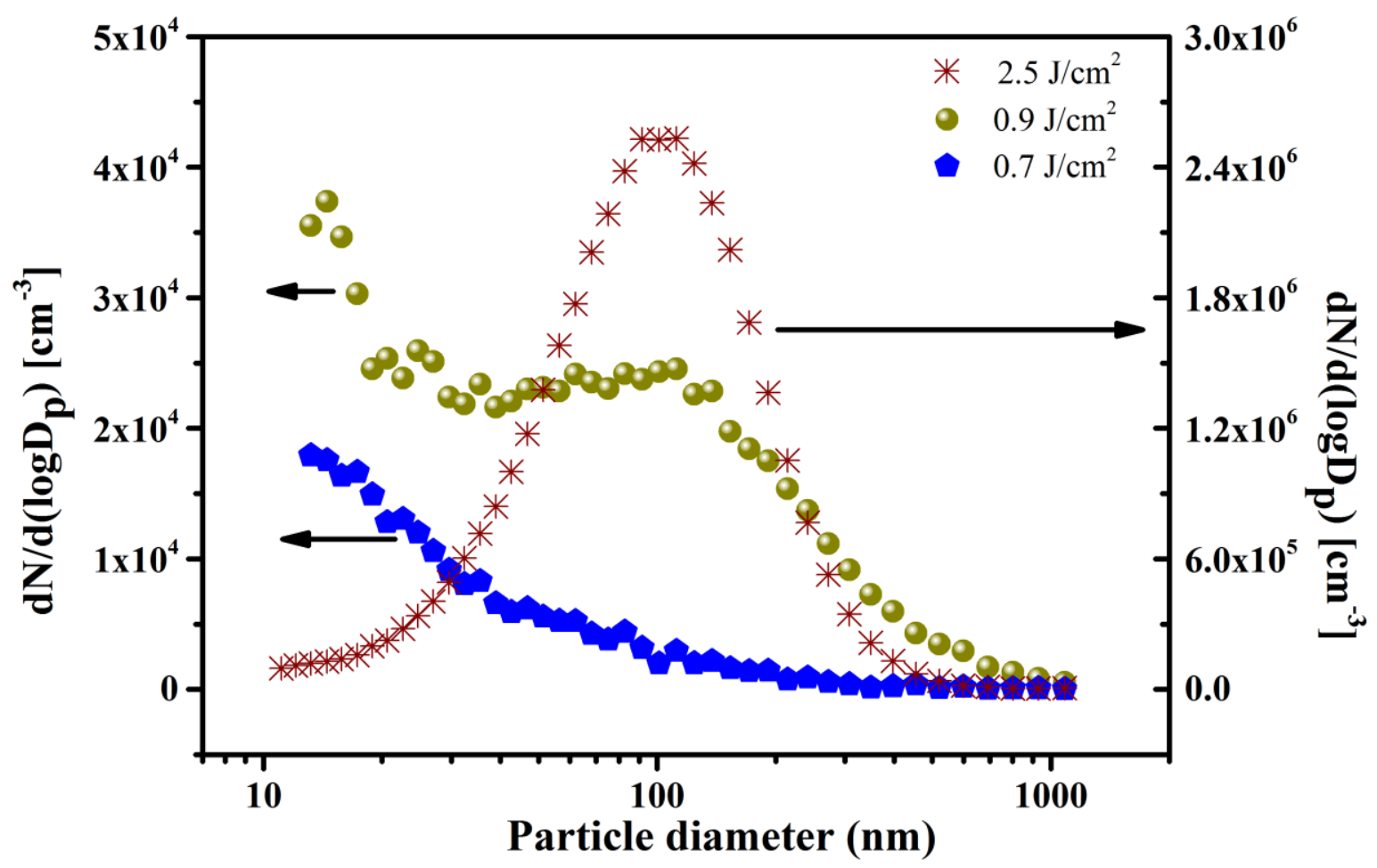

Fig. 12. Size distribution curves at three characteristic laser fluence values

At low laser fluence $\left(<0.7 \mathrm{~J} \mathrm{~cm}^{-2}\right)$ dominantly primary nano-particles were generated in relatively high number concentration (Fig 14 and17a). According to Fig 14 and Fig 17a, the number of fractal aggregates are low compared to primary particles. Such behaviour can be explained by the insufficient number of primary particles for inefficient fractal aggregation. Therefore, evolved primary particles are too small to overcome the size limit for the aggregation process to take place. Results can also indicate that in the low laser fluence domain coalescence time is much shorter than the collision time (Section 5.1.3.).

$0.9 \mathrm{~J} \mathrm{~cm}^{-2}$ is the laser fluence regime, where the particle yield is no more totally independent but not so far linearly proportional to laser fluence. In this intermediate laser fluence regime, primary particles are present in still high number concentration, however the number of fractal aggregates with more complex morphology also increases significantly compared to the previous fluence domain (Fig 14. and Fig 17b and c). The number of collisions is presumably already favourable for aggregation in this regime. Therefore, coalescence and collision times are assumed to be roughly equal in this domain.

At high fluence values ( $>2.5 \mathrm{~J} \mathrm{~cm}^{-2}$ ), where the particle yield is proportional to the laser fluence, fractal aggregates become dominant in the generated CPM, the number concentration of primary particles does not increase further. The most probable reason for such behaviour is 
that at such high fluences, partly due to the increased possibility of collision, most primary particles are consumed by cluster formation. In this fluence domain, coalescence time must be longer than the collision time.

Above $1 \mathrm{~J} \mathrm{~cm}^{-2}$, the size distribution of the generated CPM can be typified with a monodisperse lognormal distribution. The lognormal distribution of carbonaceous aerosols can be described by three characteristic parameters (CMD, GSD and TNC) determined by the lognormal fitting algorithm (Heintzenberg, 1994). Fit parameters can be found in Table. 1. Total number concentration (TNC) grows proportionally to laser fluence as expected from Fig. 13. However, the shape of the SD parameters displayed non-monotonic tendencies in the function of laser fluence. CMD and GSD both decreased in the function of laser fluence up to the fluence value of $2.1 \mathrm{Jcm}^{-2}$. Over that value neither CMD nor GSD displayed significant variation in the function of laser fluence, although a slight increase was observed at $2.8 \mathrm{Jcm}^{-2}$. As opposed to that, TNC monotonously increased in the function of laser fluence over the whole laser fluence range.

Table 1. Fit parameters of the measured size distribution curves at various laser fluence values $\left(>1 \mathrm{~J} \mathrm{~cm}^{-2}\right)$

\begin{tabular}{ccccccccc}
\hline Laser fluence $\left[\mathrm{J} \mathrm{cm}^{-2}\right]$ & 1.25 & 1.5 & 1.7 & 1.9 & 2.1 & 2.3 & 2.5 & 2.8 \\
\hline CMD $[\mathrm{nm}]$ & 175.4 & 152.9 & 147.2 & 147.4 & 137.9 & 157.6 & 158 & 162.8 \\
\hline GSD $[\mathrm{nm}]$ & 233.8 & 196.9 & 158.3 & 157.4 & 137.1 & 163.8 & 164.7 & 169.3 \\
\hline TNC $\left[10^{6} \mathrm{~cm}^{-3}\right]$ & 0.8 & 1 & 1.8 & 2.3 & 2.8 & 3.3 & 3.6 & 4.3 \\
\hline
\end{tabular}


The effect of altering volume flow in the ablation cell on the generated CPM

Fig. 13 shows the changes in measured size distribution in the function of volumetric flow rate of purging gas $\left(\mathrm{N}_{2}\right)$ in the ablation chamber. By reducing the gas flow rate, the SD curves shifted towards larger particles while the peak of the curve increased. According to this, both TNC and CMD can be increased in the function of purging gas flow rate. A possible explanation of that is the following: at a lower volumetric flow rate, the residual time of the purging gas in the ablation chamber is longer, while the emission rate of the ablated particles remains constant. Therefore, reduced flow rate increases the probability of particle collision, because of which the size (CMD) of the aggregates could increase. Meanwhile, TNC increases because the particles are generated at same rate, yet they are engulfed by a smaller gas volume.

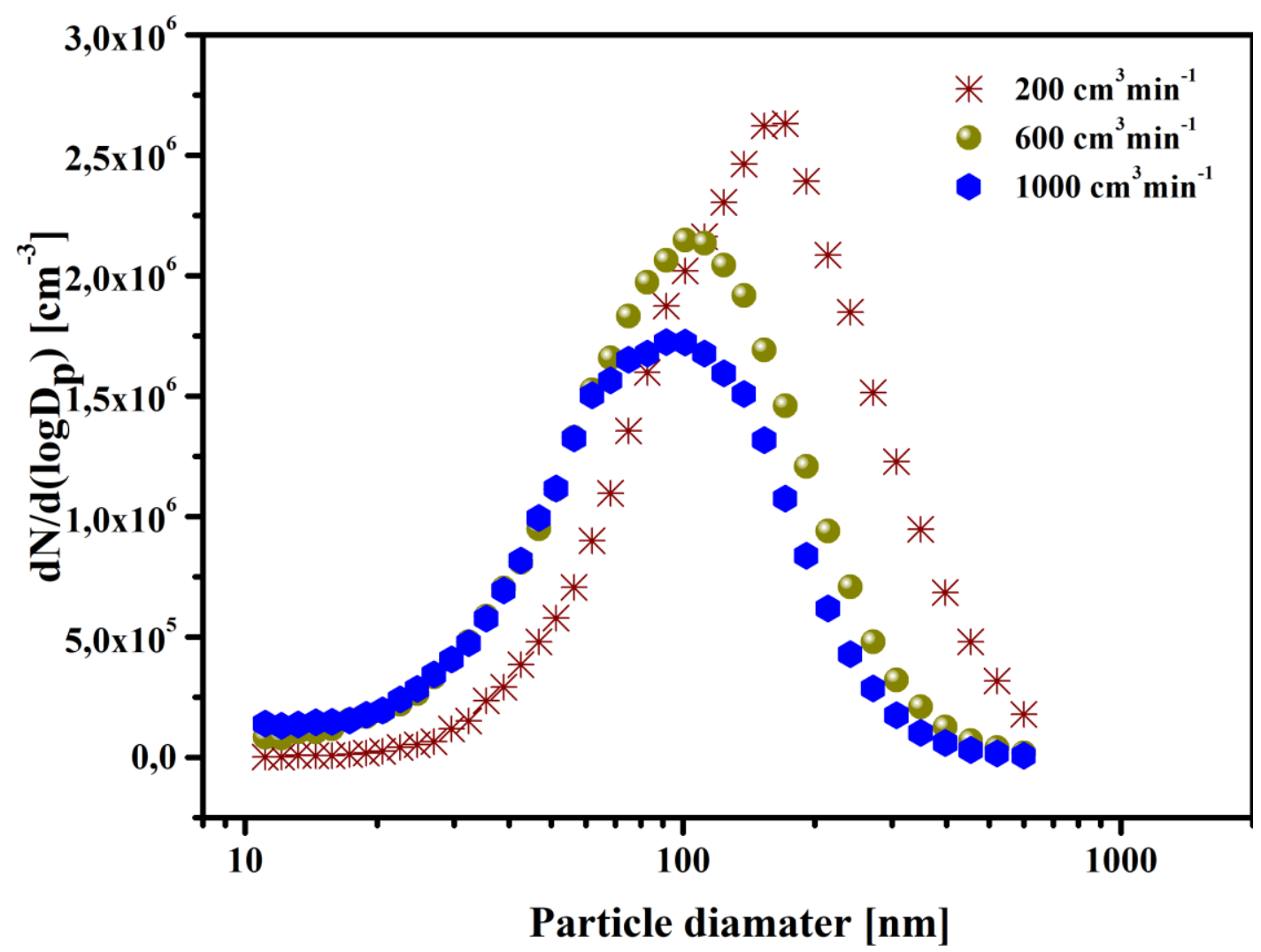

Fig. 13. Measured size distribution curves in the function of volume flow rate in the ablation chamber 
Fig. 14 shows size distribution curves of CPM generated in various purging gas mixtures. Based on the applied gas ambient remarkably varying SDs were observed. SD measured in pure $\mathrm{N}_{2}$ carrier resulted in a monomodal SD dominated presumably by fractal aggregates. When particles are generated in synthetic air SD is radically shifted towards to the smaller size domain. The particle assembly generated in synthetic air mostly consists of primary particles $(\mathrm{d}<40 \mathrm{~nm})$. In case of mixtures of pure $\mathrm{N}_{2}$ and synthetic air, SD is still mostly dominated by primary particles, however, the presence of fractal aggregates becomes more decisive as well.

Based on these, applying different mixtures of $\mathrm{N}_{2}$ and synthetic air enables the controlled generation of primary particles and fractal aggregates as well as their mixtures. The lack or small portion of fractal aggregates in purging gases containing synthetic air is due to concomitant oxidation. Accordingly, the presence of synthetic air in the gas ambience can lead to changes in the chemical composition of the generated particles through oxidation as well.

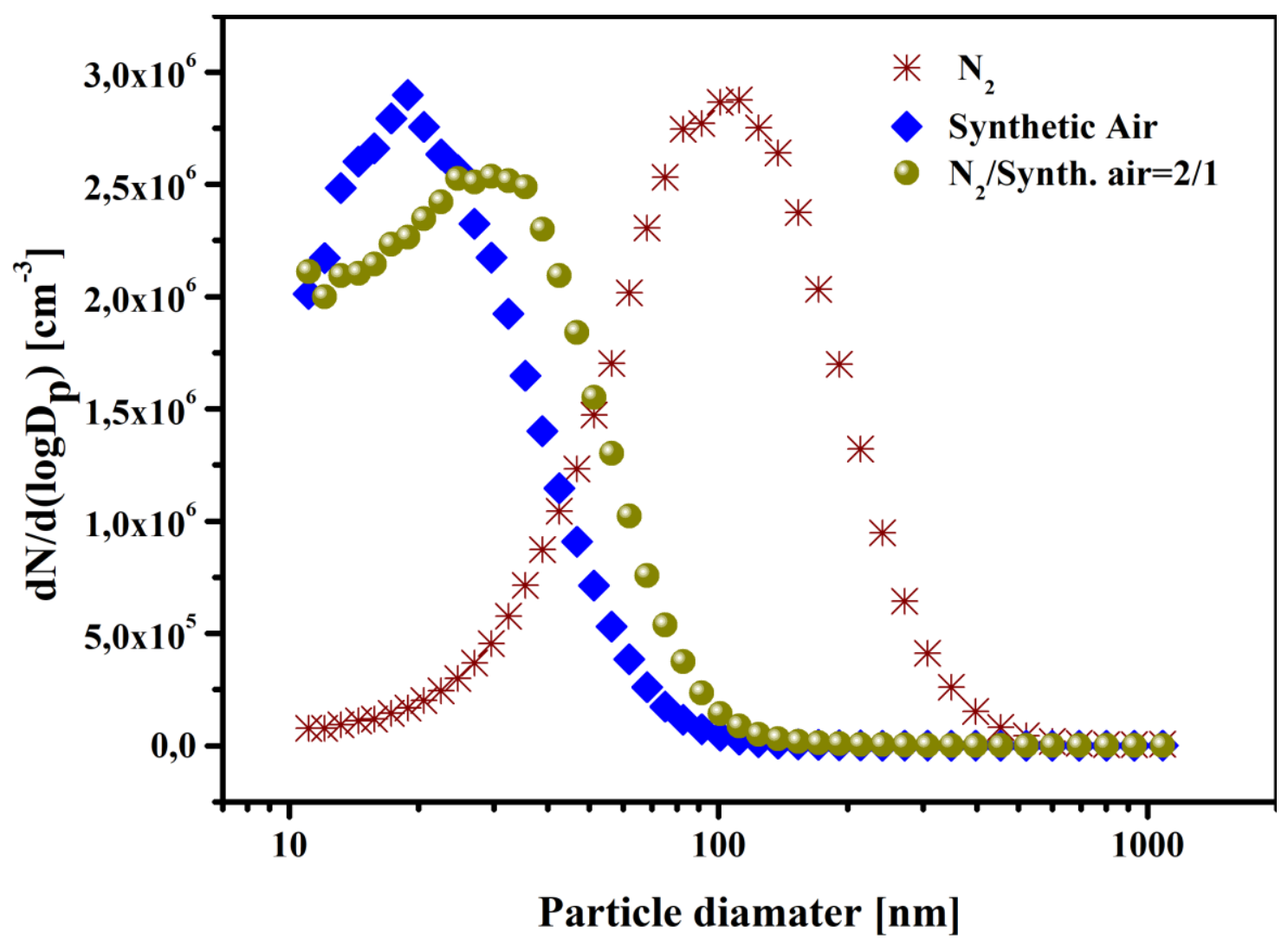

Fig. 14. Size distribution curves of CPM generated in purging gases of various composition 


\section{Morphology and microstructure of the generated particles}

Apart from the online investigations, the morphology and the microstructure of the generated particles were studied as well using offline chemical methodologies.

The morphology of the generated particles was investigated by TEM. Fig. 15a-c displays TEM images of three representative soot particle structures. Figure 17 a. shows primary particles with the average diameter of $7 \pm 0.8 \mathrm{~nm}$ collected at $0.7 \mathrm{~J} \mathrm{~cm}^{-2}$ fluence in nitrogen purging gas. Figure $15 \mathrm{~b}$ and $\mathrm{c}$ demonstrate more complex soot structures corresponding to 0.9 and $2.5 \mathrm{~J} \mathrm{~cm}^{-2}$ laser fluences, respectively. The average diameter of primary particles building up fractal aggregates was determined from the images of about 200 primary particles. It was found to be in the 8.5 to $13.7 \mathrm{~nm}$ range with the average diameter of $9.9 \pm 2.3$ (Fig. 15b and c). Fractal dimension of the generated aggregates was determined using an image analysis software (Digital Micrograph 3, Gatan Inc.; Park et al., 2004) based on Eq. 10. The fractal dimensions of well separated aggregates on the grid associated with 0.9 and 2.5 $\mathrm{J} \mathrm{cm}^{-2}$ fluences ranged from 1.65 to 2.1 with the mean value of $1.88 \pm 1.4$.

Apart from morphology, the microstructure of the generated particles was investigated by HR-TEM. Fig. 15d-f demonstrates HR-TEM images of the structural properties of the primary particles obtained at $2 \mathrm{~J} \mathrm{~cm}^{-2}$ fluence. Besides some amorphous and disordered arrangements, laser-generated soot particles had the typically onion-like (graphitic) structure where graphene layers are oriented parallel to the external outer surface (Fig. 15d), locally and concentrically structured graphene layers but with random orientation respect to each other (Fig. 15e), and graphene layers structured parallel to each other but without concentric orientation (Fig. 15f). The typical distance between the layers is about $0.34 \mathrm{~nm}$ (Fig. 15d). 

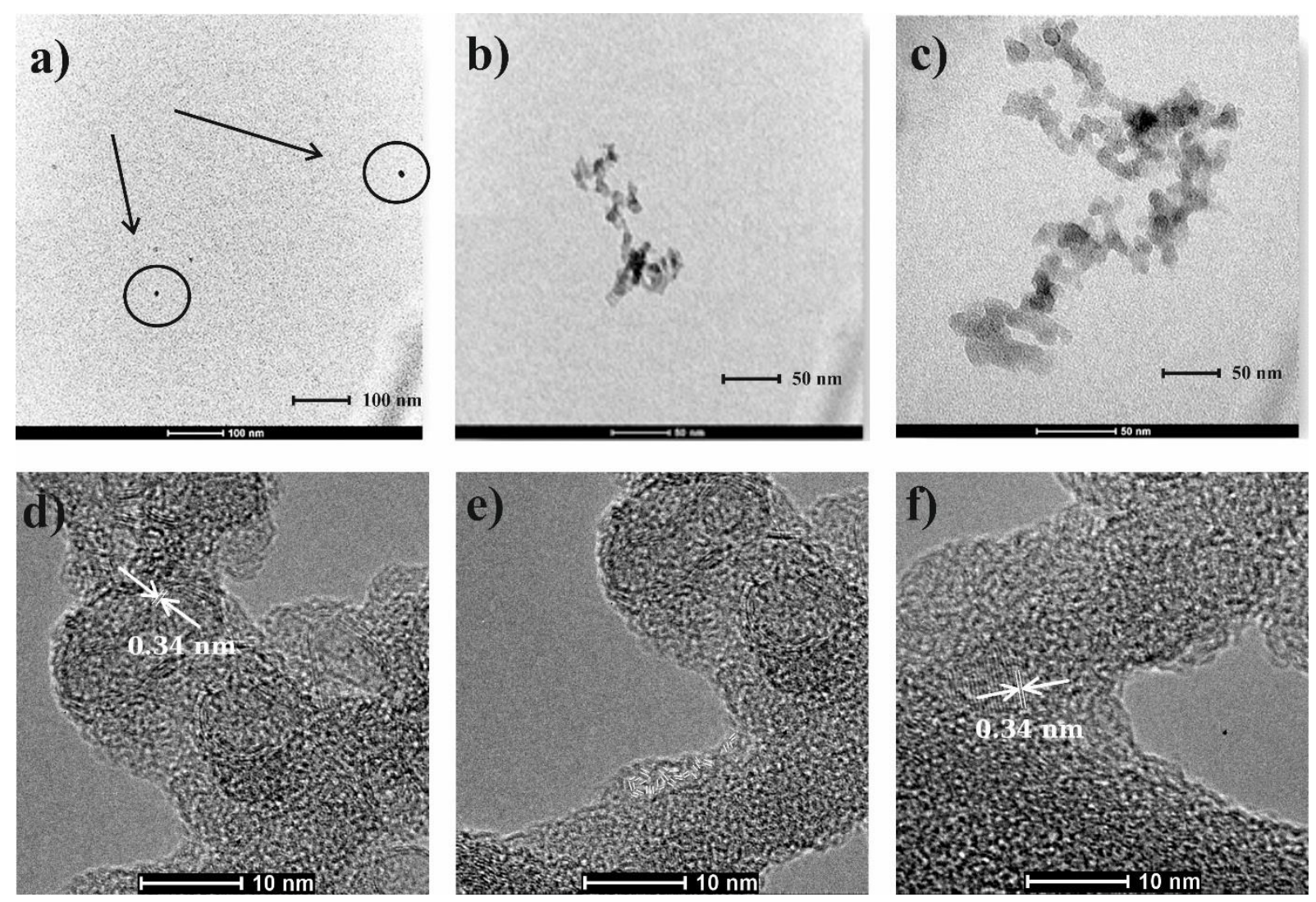

Fig.15. TEM and HRTEM images of generated particles at a) primary particles $\left(0.7 \mathrm{~J} \mathrm{~cm}^{-2}\right)$ and b) and c) fractal aggregates ( 0.9 and $2.5 \mathrm{~J} \mathrm{~cm}^{-2}$ )

To further prove that the generated particles are suitable for modelling real ambient CPM, their Raman spectra were also investigated. The Raman spectrum of the laser-generated soot aerosol is displayed on Fig. 16. The Raman spectrum showed two broad and strongly overlapping peaks with maximum intensities at around $1350 \mathrm{~cm}^{-1}$ and at around $1585 \mathrm{~cm}^{-1}$ (first-order) and one individual peak with relatively lower intensity positioned between 2700 and $3500 \mathrm{~cm}^{-1}$ (second order, not presented on the figure). The feature around $1585 \mathrm{~cm}^{-1}$ designated to $\mathrm{G}$ (graphite) peak indicates the fundamental mode of a graphite crystal, while the peak around $1350 \mathrm{~cm}^{-1}$ marks the D (disordered) lines mostly associated with amorphous or randomly oriented (turbostratic) graphene layer structures. Fig. 16. also shows the further analysis of the first-order spectrum by classifying all first-order brands by a multipeak fitting algorithm (G and D1-D4).

Results of the TEM, HR-TEM and Raman spectrum experimentally demonstrated that the morphology of the laser-generated soot aerosol is a good model of real carbonaceous atmospheric particulate originating from, e.g. diesel exhaust or kerosene flame (Park et al., 
2004; Fruhstorfer and Niessner, 1994; Randall and Vander, 2010; Tumolva et al., 2010; Song et al., 2004).

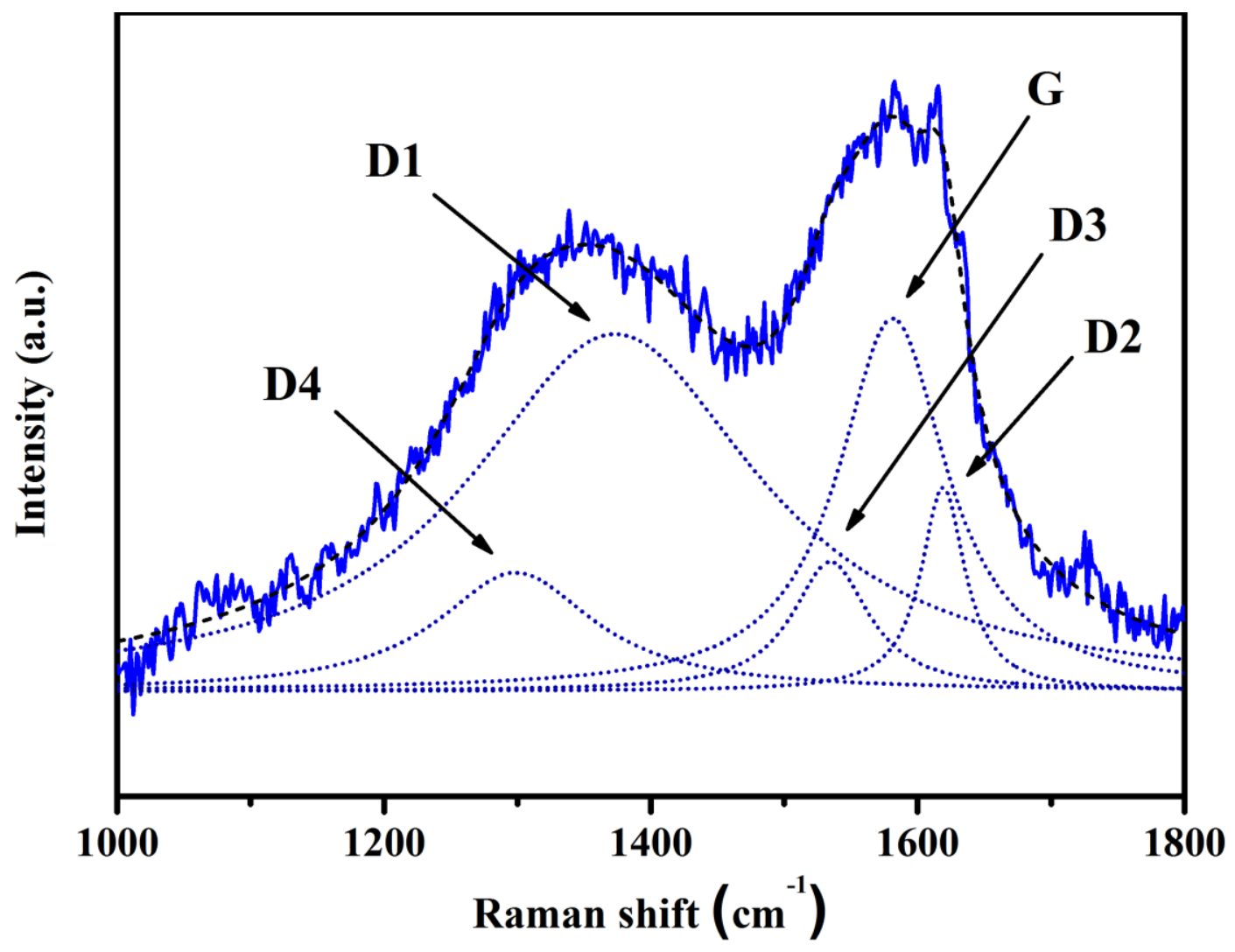

Fig. 16. First-order Raman spectra and its mode structure: $G$ and $D(D 1-D 4)$ modes represents the graphite and the disordered multi modes. The solid line represents the measured data, while the scattered line represents the fitted curves 


\section{Related thesis statement}

T1. I investigated the size distribution, morphology and microstructure of CPM generated from a graphite target by laser ablation. This CPM generating setup ensures a unique possibility for evolving particles with various microphysical parameters and morphology. The tunable parameters of the setup are fluence of laser excitation, flow rate and composition of carrier gas in the ablation chamber. Each parameter can be independently controlled. Generating parameters can model temperature of ignition, physical aging and occurring atmospheric processes, respectively. I experimentally proved that generated carbonaceous particulate matter models real atmospheric soot well. 


\subsection{INVESTIGATION OF DIESEL EMITTED CARBONACEOUS PARTICULATE MATTER}

Diesel exhaust is a complex mixture of versatile components in various mixing states. Diesel soot particles are of immense variety regarding size distribution, morphology and chemical composition. Their characteristics strongly depend on the technical parameters and the operating conditions of the engine as well as the chemical composition of the applied fuel. The mixing state (the ratio of non-volatile elemental carbon to volatile carbonaceous particulate matter) of diesel emitted carbonaceous particulate matter (DPM) has significant effect on their climatic and human health too (Bond et al., 2013; Pöschl, 2003; Cheng, 2013). Since DPM is always in thermal equilibrium with its gas ambient at local temperature (even in a dynamically changed reactive and turbulent exhaust atmosphere), ensuring proper sampling and measurement conditions to investigate the mixing state of DPM is deemed essential to study the versatile impact of that. This is one of the major challenge in this field in our time.

Although the blending rate of biodieselin diesel fuels is strictly regulated in EU countries, the effect of biodiesel content to petroleum based diesel fuel on DPM emission measured under comparable measurement conditions is still rarely available in the literature (Popovicheva et al., 2014; Uhrner et al., 2011; Rothenbacher et al., 2008; Bukowiecki et al., 2012; Liu et al., 2007; Abdul-Khalek et al., 1998; Ahlvik et al., 1998; Trapel et al., 2005; Mathis et al., 2004; Steiner et al., 2013). Biodiesel to diesel ratio of the utilized fuel can influence both regulated (number and mass concentration) and non-regulated parameters (size distribution and mixing state) of DPM. Therefore, the detailed investigation of these parameters in the function of biodiesel content of petroleum-based fuel are concurrent issues in the fields of climate and air quality research as well.

In this section I present the results of a measurement campaign focusing on characterizing diesel emitted CPM at a standardized engine test bench and an adjunct dilution chamber. I studied number concentration and size distribution of diesel emitted CPM in the function of engine operating conditions using various biodiesel and diesel blends. I also investigated the thermal evolution of DPM under various measurement conditions. 


\subsubsection{MEASUREMENT SETUP}

The measurements were carried out in the setup displayed on Fig. 17.

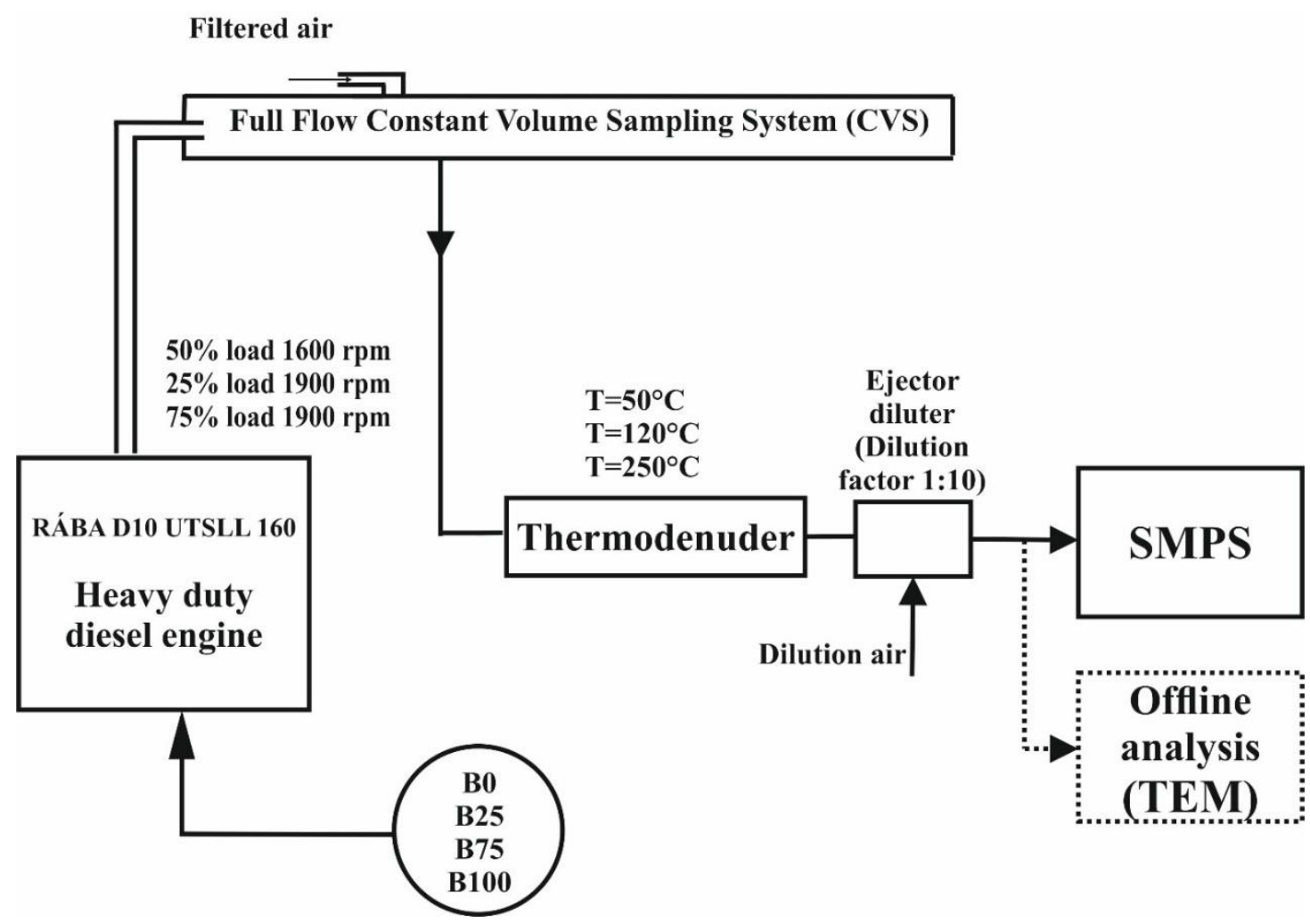

Fig. 17. Measurement setup of diesel emitted carbonaceous particulate matter investigations

In this set-up, the exhaust of a RABA D10 UTSLL 160 heavy duty diesel engine was measured. Characteristic parameters of the engine are summarized in Table 2. 
Table 2. Characteristic parameters of the RABA D10 UTSLL 160 engine

\begin{tabular}{cc}
\hline Parameter & Value \\
\hline bore & $120.5 \mathrm{~mm}$ \\
\hline stroke & $150 \mathrm{~mm}$ \\
\hline number of cylinders & 6 \\
\hline engine layout & inline \\
\hline compression ratio & 15.2 \\
\hline displacement & $10350 \mathrm{~cm}^{3}$ \\
\hline injection & direct injection \\
\hline fuel supply system & Bosch \\
\hline charging & yes \\
\hline rated power & $160 \mathrm{~kW} / 1900 \mathrm{rpm}$ \\
\hline rated torque & $920 \mathrm{Nm} / 1600 \mathrm{rpm}$ \\
\hline
\end{tabular}

Diesel emission was led through the full flow constant volume sampling (CVS) system designed for the characterisation of diesel emission according to the UN ECE Vehicle Regulation no. 49 (Revision 2). The detailed description of the full flow CVS technique can be found in the Regulation no. 49 (ECE, 2000), however a brief review is given here as well. The engine tailpipe was connected to the inlet of the CVS system. Following that the exhaust streamed to the centre of the dilution chamber through a 120 -mm-inner-diameter tube. The inner diameter of the tunnel was $600 \mathrm{~mm}$. Primary dilution of the exhaust was carried in the dilution tunnel by room temperature filtered air. Primary diluted exhaust was sampled from the centre of the tunnel ( $6000 \mathrm{~mm}$ from the inlet). Exhaust mass flow rates and dilution factors used during the measurement points are presented in Table 3. Note that abbreviations for fuel types as well as the chemical composition of pure fuels are defined later in the text (Table 5.). 
Table 3.: Mass flow rates of the sampled exhaust and primary dilution factors

\begin{tabular}{|c|c|c|c|c|c|c|c|c|c|}
\hline & \multicolumn{3}{|c|}{ Engine operating condition 1} & \multicolumn{3}{|c|}{ Engine operating condition 2} & \multicolumn{3}{|c|}{ Engine operating condition 3} \\
\hline $\begin{array}{c}\text { Type } \\
\text { of } \\
\text { fuel }\end{array}$ & $\begin{array}{c}\text { Mass } \\
\text { flow of } \\
\text { exhaust } \\
\text { gas } \\
{[\mathrm{kg} / \mathrm{h}]}\end{array}$ & $\begin{array}{c}\text { Mass } \\
\text { flow of } \\
\text { diluted } \\
\text { exhaust } \\
\text { gas } \\
{[\mathrm{kg} / \mathrm{h}]}\end{array}$ & $\begin{array}{c}\text { Primary } \\
\text { dilution } \\
\text { factor }\end{array}$ & $\begin{array}{c}\text { Mass } \\
\text { flow of } \\
\text { exhaust } \\
\text { gas } \\
{[\mathrm{kg} / \mathrm{h}]}\end{array}$ & $\begin{array}{c}\text { Mass } \\
\text { flow of } \\
\text { diluted } \\
\text { exhaust } \\
\text { gas } \\
{[\mathrm{kg} / \mathrm{h}]}\end{array}$ & $\begin{array}{c}\text { Primary } \\
\text { dilution } \\
\text { factor }\end{array}$ & $\begin{array}{c}\text { Mass } \\
\text { flow of } \\
\text { exhaust } \\
\text { gas } \\
{[\mathrm{kg} / \mathrm{h}]}\end{array}$ & $\begin{array}{c}\text { Mass } \\
\text { flow of } \\
\text { diluted } \\
\text { exhaust } \\
\text { gas } \\
{[\mathrm{kg} / \mathrm{h}]}\end{array}$ & $\begin{array}{r}\text { Primary } \\
\text { dilution } \\
\text { factor }\end{array}$ \\
\hline B0 & 470.3 & 5210.9 & 10.081 & 668.2 & 6165.5 & 8.227 & 946.4 & 7690.9 & 7.127 \\
\hline $\mathbf{B} 25$ & 467.8 & 5208.7 & 10.134 & 674.3 & 6125.9 & 8.085 & 949 & 7686.9 & 7.1 \\
\hline B75 & 469.3 & 5231.5 & 10.147 & 655.8 & 6129.7 & 8.347 & 936.9 & 7599.3 & 7.111 \\
\hline B100 & 473.4 & 5216.3 & 10.019 & 665.4 & 6140.2 & 8.228 & 934.9 & 7682.3 & 7.218 \\
\hline
\end{tabular}

As particle concentration is primarily diluted exhaust exceeded the measurement range of the applied measurement instrument, exhaust was further diluted by a factor of 10 by an ejector diluter (Palas GmbH VKL 10).

Mixing state of the diluted exhaust were investigated by taking advantage of the different thermal stability of the volatile and non-volatile components using termodenuder (TD) unit. The basic operation principle of TD was described in detailed in many other studies (Burtscher et al., 2001, Fierz et al., 2007; Stevanovic et al., 2015). The schematic view of the Burtscher-type thermodenuder is shown in Fig. 18. Briefly, volatile material can be removed from the exhaust by the first module of TD operated at given temperatures. Subsequently, evaporated species are adsorbed by an activated carbon filter at the second section of TD. Following that the SD of the remaining particulate assembly associated with a given temperature can be investigated under steady state measurement conditions (Burtscher et al., 2001; Fierz et al., 2007). 


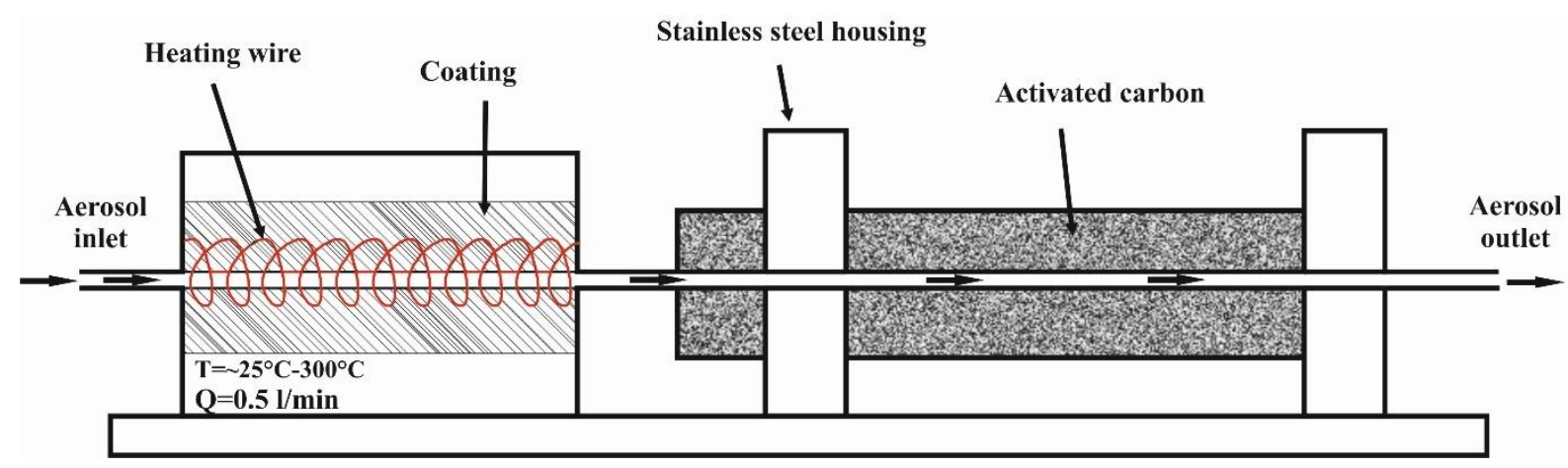

Fig. 18. Schematic graph of a Burtscher-type thermodenuder

I applied a customized version of a Burtscher-type TD unit for our measurements. The Burtscher-type TD is originally applicable for diesel exhaust measurements where high volatile matter content is expected (Burtscher et al., 2001). Our unit was proportioned for $0.31 \mathrm{~min}^{-1}$ flow rate to ensure the isokinetic conditions for the SMPS measurements. Originally, the adsorption efficiency of the TD developed by Burtscher et al. (2001) was increased by an active cooling system in which ambient air was led through an activated charcoal during operation. However, this methodological solution can cause significant thermophoretic losses due to the fast temperature drop inside the tube (Fierz et al., 2007). Therefore, to minimize these losses we reduced the length of the coupling tube between the adsorber and desorber module as well as we thermally isolated the adsorber tube neglecting additional cooling of the activated charcoal. To ensure unchanged adsorption efficiency during the measurements, the activated charcoal was regenerated between the measurement phases.

Particle penetration efficiency at different operating temperatures of our customized TD unit was quantified by well-defined measurement protocol using diffusion dried $\mathrm{NaCl}$ particles (Burtscher et al., 2001) as follows. Size distribution and number concentration of the $\mathrm{NaCl}$ particles were measured before and after the TD at different temperatures, while for reference, a simple connector tube was used having the exact same dimensions than that of the one originally implemented into the TD (Stevanovic et al., 2015). Due to our slight modifications, in case of our TD, smaller temperature drop was observed in the last section of the desorber unit compared to the original one designed by Burtscher et al., 2011. This slightly decreased thermophoretic losses but did not yield remarkable improvement regarding the particle diffusion losses of the TD.

Two measurement modes were applied during the tests. In the first mode, diesel emission was investigated in the function of engine operating condition and fuel type. During 
these measurements, the TD was operated at $50^{\circ} \mathrm{C}$ (reference temperature). In the second mode, when the thermal behaviour of the exhausted particulate matter was investigated, the TD was heated up to 120 and $250^{\circ} \mathrm{C}$, subsequently. To investigate the effect of different biodiesel blends on the properties of the emitted DPM, different fuel blends were prepared from commercially available diesel EN (European Norm) 590 (B0) and pure specified biodiesel fuel (Fatty Acid Methyl Esther (FAME), EN 14214) (B100). The characteristic parameters of pure fuels are listed in Table 4.

Table 4. Characteristic parameters of the fuels (Szabados et al., 2015)

\begin{tabular}{cccccc}
\hline $\begin{array}{c}\text { Fuel } \\
\text { type }\end{array}$ & $\begin{array}{c}\text { Kensity }\left[\mathbf{k g} / \mathbf{d m}^{\mathbf{3}}\right] \\
\mathbf{1 5}^{\circ} \mathbf{C}\end{array}$ & $\begin{array}{c}\text { vower } \\
{\left[\mathbf{m m}^{2} / \mathbf{s}\right] \text { at }} \\
\mathbf{4 0}^{\circ} \mathbf{C}\end{array}$ & $\begin{array}{c}\text { Falue } \\
{[\mathbf{M J} / \mathbf{k g}]}\end{array}$ & $\begin{array}{c}\text { Flash point } \\
\text { (open cup }\end{array}$ & $\begin{array}{c}\text { Flash point } \\
(\text { closed cup })\end{array}$ \\
\hline $\begin{array}{c}\left.{ }^{\circ} \mathbf{C}\right] \\
\text { method) }\end{array}$ & {$\left[{ }^{\circ} \mathbf{C}\right]$} \\
\hline $\begin{array}{c}\text { Diesel } \\
(B 0)\end{array}$ & 0.84 & 2.98 & 42.12 & 90 & 70 \\
\hline FAME & 0.88 & 5.05 & 36.29 & 189 & 201 \\
$(B 100)$ & & & & \\
\hline
\end{tabular}

Applied engine operating conditions during the measurements were adapted from the 13-mode steady state cycle of UN ECE Vehicle Regulation no. 49 (Revision 2). Table 5. gives and overview of utilized measurement conditions including fuel blends, operating conditions and TD temperatures. 
Table 5. Applied fuel types and measurements conditions

\begin{tabular}{cc}
\hline$\#$ & Fuel type \\
\hline B0 & $100 \%$ Diesel \\
\hline B25 & $25 \%$ FAME \\
\hline B75 & $75 \%$ FAME \\
\hline B100 & $100 \%$ FAME \\
\hline$\#$ & $\begin{array}{c}\text { Engine operating } \\
\text { condition }\end{array}$ \\
\hline $\mathbf{1 .}$ & $50 \%$ load, $1600 \mathrm{rpm}$ \\
\hline $\mathbf{2 .}$ & $25 \%$ load, $1900 \mathrm{rpm}$ \\
\hline $\mathbf{3 .}$ & $75 \%$ load, $1900 \mathrm{rpm}$ \\
\hline$\#$ & $\begin{array}{c}\text { Thermodenuder } \\
\text { temperature }\end{array}$ \\
\hline T1 & $50^{\circ} \mathrm{C}$ \\
\hline T2 & $120^{\circ} \mathrm{C}$ \\
\hline T3 & $250^{\circ} \mathrm{C}$ \\
\hline
\end{tabular}

Methodology and instrumentation applied for online measuring number concentration and size distribution data are presented and described in Section 4.1.2. Offline methodology for studying morphology and microstructure of diesel emitted particles (TEM, HRTEM and ED) are described in detail in Section 4.2.1. For comparison purposes, data demonstrated throughout this work are dilution and particle loss corrected. 


\subsubsection{DYNAMIC CHANGES AT DIFFERENT ENGINE OPERATING CONDITIONS AND FUEL} TYPES.

I investigated the effect of engine operating condition on size distribution total number concentration of diesel emitted CPM. Per that I measured SD in the function of the applied engine operational conditions regarding the four fuel types. All measured size distributions could be fitted with the lognormal function (Heintzenberg, 1994) and described with characteristic parameters CMD, GSD and TNC. Measured SD, fitted curves and characteristics fitted parameters are demonstrated in Fig. 19. and Table 6.

CMD showed a slight increase in case of B0 and B25 in the function of engine operating condition. Considering B75, CMD values did not significantly depend either on the operating condition of the engine. In case of B100 CMD slightly increased at operating condition 2 compared to engine operating condition 1 , while a modest decrease between engine operating conditions 2 to 3 . However, GSD increased in the function of engine operation condition regarding all fuel blends.
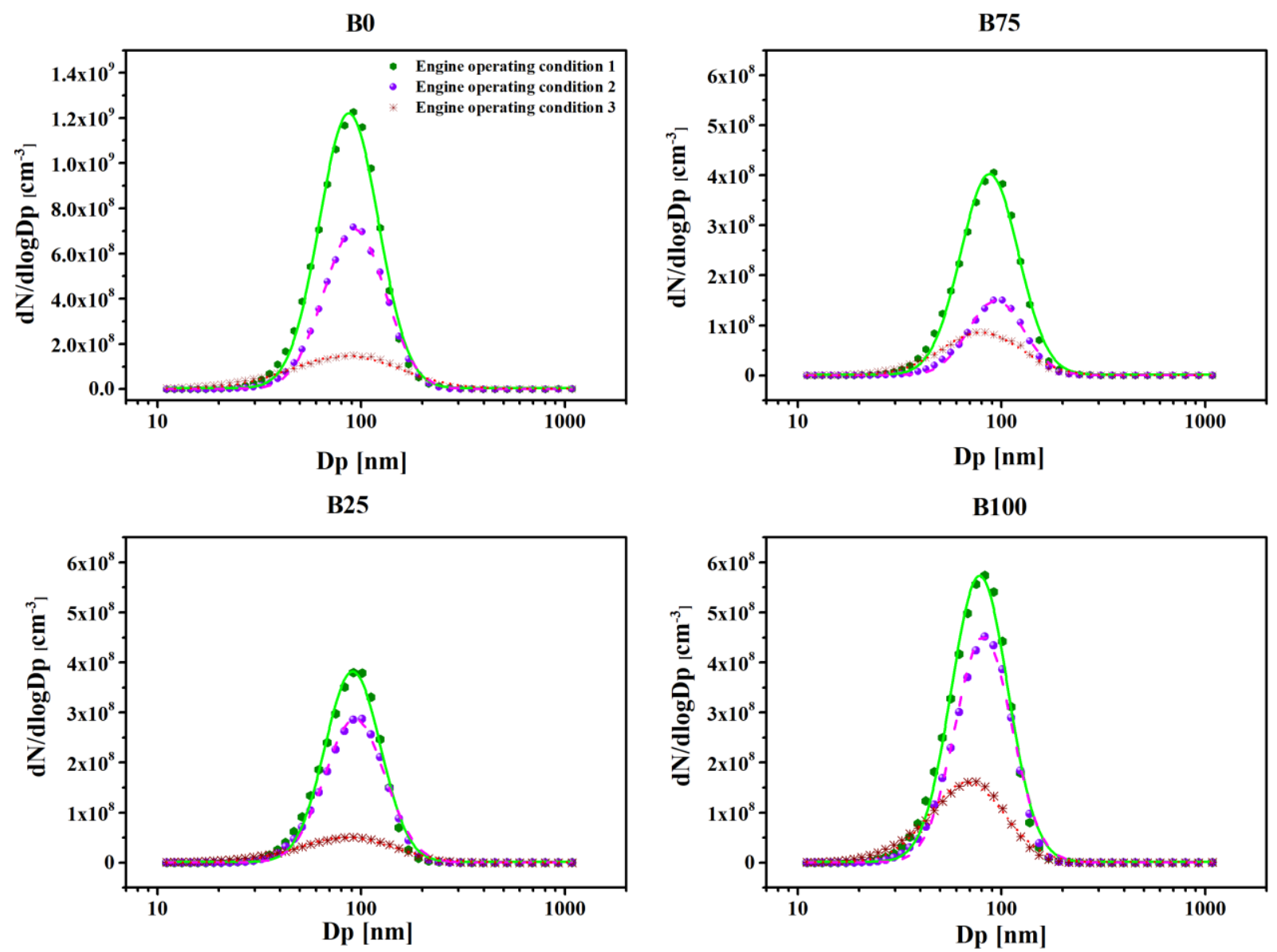

Fig. 19. Measured size distribution curves in case of the studied engine operating conditions and 4 fuel blends 
Table 6. Summary of the characteristic parameters of the measured SD curves at all engine operational conditions and fuel types

\begin{tabular}{|c|c|c|c|}
\hline \multicolumn{4}{|c|}{ Engine operating condition 1} \\
\hline Fuel type & $\begin{array}{l}\text { CMD } \\
{[\mathrm{nm}]}\end{array}$ & $\begin{array}{c}\text { Total number } \\
\text { concentration }\left({ }^{*} 10^{8}\right) \\
{\left[\mathrm{cm}^{-3}\right]}\end{array}$ & $\begin{array}{c}\text { Geometric } \\
\text { standard } \\
\text { deviation } \\
\text { [nm] }\end{array}$ \\
\hline B0 & $98.7 \pm 0.55$ & 4.51 & $73.7 \pm 0.48$ \\
\hline $\mathrm{B} 25$ & $101.8 \pm 0.71$ & 3.09 & $69.6 \pm 0.62$ \\
\hline B75 & $106.3 \pm 0.68$ & 2.16 & $75.3 \pm 0.56$ \\
\hline $\mathrm{B} 100$ & $88.1 \pm 0.59$ & 4.67 & $61.6 \pm 0.60$ \\
\hline \multicolumn{4}{|c|}{ Engine operating condition 2} \\
\hline Fuel type & $\begin{array}{c}\text { CMD } \\
{[\mathrm{nm}]}\end{array}$ & $\begin{array}{c}\text { Total number } \\
\text { concentration }\left({ }^{*} 10^{8}\right) \\
{\left[\mathrm{cm}^{-3}\right]}\end{array}$ & $\begin{array}{c}\text { Geometric } \\
\text { standard } \\
\text { deviation } \\
\text { [nm] }\end{array}$ \\
\hline B0 & $107.6 \pm 0.57$ & 2.80 & $84.8 \pm 0.45$ \\
\hline $\mathrm{B} 25$ & $107.3 \pm 0.88$ & 1.83 & $76.0 \pm 0.73$ \\
\hline B75 & $105.3 \pm 0.57$ & 1.21 & $72.5 \pm 0.55$ \\
\hline $\mathrm{B} 100$ & $91.1 \pm 0.56$ & 3.63 & $62.9 \pm 0.55$ \\
\hline \multicolumn{4}{|c|}{ Engine operating condition 3} \\
\hline Fuel type & $\begin{array}{l}\text { CMD } \\
{[\mathrm{nm}]}\end{array}$ & $\begin{array}{c}\text { Total number } \\
\text { concentration }\left(* 10^{8}\right) \\
{\left[\mathrm{cm}^{-3}\right]}\end{array}$ & $\begin{array}{c}\text { Geometric } \\
\text { standard } \\
\text { deviation } \\
\text { [nm] }\end{array}$ \\
\hline B0 & $125.1 \pm 3.13$ & 1.03 & $132.9 \pm 1.70$ \\
\hline $\mathrm{B} 25$ & $108.2 \pm 1.13$ & 0.53 & $108.0 \pm 0.78$ \\
\hline B75 & $106.9 \pm 0.87$ & 0.34 & $91.0 \pm 0.66$ \\
\hline $\mathrm{B} 100$ & $83.5 \pm 0.92$ & 1.71 & $74.0 \pm 0.89$ \\
\hline
\end{tabular}


TNC and TVC variated in the function of both engine operating condition and fuel type as seen in Table 7. and plotted on Fig. 20. Total volume of diesel emitted particles was deduced simply from TNC assuming spherical particles. Since diesel soot particles generally have complex fractal-like structures, this approach means limitations in data interpretations. Still, it is a generally accepted approach especially considering the discussion of relative deviations (Ban-Weiss et al., 2010; Rissler et al., 2012). TNC and TVC both decreased with increasing revolution per minute and rated torque regardless of the mixing ratio of the applied fuels.

Surprisingly, FAME content of the fuel blend did not linearly affect the concentration of diesel emission. TNC and TVC both had a minimum in case of the B75 fuel. This curious behaviour is not consistent with most of the existing data in the literature. However, since, the operating condition of the diesel engine is not optimized for high FAME content and since legal regulation restricts maximum FAME content of diesel fuels below 10\%, the available studies focus mainly on intercomparing diesel fuel with pure FAME or with limited FAME content (Abdul-Khalek et al.,1999; Burtscher, 2005; Lloyd and Cackette, 2001; Cheng, 2013). Detailed analysis of biodiesel blends with high mixing ratio is rather limited in literature. (Puzun et al., 2011; XuSheng et al., 2009; Turrio-Baldassarri et al., 2004; Tinsdale et al., 2010; Lin et al., 2008). Based on these studies a near-linear relation is generally expected between the mixing ratio of biofuel and emitted concentration. However, similar non-linear behaviour was recognised by Lin et al., 2008 but for diverse types of biofuels regardless of a detailed explanation of the possible theoretical background (Lin et al., 2008). Moreover, many earlier studies experimentally confirmed that the emission characteristics of different diesel engines can vary even if the same operating conditions and fuels are applied (Abdul-Khalek et al.,1999; Burtscher, 2005; Lloyd and Cackette, 2001; Cheng, 2013).

TNC was higher, while TVC was lower in case of B100 fuel compared to the commonly used B0 fuel at all engine operating conditions (Table 7, Fig. 20.). Similarly, the variation of TNC exceeded $25 \%$ after switching from engine operating condition 1 to 2 in case of B100, while changes in TVC between engine operating condition 1 and 2 remained below $12 \%$ (Fig. 22). These phenomena can be explained by the changes in particle population statistics. In the first case, due to the differences of CMD values alongside with the nearly identical GSD and TNC, lower TVC was calculated. Similarly, in the second case, although CMD was higher at engine operating condition no. 2 than at engine operating condition no.1, lower TNC together with higher GSD rearranged the relative weight of number and volume concentrations at each 
size bins issuing negligible deviation in total volume. Relative changes in TNC and TVC compared to B0 at all engine operating conditions are summarized in Table 7.

a)

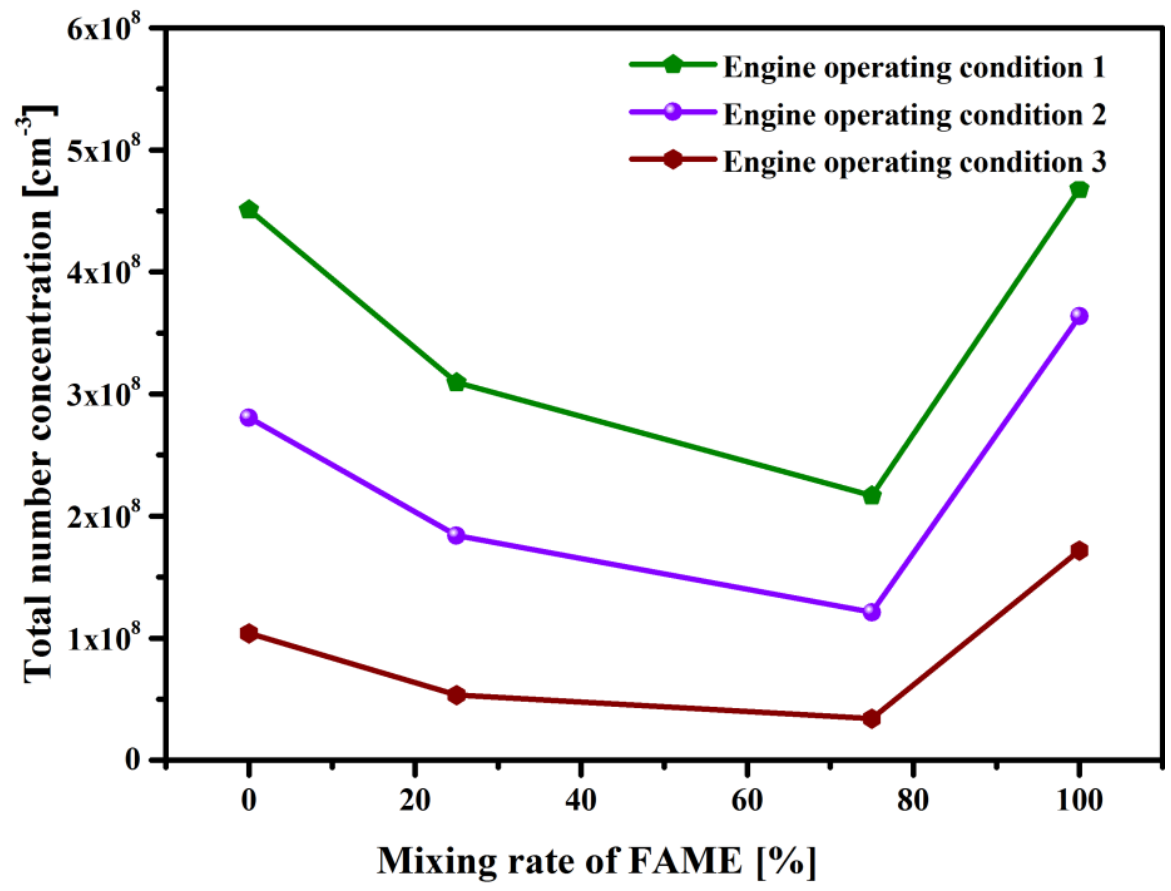

b)

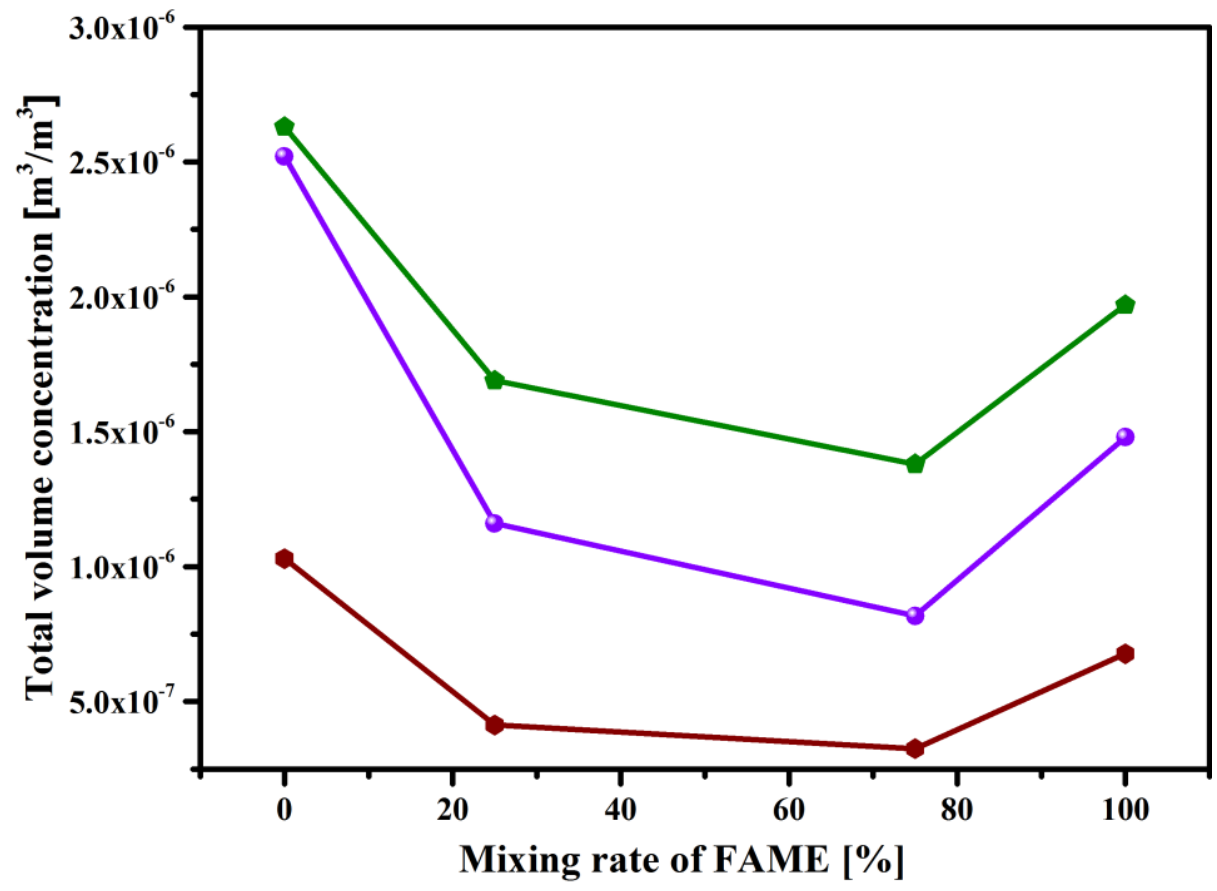

Figure 20. Changes in total number (a) and volume concentration (b) in the function of fuel mixing rate and engine operating condition 
Table 7. Summary of the relative changes in TNC and TVC measured at all the presented engine operating conditions and fuel types

\begin{tabular}{cccc}
\hline \multicolumn{2}{c}{ a) } & Relative changes in particle number concentration [\%] \\
\hline Fuel type & $\begin{array}{c}\text { Engine } \\
\text { operating } \\
\text { condition no.1. }\end{array}$ & $\begin{array}{c}\text { Engine } \\
\text { operating } \\
\text { condition no.2 }\end{array}$ & $\begin{array}{c}\text { Engine operating } \\
\text { condition no.3 }\end{array}$ \\
\hline B0 & - & - & - \\
\hline B25 & -30.40 & -33.44 & -47.68 \\
\hline B75 & -50.95 & -55.83 & -66.20 \\
\hline B100 & 4.76 & 30.61 & 66.22 \\
\hline & b) & Relative changes in total volume concentration [\%] & Engine operating \\
& Engine & Engine & condition no.3 \\
\hline Fuel type & operating & operating & - \\
\hline B0 & condition no.1. & condition no.2 & -55.79 \\
\hline B25 & - & - & -74.72 \\
\hline B75 & -30.57 & -37.99 & -42.51 \\
\hline B100 & -31.61 & -60.47 & \\
\hline
\end{tabular}




\subsubsection{THERMAL BEHAVIOUR OF DIESEL EMITTED CPM}

I investigated the thermal behaviour of diesel emitted $\mathrm{CPM}$ at three temperatures $\left(50^{\circ} \mathrm{C}\right.$, $120^{\circ} \mathrm{C}$ and $250^{\circ} \mathrm{C}$ ) using our in-house developed thermodenuder. The first temperature point $\left(50^{\circ} \mathrm{C}\right)$ corresponds to the reference "non-heated" condition defined in UN ECE Vehicle Regulation no. 49 (Revision 2). The size distribution measured at different engine conditions and fuel types at three different temperatures are described in Table 8 and 9 and are plotted in Fig. 21. SD curves are corrected for the thermodenuder losses.

During the $50^{\circ} \mathrm{C}$ to $120^{\circ} \mathrm{C}$ temperature transition, number concentration remarkably decreased in case of all engine operating conditions and fuel types. Also, shifts of curve peak positions were observed in both directions in the function of measurement conditions however, without a clear trend. Changes observed during the first transition have already been observed in many earlier works and explained by the differences in thermochemical reactiveness of individual volatile particles and that of core-shell microstructures (Burtscher et al., 2001; Burtscher, 2005; Cheng, 2013; Guo et al., 2014). Individual volatile particulates having low thermochemical refractiveness completely, while the core-shell microstructures only partly vaporized. The former is thought to have resulted in a particulate number decrement, while the later one most likely caused the shift of SD curves. Although according to literature, most particles in the accumulation mode are solid and cannot be completely vaporized at $120^{\circ} \mathrm{C}$ (Kittleson, 1998). Nevertheless, slight shifts in peak position really support the theory of the evaporation of substances previously adsorbed or condensed on soot cores at lower temperature in the CVS system. Size independent particle losses might also indicate another dominant phenomenon: limited pyrolysis of particles having only partial or no graphitic microstructure (Lapuerta et al., 2008a, 2008b; Turrio-Baldassarri et al., 2004; Tinsdale et al., 2010; Lin et al., 2008). 

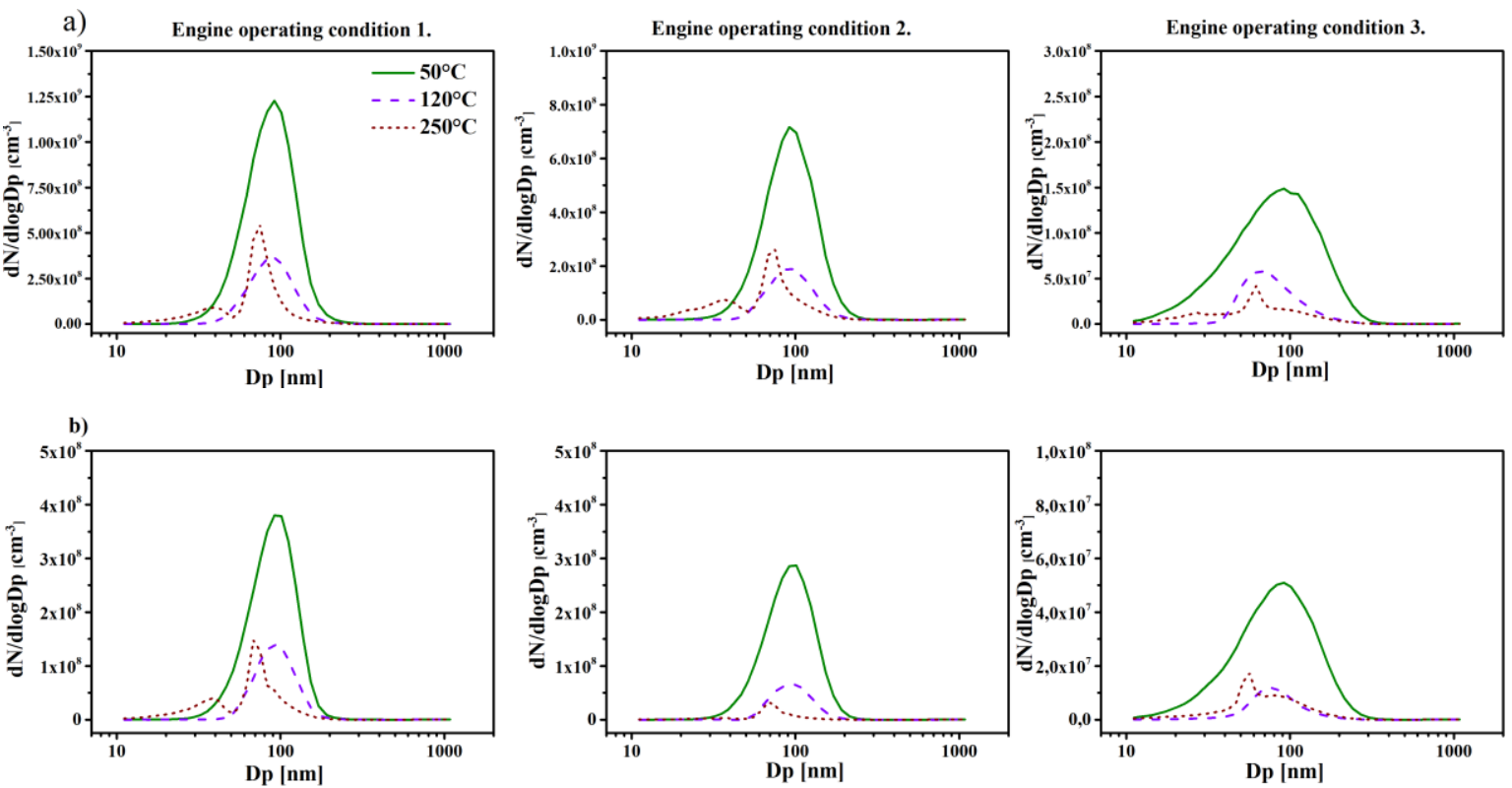

c)
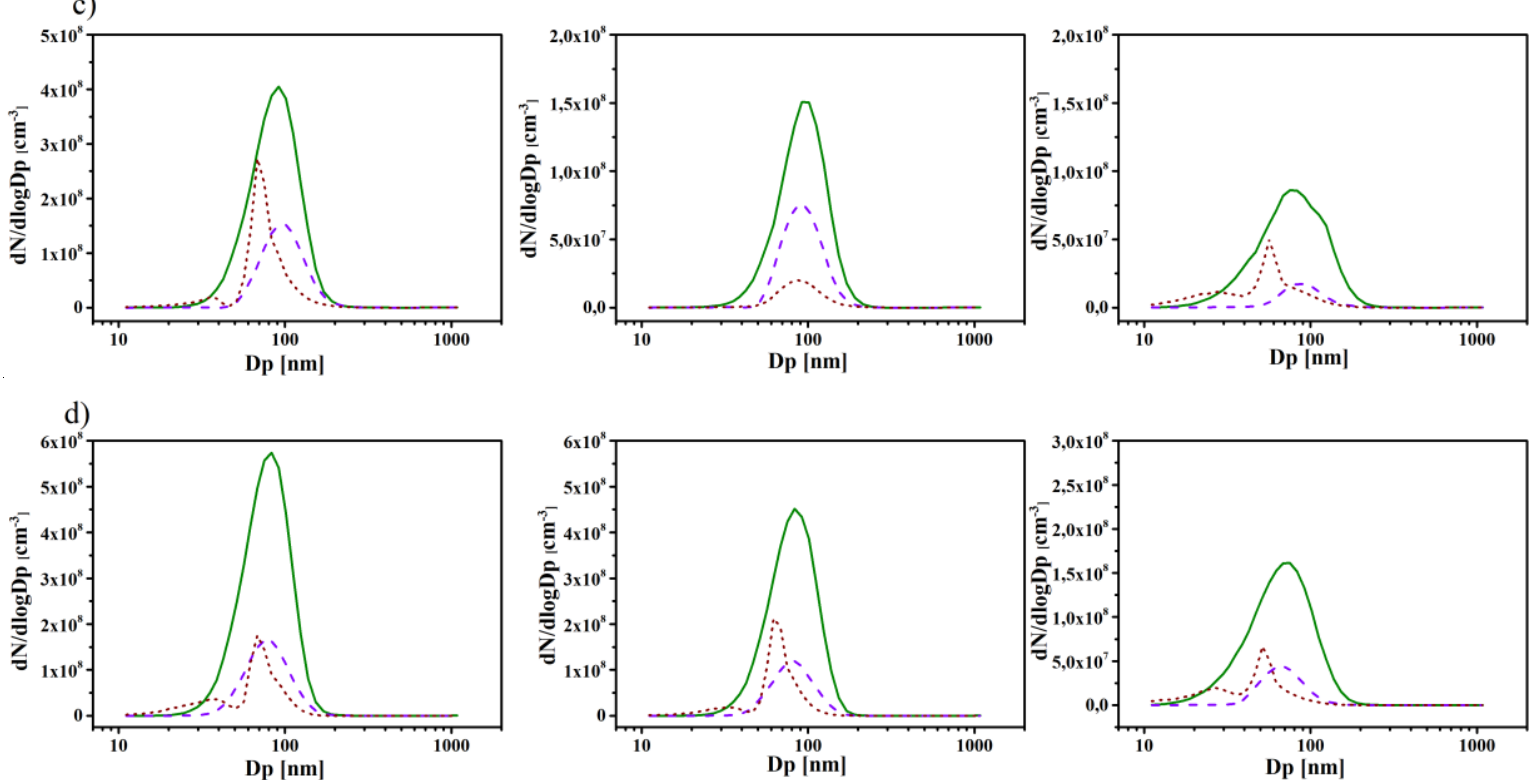

Figure 21. The size distribution in number representation measured at different engine operating condition and fuel types at three different temperatures ( $a: B 0, b: B 25, c: B 75, d$ : B100) 
Table 8. The statistical summary of the characteristic parameters of the measured distributions at $120^{\circ} \mathrm{C}$.

\begin{tabular}{|c|c|c|c|}
\hline \multicolumn{4}{|c|}{ Engine operating condition no. 1 . } \\
\hline Fuel type & $\begin{array}{l}\text { CMD } \\
{[\mathrm{nm}]}\end{array}$ & $\begin{array}{c}\text { Total number } \\
\text { concentration }\left({ }^{*} 10^{8}\right) \\
{\left[\mathrm{cm}^{-3}\right]}\end{array}$ & $\begin{array}{c}\text { Geometric } \\
\text { standard } \\
\text { deviation } \\
\text { [nm] }\end{array}$ \\
\hline $\mathrm{B} 0$ & 95.66 & 1.22 & 65.84 \\
\hline $\mathrm{B} 25$ & 99.25 & 0.97 & 64.17 \\
\hline B75 & 104.22 & 1.11 & 67.49 \\
\hline B100 & 85.08 & 1.24 & 56.86 \\
\hline
\end{tabular}

Engine operating condition no. 2.

\begin{tabular}{|c|c|c|c|}
\hline Fuel type & $\begin{array}{l}\text { CMD } \\
{[\mathrm{nm}]}\end{array}$ & $\begin{array}{c}\text { Total number } \\
\text { concentration }\left(* 10^{8}\right) \\
{\left[\mathrm{cm}^{-3}\right]}\end{array}$ & $\begin{array}{c}\text { Geometric } \\
\text { standard } \\
\text { deviation } \\
\text { [nm] }\end{array}$ \\
\hline B0 & 101.34 & 0.64 & 69.61 \\
\hline $\mathrm{B} 25$ & 101.04 & 0.47 & 63.91 \\
\hline B75 & 98.10 & 0.52 & 60.05 \\
\hline B100 & 87.40 & 0.85 & 54.61 \\
\hline \multicolumn{4}{|c|}{ Engine operating condition no. 3 . } \\
\hline Fuel type & $\begin{array}{l}\text { CMD } \\
{[\mathrm{nm}]}\end{array}$ & $\begin{array}{c}\text { Total number } \\
\text { concentration }\left({ }^{*} \mathbf{1 0}^{8}\right) \\
{\left[\mathrm{cm}^{-3}\right]}\end{array}$ & $\begin{array}{c}\text { Geometric } \\
\text { standard } \\
\text { deviation } \\
\text { [nm] }\end{array}$ \\
\hline B0 & 80.69 & 0.23 & 60.64 \\
\hline $\mathrm{B} 25$ & 85.73 & 0.095 & 57.51 \\
\hline B75 & 94.68 & 0.12 & 58.15 \\
\hline B100 & 72.06 & 0.32 & 46.34 \\
\hline
\end{tabular}


During the $120^{\circ} \mathrm{C}$ to $250^{\circ} \mathrm{C}$ temperature transition, structural changes were observed resulting in bimodal SD curves in case of all engine operating conditions and fuel types (Fig. 22.). The statistical summary of the characteristic parameters of the SDs measured at $250^{\circ} \mathrm{C}$ are summarized in Table 9. Two modes were observed although with varying intensity and peak position. Both modes could be fitted with the lognormal function. This can be explained as follows. At higher temperatures, because of the fast temperature drop in the dilution system, the volatile compounds formed individual volatile particulates with most probably spherical geometry and various composition, while the condensable substances having higher molecular weight adsorbed onto the surface of soot particulates resulting in core-shell microstructures (Ishigoru et al., 1997). Therefore the small size mode was formed through homogenous condensation, while the large size submode came from heterogenous condensation. 
Table 9. The statistical summary of the characteristic parameters of the measured distributions at $250^{\circ} \mathrm{C}$. CMD stands for count median diameter.

\begin{tabular}{|c|c|c|c|c|c|}
\hline \multicolumn{6}{|c|}{ Engine operating condition no.1. } \\
\hline \multirow[t]{2}{*}{ Fuel type } & \multicolumn{2}{|c|}{$\begin{array}{l}\text { CMD } \\
{[\mathrm{nm}]}\end{array}$} & \multirow{2}{*}{$\begin{array}{c}\text { Total number } \\
\text { concentration } \\
\qquad\left(* 10^{8}\right) \\
{\left[\mathrm{cm}^{-3}\right]}\end{array}$} & \multicolumn{2}{|c|}{$\begin{array}{c}\text { Geometric standard } \\
\text { deviation } \\
{[\mathrm{nm}]}\end{array}$} \\
\hline & Mode 1 & Mode 2 & & Mode 1 & Mode 2 \\
\hline B0 & 37.9 & 76.1 & 1.20 & 21.4 & 25.1 \\
\hline $\mathrm{B} 25$ & 37.2 & 73.3 & 1.07 & 19.7 & 23.2 \\
\hline $\mathrm{B} 75$ & 37.1 & 73.3 & 1.04 & 20.2 & 25.1 \\
\hline B100 & 34.9 & 73.0 & 1.30 & 23.4 & 26.7 \\
\hline
\end{tabular}

Engine operating condition no.2.

\begin{tabular}{|c|c|c|c|c|c|}
\hline \multirow[t]{2}{*}{ Fuel type } & \multicolumn{2}{|c|}{$\begin{array}{l}\text { CMD } \\
\text { [nm] }\end{array}$} & \multirow{2}{*}{$\begin{array}{c}\text { Total number } \\
\text { concentration } \\
\left({ }^{\left.* 10^{8}\right)}\right. \\
{\left[\mathrm{cm}^{-3}\right]}\end{array}$} & \multicolumn{2}{|c|}{$\begin{array}{c}\text { Geometric standard } \\
\text { deviation } \\
{[\mathrm{nm}]}\end{array}$} \\
\hline & Mode 1 & Mode 2 & & Mode 1 & Mode 2 \\
\hline B0 & 36.6 & 75.4 & 0.76 & 24.8 & 26.8 \\
\hline $\mathrm{B} 25$ & 34.6 & 72.1 & 0.89 & 20.4 & 22.5 \\
\hline $\bar{B} 75$ & - & 94.7 & 0.90 & - & 55.4 \\
\hline $\mathrm{B} 100$ & 32.0 & 67.0 & 1.06 & 21.5 & 23.6 \\
\hline \multicolumn{6}{|c|}{ Engine operating condition 3.} \\
\hline \multirow{2}{*}{ Fuel type } & \multicolumn{2}{|c|}{$\begin{array}{l}\text { CMD } \\
{[\mathrm{nm}]}\end{array}$} & \multirow{2}{*}{$\begin{array}{c}\text { Total number } \\
\text { concentration } \\
\left({ }^{\left.* 10^{8}\right)}\right. \\
{\left[\mathrm{cm}^{-3}\right]}\end{array}$} & \multicolumn{2}{|c|}{$\begin{array}{c}\text { Geometric standard } \\
\text { deviation }\end{array}$} \\
\hline & Mode 1 & Mode 2 & & Mode 1 & Mode 2 \\
\hline B0 & 61.9 & 119.7 & 0.15 & 10.5 & 100.3 \\
\hline $\mathrm{B} 25$ & 55.3 & 88.6 & 0.31 & 11.4 & 96.4 \\
\hline $\bar{B} 75$ & 27.0 & 57.4 & 0.31 & 37.5 & 14.6 \\
\hline $\mathrm{B} 100$ & 27.5 & 53.1 & 0.29 & 20.9 & 14.5 \\
\hline
\end{tabular}

As explained above, the small size mode was most probably formed by new particle formation through homogenous condensation. Based on this, the observed structural changes 
were probably due to an occurring measurement artefact: the re-condensation of compounds previously evaporated from the surface of solid soot particles not trapped by the activated carbon in the second stage of the denuder. To minimize this phenomenon, the activated carbon was regenerated between each measurement point during thermal treatment measurements. Fig. 22. depicts relative losses (compared to baseline temperature) of total number and volume concentration.
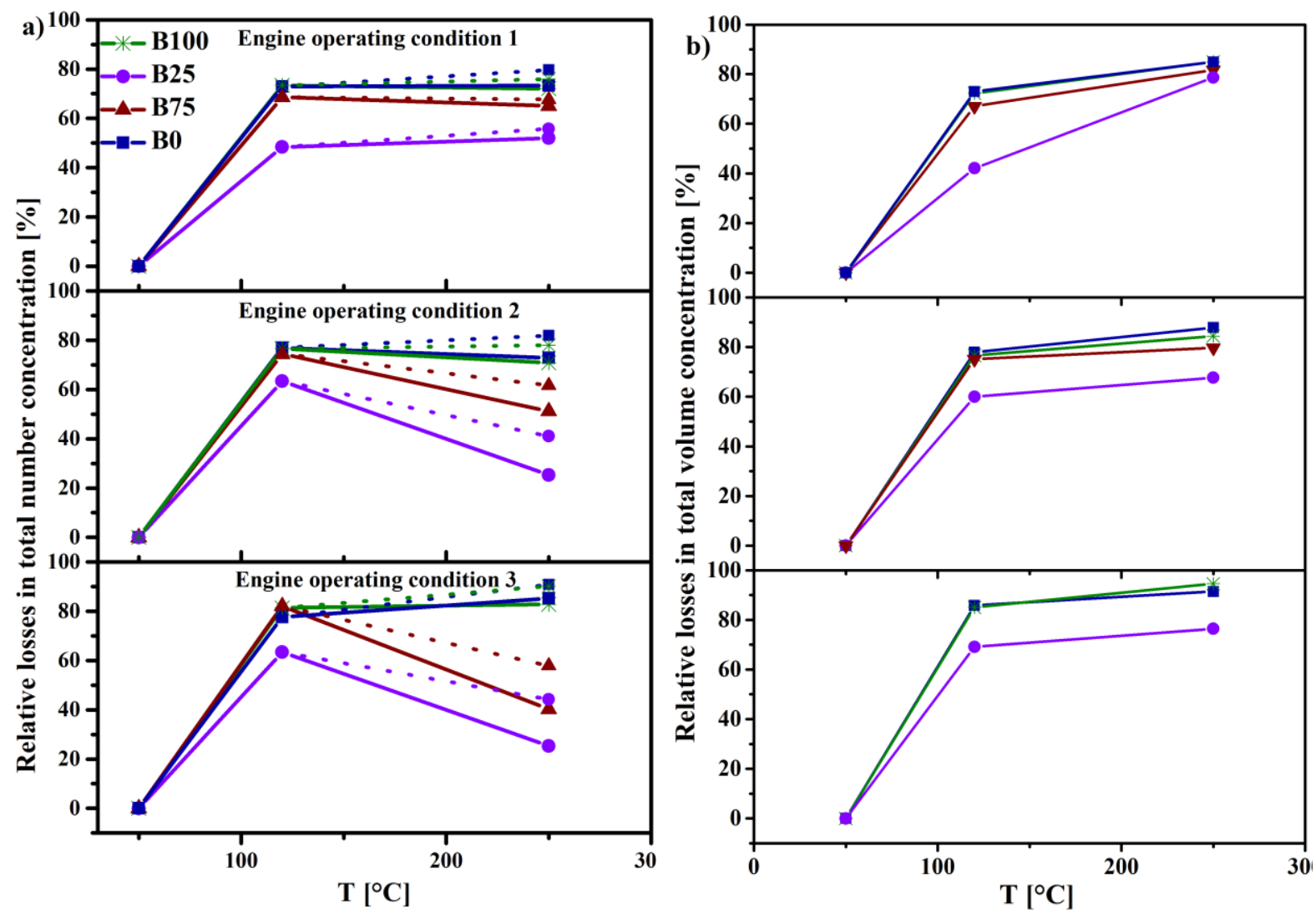

Figure 22. Relative losses of total number $(a)$ and volume $(b)$ concentration compared to baseline condition. Dotted lines represent values, where the smaller mode originating from the TD effect was neglected in calculation.

At the first temperature transition $\left(50-120^{\circ} \mathrm{C}\right)$, TNC losses reach up to $80 \%$ regarding all fuel types and engine operating conditions. However, smaller losses were noted in case of B75 for all engine operating conditions. These findings are concordant with literature data (Burtscher et al., 2001; Burtscher, 2005; Cheng, 2013; Guo et al., 2014). At the second temperature transition $\left(120-250^{\circ} \mathrm{C}\right)$, pure fuels $(\mathrm{B} 0$ and $\mathrm{B} 100)$ displayed negligible further losses regardless of engine operating condition. Nevertheless, B25 and B75 produced unexpected results at engine operating conditions 2 and 3. In these cases, higher TNC was measured compared to $120^{\circ} \mathrm{C}$. At first it might seem that the above described process of re- 
condensation is the reason behind those observations. However, if we neglect the contribution of the appearing small size modes in TNC, similar tendencies can be seen. Another physical phenomenon could be behind this behaviour. One possible theory is the fragmentation of loosely bended sub-fractal fractions (Harris and Maric, 2002; Rothenbacher et al., 2008). However, this process is more likely to be expected in case of pure FAME than in case of regular diesel or blends. Earlier studies suggested that primarily emitted particles can be fragmented due to low thermal stability adsorbates being removed from their surface even in case of commercial diesel fuel (Harris and Maric, 2002; Rothenbacher et al., 2008). Carbonaceous particles of a size big enough for this process (so-called superaggregates) have been first observed during forest wildfires in wood burning emission (Chakrabaty et al., 2014). I did not find literature proof for the presence of superaggregates in pure diesel exhaust, nonetheless it could be a possible explanation of the observed phenomenon.

To further support this interpretation, relative losses of TVC at different temperatures were also calculated (Fig. 22b.). Similar to TNC, TVC also significantly increased during the first temperature transition that is consistent with the earlier published data (Burtscher et al., 2001; Sakurai et al., 2003; Rönkkö et al., 2007). As opposed to that of TNC, the relative losses of TVC only slightly increased or remained almost constant during the second temperature transition in case of all fuel types and engine operating conditions. Accordingly, it is possible that the soot fractal aggregates or super aggregates formed when two or more primary aggregates collide with each other (Chakrabaty et al., 2014) suffered fragmentations resulting in higher particle TNC in the whole assembly but in unchanged or almost constant TVC. 


\subsubsection{MORPHOLOGY AND MICROSTRUCTURE OF DIESEL EMITTED PARTICLES}

Apart from online measurements, the morphology and microstructure of engine exhaust particles were investigated by Transmission Electron Microscopy (TEM, HRTEM) and Electron Diffraction (ED). TEM pictures presented here only serve presentation purposes and are analysed only in the context of discussing the SD data (Fig. 23 and 24.). Statistically relevant conclusion could not be drawn as only a limited number of samples were collected. Data discussion is further restrained by the fact that the number of trapped particulates can be limited or evaporation of volatile particulate from the grid by the applied beam energy can occur in case of the applied TEM methodology. No distinct characteristic particle features were noticed to variate in the function of neither engine operating condition nor fuel type. Fractal aggregates consisting of 7-10 nm primary particles were found to be dominant under all conditions that are typical for diesel emitted CPM (Kittleson, 1998). I also found some evidence of soot fractal superaggregate-like structures with more complex morphology and larger size even in case of B0 (Fig. 23.).

HRTEM images showed that primary particulates have amorphous turbostratic structure with randomly oriented graphitic domains regardless of the fuel type (Fig. 23 a, b, c). Apart from carbon structures, unidentified particle structures were also found among the samples (Fig. $23 \mathrm{~d}$, e, f). The electron diffraction pattern of the amorphous turbostratic particulates consists of diffuse rings implying the lack of crystallinity. Randomly oriented graphitic domains cannot be differentiated in the images as they are masked by diffuse diffraction of the amorphous particles (and the carbon film of the sample holder grid). In contrast to diffuse diffraction of carbon structures, distinct spot patterns were obtained in case of the unidentified particles demonstrating their crystalline nature. Therefore, the presented ED images confirm that the fractal- and superaggregates have amorphous turbostratic structure with randomly oriented graphitic domains, while the other type particles (Fig. 24 a, b, c) have specific crystalline structures. (Fig. 24 d, e, f).

Offline investigations confirmed that soot fractal aggregates present in engine exhaust fuelled with the diesel and biodiesel have graphitic or turbostratic molecule structure and dominantly fall into the submicron size domain. Besides that, fractal super aggregates with extended dimensions and complexity could also be identified regardless of the applied fuel. Moreover, other types of particulates were also recognised having crystallite molecule structure and unknown thermal stability. 

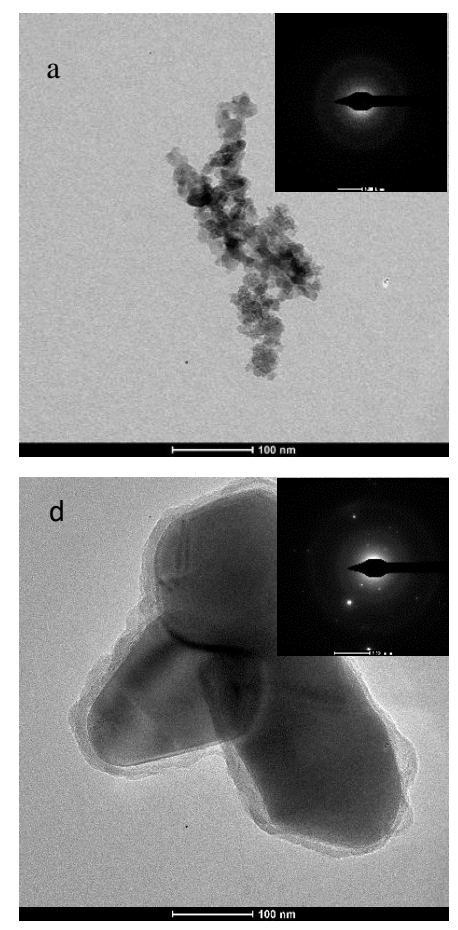

Figure 23. TEM ( $a, b, d, e, f), \operatorname{HRTEM}(c)$ and linked ED (inset) images illustrating the different kinds of

particles identified in the exhaust in case of pure diesel. Scale values are 100, 500, 10, 100, 50, $50 \mathrm{~nm}$, respectively.
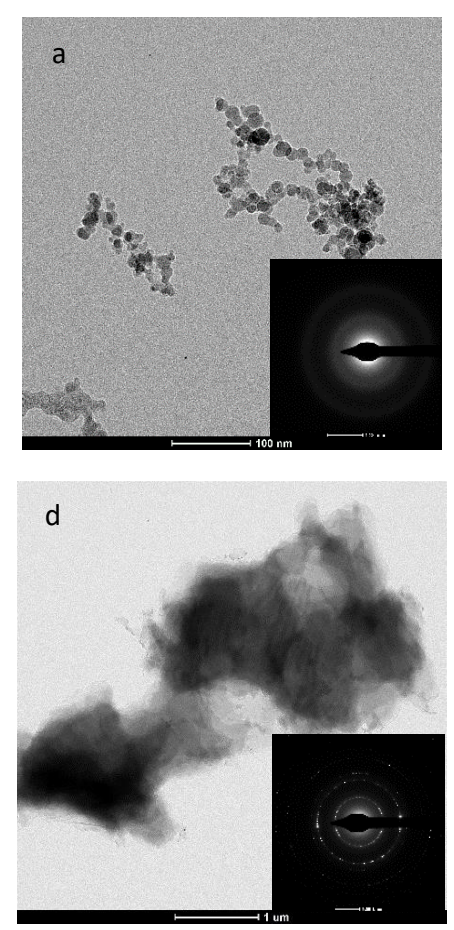
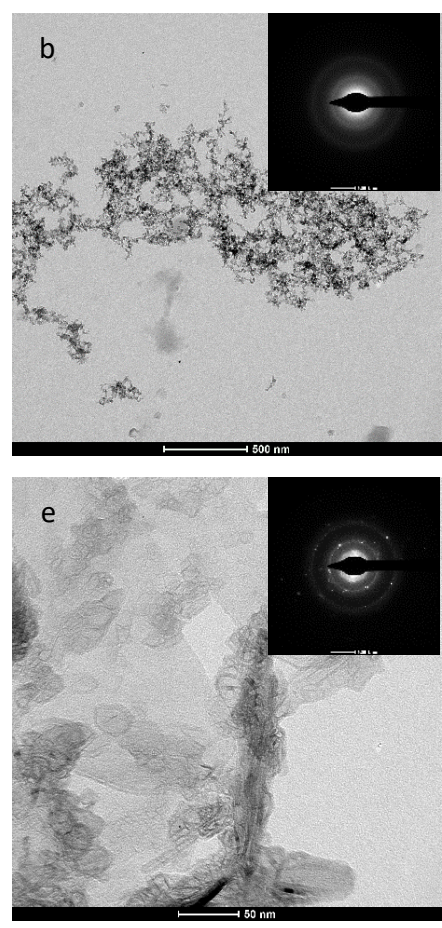
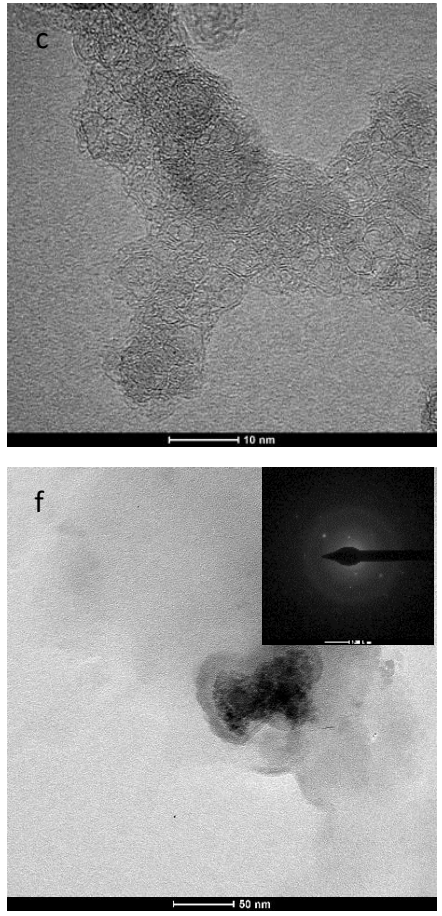
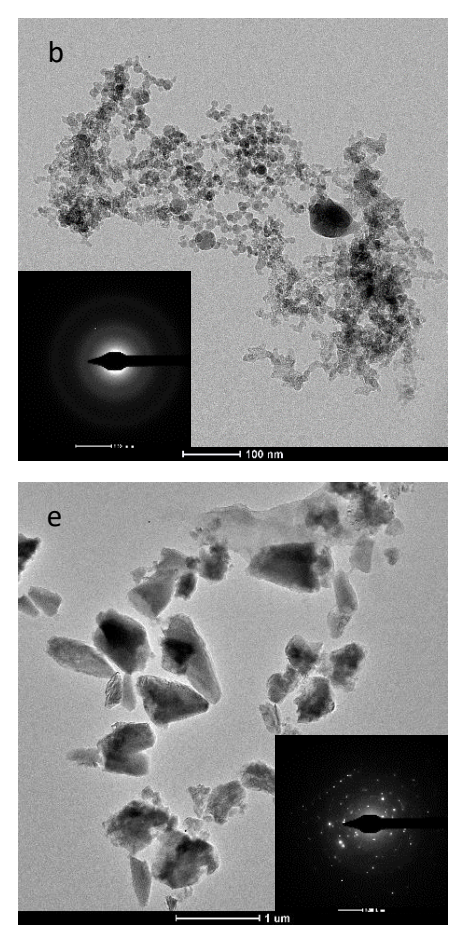
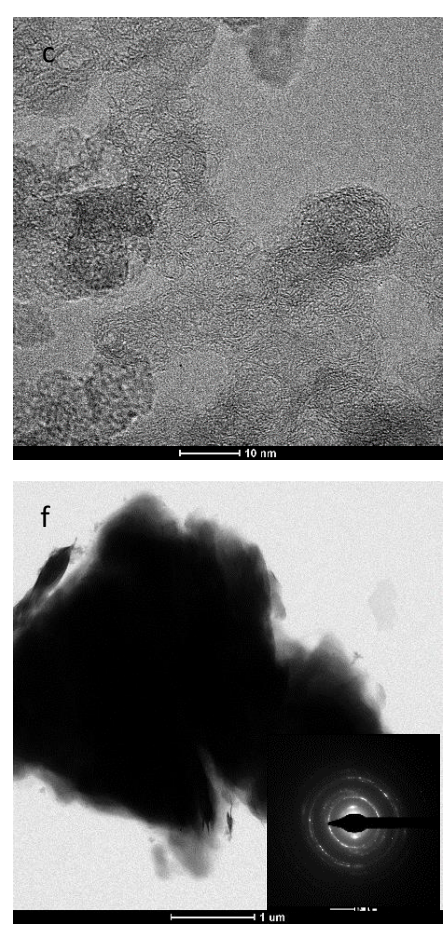

Figure 24. TEM ( $a, b, d, e, f), \operatorname{HRTEM}(c)$ and linked ED (inset) images illustrating the different kinds of particles identified in the exhaust in case of biodiesel blends. Scale values are 100, 100, $10 \mathrm{~nm}$, and 1, 1, 1, $\mu \mathrm{m}$, respectively. 


\section{Related thesis statements}

T2. I characterized particle emission from a heavy-duty diesel engine fuelled with blends of commercial diesel and biofuel (fatty acid methyl ester, FAME). The four investigated fuel blends were pure diesel (B0), 25\% FAME (B25), 75\% FAME (B75) and pure FAME (B100). I investigated diesel emission at three selected standard engine operating conditions (from idle mode to high engine load). The results of my measurements verified that diesel emitted particulate matter has lognormal size distribution in the accumulation mode (CMD of circa 100 $\mathrm{nm}$ ) among all measurement conditions. Emitted number and volume concentration was found to decrease in the function of engine load. Blending rate of FAME did not linearly affect emitted number and volume concentration. I measured the smallest emitted concentration in case of B75 regarding all operating conditions. This finding shows that developing new composition fuels (e.g. with higher biofuel content) could help further reduce particulate emission and fulfil tightening emission standards.

T3. I investigated the thermal evolution of diesel emitted particulate matter by posterior temperature treatment of the diesel exhaust at three temperatures using an in-house developed low-flow thermodenuder $\left(50^{\circ} \mathrm{C}, 120^{\circ} \mathrm{C}\right.$ and $\left.250^{\circ} \mathrm{C}\right)$. During the first temperature transition (50$120^{\circ} \mathrm{C}$ ), I observed a significant decrease in number and volume concentrations while no remarkable shift of the peak position of the size distribution curves. I proved that this is due to the evaporation of droplets formed by homogenous condensation and volatile matter previously adsorbed on the surface of soot particles as well as the pyrolysis of non-soot constituents in the exhaust. During the second temperature transition $\left(120-250^{\circ} \mathrm{C}\right)$, I observed further decrease in total volume concentration and structural changes in size distribution regarding all engine conditions and fuel types. In idle mode, total number concentrations did not show significant further decrease in case of all fuel types. Curiously, at higher engine loads, as opposed to pure fuels (B0 and B100), total number concentration increased during the second temperature transition in case of fuel blends (B25 and B75). I demonstrated that this phenomenon can be explained by the fragmentation of aggregates governed by thermal energy. 


\subsection{CORRELATIONS BETWEEN THE PHYSICAL, CHEMICAL AND TOXICOLOGICAL PROPERTIES OF ATMOSPHERIC CARBONACEOUS PARTICULATE MATTER}

The toxicological potential of atmospheric CPM is most generally determined by offline methodologies. Accordingly, they can provide information regarding air quality only with considerable time lag. As samples are most commonly collected with 24-hour time resolution, the diurnal variation of CPM toxicity and the relative contribution of emitting sources can remain vague in data interpretation (Cerna et al., 2000; Buschini et al., 2001; Kawanaka et al., 2004; de Kok et al., 2006, Roig et al., 2013). Decreasing the integration time of toxicity tests and uncovering the relationship between the physical and chemical properties, the relative contribution of emitting sources and the toxicological potential of atmospheric CPM could help developing more efficient urban air pollution strategies (de Kok et al., 2006).

Optically active organic carbonaceous aerosol constituents like $\mathrm{BrC}$ and HULIS were found to have severe toxicological impact (Donaldson et al., 1996; Donaldson et al., 2002; Li et al., 2003, 2009; Verma et al., 2009; Verma et al., 2012). Recently, significant correlation has been found between the toxicological potential and the concentration of carbonaceous constituents of diesel exhaust like TC and PAH compounds (Kováts et al., 2013; Kováts et al., 2012; Kováts et al., 2016). Although diesel emitted CPM is known to be ecotoxic (Lin and Chao, 2002; Papadimitriou et al., 2008; Vouitsis et al., 2009), biomass burning emission has recently been found to have an even higher ecotoxicological potential (Túróczi et al., 2012). Many recent studies have demonstrated that optically active CPM originating from various sources ( $\mathrm{BC}$ and $\mathrm{BrC}$ ) can be selectively identified based on their spectral response (Favez et al., 2009; Ajtai et al., 2011; Utry et al., 2014; Ajtai et al., 2015). Based on these, determining the correlation between offline studied chemical and toxicological properties and online measured optical characteristics of CPM could be another major step towards real-time air quality assessment.

In this chapter, I present the results of a field measurement campaign focusing on defining the relationship between the online and offline measured CPM parameters. I investigated the diurnal variation of the most relevant parameters describing urban CPM including real-time measured optical response and offline determined chemical and toxicological features. Based on their diurnal behaviour, I was aiming to demonstrate correlation between the measured parameters. Finally, I studied the possibility of first-screening the toxicological potential of optically active atmospheric CPM based on its real-time measured optical absorption features. 


\subsubsection{MEASUREMENT SITE}

The measurements were carried out during the winter of 2015 at two sites. Site 1 was a disused depot on the outskirts of the city of Szeged, Hungary $\left(46,284118^{\circ} \mathrm{N}, 20,170071^{\circ} \mathrm{E}\right)$. The campaign took place between 2015.01.07-2015.01.30. Site 2 was the observatory of the Hungarian Meteorological Service, in Budapest, the capital of Hungary $\left(47,430009^{\circ} \mathrm{N}\right.$, $\left.19,181225^{\circ} \mathrm{E}\right)$. The measurements were carried out between 2015.02.09-2015.02.28. Both sites are located in suburban areas. We have previously shown that in Szeged, under wintry conditions, the two dominant sources of CPM are traffic and biomass burning (Utry et al., 2014; Ajtai et al., 2015). It is important to point out that compared to Szeged, industrial activity is more dominant in Budapest. There are several industrial areas in surroundings Site 2 because of which, traffic and biomass burning are presumably not exclusive sources of CPM (Budapest környezeti állapotértékelése, 2014.). The characteristic meteorological conditions of the two sites are summarized in Table 10.

Table 10. Characteristic meteorological conditions at the two measurement sites during the campaigns

\begin{tabular}{cccc}
\hline Site 1 & Average & Min & Max \\
\hline $\begin{array}{c}\text { Temperature } \\
\left({ }^{\circ} \mathbf{C}\right)\end{array}$ & $4.14 \pm 2.68$ & -1.83 & 10.29 \\
\hline RH (\%) & $81.05 \pm 11.92$ & 38.60 & 93.42 \\
\hline $\begin{array}{c}\text { Wind speed } \\
(\mathbf{m} / \mathbf{s})\end{array}$ & $1.15 \pm 0.84$ & 0 & 4.09 \\
\hline Site 2 & Average & Min & Max \\
\hline $\begin{array}{c}\text { Temperature } \\
\left({ }^{\circ} \mathbf{C}\right)\end{array}$ & $4.11 \pm 3.71$ & -5.14 & 11.77 \\
\hline RH $(\%)$ & $70.99 \pm 16.73$ & 20.53 & 92.67 \\
\hline $\begin{array}{c}\text { Wind speed } \\
(\mathbf{m} / \mathbf{s})\end{array}$ & $1.09 \pm 0.65$ & 0 & 4.53 \\
\hline
\end{tabular}




\subsubsection{INSTRUMENTATION AND SAMPLING}

\section{Online measurements}

Online measurements were carried out by our mobile aerosol laboratory (Filep et al., 2013; Utry et al., 2014; Ajtai et al., 2015). All applied instruments were connected to PM2.5 cut-off inlets during the campaign placed approximately 2 meters above the roof of the measurement platform. Optical absorption coefficient (OAC) was measured by our in-house

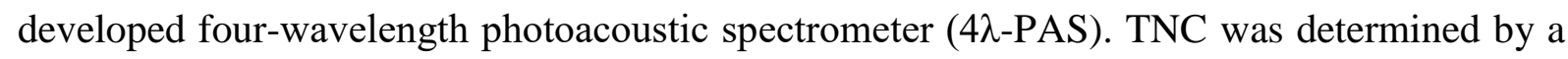
Portable Aerosol Spectrometer (Model 1.109, Grimm Aerosol Technik GmbH \& CO), measuring in the size range of 0.25-32 $\mu \mathrm{m}$. Mass concentration (PM2.5) was measured by a beta-ray attenuation spectrometer BAM-1020 (Met One Instruments Inc.). The concentration of gaseous compounds (CO, NOx, and BTEX (benzene, toluene, m,p-xylen, o-xylen and ethylbenzene)) was determined by a Syntech Spectras GC955 Gas Cromatograph (Synspec b.v.). The basic principle and theory of operation of the applied instruments are described in Section 4.1.

\section{Offline measurements}

Filter sampling was carried out with 6-hour time resolution by a Digitel DHA-80 (Digitel Elektronik $\mathrm{GmbH}$ ) high volume aerosol sampler equipped with a PM2.5 cut-off inlet. Filter sampling periods were 23:00-5:00, 5:00-11:00, 11:00-17:00 and 17:00-23:00. Aerosol samples were collected on pre-treated Whatman QM-A Quartz Microfiber Filters (diameter of $150 \mathrm{~mm}$ ) (GE Healthcare Life Sciences). Quartz filters were ignited at $680^{\circ} \mathrm{C}$ for 8 hours. Following that they were stored in aluminum film previously cleaned with acetone. Filter samples were analysed offline for chemical composition (Organic carbon (OC), Elemental carbon (EC), Total carbon (TC), Levoglucosan (LG), PAH concentrations) and ecotoxicity (EC50). Applied Offline methodologies are described in detail in Section 4.2. 


\subsubsection{DIURNAL VARIATION OF THE MEASURED PARAMETERS}

Statistical summary of the measured parameters with respect to sampling periods regarding Site 1 and Site 2 is found in Table $11 \mathrm{a}, \mathrm{b}$ and $\mathrm{c}$ and $12 \mathrm{a}$ and b. Collecting air samples with 6-hour time resolution enabled the investigation of the diurnal variation of not only the online but the offline measured aerosol parameters as well. Most measured physical-chemical parameters displayed distinctive diurnal variation. These included OAC, OC, EC, TC, LG, AAE, PM2.5, PAH and BTEX concentrations. Although, their behaviour differed in case of the two measurement sites. At Site 1, measured values had their minimum in the morning while their maximum in the evening. However, at Site 2 they had an additional local daytime minimum. Due to technical reasons OC, EC and TC Sunset data were not available at Site1.As opposed to that, the diurnal behaviour of $\mathrm{NO}_{\mathrm{x}}$ and $\mathrm{CO}_{2}$ showed a similar tendency in case of both sites. $\mathrm{NO}_{\mathrm{x}}$ was measured in the highest concentration during the day, while $\mathrm{CO}$ during the night. $\mathrm{CO}$ is often used as a tracer of household heating as it originates dominantly from smoldering (Fine et al., 2002; Puxbaum et al., 2007). The diurnal variation of CO can carry information about the relative contribution of household heating to total emission (Koppmann et al., 2005). The maximum of $\mathrm{NO}_{\mathrm{x}}$ concentration was measured detected in the morning and in the early evening when traffic activity is the highest. That is because it mostly originates from traffic emission (Sandradewi et al., 2008a, b; Favez et al., 2010; Utry et al., 2014). TNC showed no well-defined diurnal trend at either site. An exception is TNC, 0.25-0.5 $\mu \mathrm{m}$ measured at Site 2.

Based on the similarities of diurnal patterns, I investigated the correlation between the measured aerosol parameters. First, I present the methodology of correlation analysis. Following that, relationships between the measured physical-chemical parameters and OAC. After that correlations between the measured physical-chemical parameters and ecotoxicity (EC50) are discussed. Finally, I analyse correlation between OAC and ecotoxicity (EC50). 
Table 11 a. Statistical summary of measured raw data at the Site 1

\begin{tabular}{|c|c|c|c|c|c|c|c|c|}
\hline Site 1 & $23: 00-0$ & $0(\mathrm{~N}=21)$ & $05: 00-1$ & $0(\mathrm{~N}=21)$ & $11: 00-1$ & $0(\mathrm{~N}=20)$ & $17: 00-2$ & $0(\mathrm{~N}=20)$ \\
\hline Measured parameter & Average & $\begin{array}{l}\text { Standard } \\
\text { deviation }\end{array}$ & Average & $\begin{array}{l}\text { Standard } \\
\text { deviation }\end{array}$ & Average & $\begin{array}{l}\text { Standard } \\
\text { deviation }\end{array}$ & Average & $\begin{array}{r}\text { Standard } \\
\text { deviation }\end{array}$ \\
\hline OAC@1064nm [ $\left.\mathrm{Mm}^{-1}\right]$ & 1.95 & 0.74 & 3.55 & 1.40 & 4.06 & 1.52 & 4.54 & 2.10 \\
\hline $\begin{array}{c}\text { OAC@532nm } \\
{\left[\mathrm{Mm}^{-1}\right]}\end{array}$ & 6.64 & 2.46 & 11.15 & 4.57 & 12.33 & 5.32 & 14.60 & 6.94 \\
\hline $\begin{array}{c}\text { OAC@355nm } \\
{\left[\mathrm{Mm}^{-1}\right]}\end{array}$ & 22.56 & 10.17 & 34.63 & 17.31 & 37.58 & 16.98 & 47.62 & 23.72 \\
\hline AAE@1064-355nm & 2.16 & 0.16 & 1.99 & 0.18 & 1.96 & 0.16 & 2.08 & 0.10 \\
\hline AAE@532-355nm & 2.94 & 0.34 & 2.72 & 0.31 & 2.73 & 0.16 & 2.89 & 0.26 \\
\hline $\mathrm{OC}\left[\mu \mathrm{g} / \mathrm{m}^{3}\right]$ & n.a. & n.a. & n.a. & n.a. & n.a. & n.a. & n.a. & n.a. \\
\hline $\mathrm{EC}\left[\mu \mathrm{g} / \mathrm{m}^{3}\right]$ & n.a. & n.a. & n.a. & n.a. & n.a. & n.a. & n.a. & n.a. \\
\hline $\mathrm{TC}_{\text {Sunset }}\left[\mu \mathrm{g} / \mathrm{m}^{3}\right]$ & n.a. & n.a. & n.a. & n.a. & n.a. & n.a. & n.a. & n.a. \\
\hline $\mathrm{TC}_{\text {Zellwerg }}\left[\mu \mathrm{g} / \mathrm{m}^{3}\right]$ & 10.63 & 4.93 & 14.3 & 7.67 & 14.89 & 7.35 & 18.97 & 9.62 \\
\hline $\mathrm{LG}\left[\mu \mathrm{g} / \mathrm{m}^{3}\right]$ & 0.61 & 0.30 & 0.83 & 0.63 & 0.84 & 0.45 & 1.22 & 0.62 \\
\hline $\begin{array}{c}\text { TNC, } 0.25-0.5 \mu \mathrm{m} \\
{\left[10^{6} \text { counts } / 1\right]}\end{array}$ & 4.77 & 1.97 & 5.26 & 2.07 & 5.10 & 1.99 & 6.65 & 2.68 \\
\hline $\begin{array}{l}\text { TNC, } 0.5-1 \mu \mathrm{m} \\
{\left[10^{6} \text { counts } / 1\right]}\end{array}$ & 0.05 & 0.03 & 0.06 & 0.04 & 0.06 & 0.04 & 0.08 & 0.04 \\
\hline PM2.5 $\left[\mu \mathrm{g} / \mathrm{m}^{3}\right]$ & 31.81 & 15.08 & 28.27 & 11.8 & 26.96 & 11.73 & 31.19 & 13 \\
\hline
\end{tabular}


Table $11 \mathrm{~b}$. Statistical summary of measured raw data at the Site 1 (continued)

\begin{tabular}{|c|c|c|c|c|c|c|c|c|}
\hline \multirow{2}{*}{$\begin{array}{c}\text { Site } 1 \\
\text { Measured parameter }\end{array}$} & \multicolumn{2}{|c|}{$23: 00-05: 00(\mathrm{~N}=21)$} & \multicolumn{2}{|c|}{$05: 00-11: 00(\mathrm{~N}=21)$} & \multicolumn{2}{|c|}{$11: 00-17: 00(\mathrm{~N}=20)$} & \multicolumn{2}{|c|}{$17: 00-23: 00(\mathrm{~N}=20)$} \\
\hline & Average & $\begin{array}{l}\text { Standard } \\
\text { deviation }\end{array}$ & Average & $\begin{array}{l}\text { Standard } \\
\text { deviation }\end{array}$ & Average & $\begin{array}{l}\text { Standard } \\
\text { deviation }\end{array}$ & Average & $\begin{array}{l}\text { Standard } \\
\text { deviation }\end{array}$ \\
\hline $\begin{array}{c}\text { Ecotoxicity (1/EC50) } \\
{\left[\mu^{-1}\right]}\end{array}$ & 0.21 & 0.16 & 0.11 & 0.15 & 0.06 & 0.07 & 0.23 & 0.41 \\
\hline Phenantrene $\left[\mathrm{ng} / \mathrm{m}^{3}\right]$ & 1.55 & 1.06 & 1.97 & 1.60 & 2.51 & 1.70 & 3.22 & 3.85 \\
\hline Antracene $\left[\mathrm{ng} / \mathrm{m}^{3}\right]$ & 0.15 & 0.16 & 0.25 & 0.22 & 0.42 & 0.39 & 1.60 & 4.9 \\
\hline Fluorantene $\left[\mathrm{ng} / \mathrm{m}^{3}\right]$ & 2.64 & 1.58 & 4.42 & 2.21 & 7.15 & 5.10 & 7.23 & 4.83 \\
\hline Pyrene $\left[\mathrm{ng} / \mathrm{m}^{3}\right]$ & 4.58 & 2.79 & 8.30 & 4.95 & 12.41 & 10.24 & 12.09 & 7.30 \\
\hline $\begin{array}{c}\text { Benzo[a]antracene } \\
{\left[\mathrm{ng} / \mathrm{m}^{3}\right]}\end{array}$ & 1.42 & 0.84 & 3.72 & 2.96 & 4.61 & 2.87 & 7.30 & 5.44 \\
\hline Chrysene $\left[\mathrm{ng} / \mathrm{m}^{3}\right]$ & 2.67 & 2.01 & 5.07 & 3.79 & 5.79 & 3.58 & 8.78 & 6.26 \\
\hline $\begin{array}{c}\text { Benzo[b]fluoranthene } \\
{\left[\mathrm{ng} / \mathrm{m}^{3}\right]}\end{array}$ & 2.70 & 1.68 & 4.83 & 3.19 & 5.43 & 3.13 & 7.69 & 4.31 \\
\hline $\begin{array}{c}\text { Benzo[k]fluorantene } \\
{\left[\mathrm{ng} / \mathrm{m}^{3}\right]}\end{array}$ & 1.06 & 0.63 & 2.03 & 1.38 & 2.25 & 1.31 & 3.69 & 3.16 \\
\hline $\begin{array}{c}\text { Benzo[a] pyrene } \\
{\left[\mathrm{ng} / \mathrm{m}^{3}\right]}\end{array}$ & 1.82 & 1.11 & 4.17 & 3.11 & 4.71 & 2.98 & 6.95 & 4.47 \\
\hline
\end{tabular}


Table 11 c. Statistical summary of measured raw data at the Site 1 (continued)

\begin{tabular}{ccccccccc}
\hline $\begin{array}{c}\text { Dibezn[a,h] } \\
\text { antarcene [ng/m }]\end{array}$ & 0.31 & 0.23 & 0.67 & 0.66 & 0.71 & 0.55 & 1.65 & 3.35 \\
\hline $\begin{array}{c}\text { Benzo[g,h,i]perylene } \\
{\left[\mathrm{ng} / \mathrm{m}^{3}\right]}\end{array}$ & 1.39 & 1.10 & 2.67 & 2.09 & 2.92 & 2.02 & 4.46 & 4.39 \\
\hline $\begin{array}{c}\text { Indenopyrene } \\
{\left[\mathrm{ng} / \mathrm{m}^{3}\right]}\end{array}$ & 2.24 & 1.38 & 4.27 & 3.10 & 4.71 & 2.88 & 6.84 & 5 \\
\hline $\begin{array}{c}\text { Benzene [ppb] } \\
\text { Toluene [ppb] }\end{array}$ & 0.93 & 0.17 & 1 & 0.30 & 0.97 & 0.3 & 1.36 & 0.47 \\
\hline m,p-xylene [ppb] & 0.31 & 0.15 & 0.79 & 0.35 & 0.81 & 0.35 & 0.98 & 0.43 \\
\hline o-xylene [ppb] & 0.01 & 0.02 & 0.07 & 0.06 & 0.10 & 0.07 & 0.11 & 0.10 \\
\hline CO [ppm] & 657 & 168 & 627 & 207 & 577 & 142 & 620 & 143 \\
\hline NOx [ppb] & 31.62 & 13.41 & 31.58 & 15.01 & 24.47 & 13.65 & 31.52 & 25.55 \\
\hline
\end{tabular}


Table 12 a. Statistical summary of measured raw data at the Site 2

\begin{tabular}{|c|c|c|c|c|c|c|c|c|}
\hline Site 2 & \multicolumn{2}{|c|}{$23: 00-05: 00(\mathrm{~N}=30)$} & \multicolumn{2}{|c|}{$05: 00-11: 00(\mathrm{~N}=29)$} & \multicolumn{2}{|c|}{$11: 00-17: 00(\mathrm{~N}=29)$} & \multicolumn{2}{|c|}{$17: 00-23: 00(\mathrm{~N}=29)$} \\
\hline Measured parameter & Average & $\begin{array}{l}\text { Standard } \\
\text { deviation }\end{array}$ & Average & $\begin{array}{l}\text { Standard } \\
\text { deviation }\end{array}$ & Average & $\begin{array}{l}\text { Standard } \\
\text { deviation }\end{array}$ & Average & $\begin{array}{l}\text { Standard } \\
\text { deviation }\end{array}$ \\
\hline OAC@1064nm $\left[\mathrm{Mm}^{-1}\right]$ & 4.30 & 3.75 & 3.70 & 1.97 & 2.05 & 0.85 & 4.78 & 2.60 \\
\hline $\begin{array}{l}\text { OAC@532nm } \\
{\left[\mathrm{Mm}^{-1}\right]}\end{array}$ & 11.47 & 9.32 & 9.38 & 4.86 & 4.64 & 2.08 & 12.12 & 6.31 \\
\hline $\begin{array}{c}\text { OAC@355nm } \\
{\left[\mathrm{Mm}^{-1}\right]}\end{array}$ & 50.49 & 45.4 & 38.32 & 23.73 & 18.79 & 9.71 & 49.26 & 27.84 \\
\hline AAE@1064-355nm & 2.22 & 0.13 & 2.10 & 0.27 & 2.02 & 0.25 & 2.13 & 0.23 \\
\hline AAE@532-355nm & 3.83 & 0.47 & 3.47 & 0.47 & 3.45 & 0.71 & 3.63 & 0.65 \\
\hline $\mathrm{OC}\left[\mu \mathrm{g} / \mathrm{m}^{3}\right]$ & 16.96 & 12.06 & 13.35 & 7.04 & 7.82 & 2.8 & 19.35 & 10.39 \\
\hline $\mathrm{EC}\left[\mu \mathrm{g} / \mathrm{m}^{3}\right]$ & 1.96 & 1.4 & 1.97 & 0.91 & 1 & 0.40 & 2.73 & 1.22 \\
\hline $\mathrm{TC}_{\text {Sunset }}\left[\mu \mathrm{g} / \mathrm{m}^{3}\right]$ & 18.91 & 13.42 & 15.32 & 7.80 & 8.82 & 3.09 & 22.07 & 11.51 \\
\hline $\mathrm{TC}_{\text {Zellwerg }}\left[\mu \mathrm{g} / \mathrm{m}^{3}\right]$ & 17.99 & 12.33 & 14.80 & 7.54 & 9.01 & 3.9 & 20.29 & 9.53 \\
\hline $\mathrm{LG}\left[\mu \mathrm{g} / \mathrm{m}^{3}\right]$ & 1.26 & 1 & 0.79 & 0.49 & 0.35 & 0.16 & 1.40 & 0.85 \\
\hline $\begin{array}{c}\text { TNC, } 0.25-0.5 \mu \mathrm{m} \\
{\left[10^{6} \text { counts } / 1\right]}\end{array}$ & 0.93 & 0.59 & 0.80 & 0.41 & 0.49 & 0.25 & 0.89 & 0.53 \\
\hline $\begin{array}{l}\text { TNC, } 0.5-1 \mu \mathrm{m} \\
{\left[10^{6} \text { counts } / 1\right]}\end{array}$ & 0.01 & 0.01 & 0.01 & 0.01 & 0.01 & 0.01 & 0.02 & 0.01 \\
\hline PM2.5 $\left[\mu \mathrm{g} / \mathrm{m}^{3}\right]$ & 46.36 & 24.85 & 49.96 & 51.56 & 25.39 & 14.09 & 38.25 & 16.07 \\
\hline
\end{tabular}


Table 12 b. Statistical summary of measured raw data at the Site 2

\begin{tabular}{|c|c|c|c|c|c|c|c|c|}
\hline Site 2 & $23: 00-0$ & $0(\mathrm{~N}=30)$ & 05:00-1 & $0(\mathrm{~N}=29)$ & 11:00-1 & $0(\mathrm{~N}=29)$ & $17: 00-2$ & $0(\mathrm{~N}=29)$ \\
\hline Measured parameter & Average & $\begin{array}{l}\text { Standard } \\
\text { deviation }\end{array}$ & Average & $\begin{array}{l}\text { Standard } \\
\text { deviation }\end{array}$ & Average & $\begin{array}{r}\text { Standard } \\
\text { deviation }\end{array}$ & Average & $\begin{array}{l}\text { Standard } \\
\text { deviation }\end{array}$ \\
\hline $\begin{array}{c}\text { Ecotoxicity (1/EC50) } \\
{\left[\mu \mathrm{g}^{-1}\right]}\end{array}$ & 0.13 & 0.09 & 0.06 & 0.07 & 0.02 & 0.04 & 0.15 & 0.13 \\
\hline Phenantrene $\left[\mathrm{ng} / \mathrm{m}^{3}\right]$ & 4.41 & 3.81 & 3.24 & 1.57 & 1.61 & 0.73 & 4.87 & 3.24 \\
\hline Antracene $\left[\mathrm{ng} / \mathrm{m}^{3}\right]$ & 0.29 & 0.27 & 0.25 & 0.18 & 0.08 & 0.06 & 0.37 & 0.37 \\
\hline Fluorantene $\left[\mathrm{ng} / \mathrm{m}^{3}\right]$ & 7.42 & 7.31 & 5.91 & 3.68 & 2.78 & 1.23 & 10.18 & 8.07 \\
\hline Pyrene $\left[\mathrm{ng} / \mathrm{m}^{3}\right]$ & 19.25 & 21.18 & 12.33 & 8.61 & 4.85 & 2.51 & 28.6 & 24.12 \\
\hline $\begin{array}{c}\text { Benzo[a]antracene } \\
{\left[\mathrm{ng} / \mathrm{m}^{3}\right]}\end{array}$ & 6.13 & 7.98 & 3.46 & 2.44 & 0.84 & 0.58 & 10 & 8.40 \\
\hline Chrysene $\left[\mathrm{ng} / \mathrm{m}^{3}\right]$ & 6.89 & 7.44 & 4.59 & 3.29 & 1.28 & 0.67 & 10.11 & 8.33 \\
\hline $\begin{array}{c}\text { Benzo[b]fluoranthene } \\
{\left[\mathrm{ng} / \mathrm{m}^{3}\right]}\end{array}$ & 6.29 & 5.72 & 4.38 & 2.45 & 1.5 & 0.77 & 8.52 & 6.01 \\
\hline $\begin{array}{c}\text { Benzo[k]fluorantene } \\
{\left[\mathrm{ng} / \mathrm{m}^{3}\right]}\end{array}$ & 2.89 & 2.76 & 1.96 & 1.10 & 0.59 & 0.31 & 3.99 & 2.78 \\
\hline $\begin{array}{c}\text { Benzo[a] pyrene } \\
{\left[\mathrm{ng} / \mathrm{m}^{3}\right]}\end{array}$ & 6.78 & 7.48 & 4.05 & 2.31 & 1.09 & 0.67 & 9.81 & 7.35 \\
\hline $\begin{array}{c}\text { Dibezn }[\mathrm{a}, \mathrm{h}] \\
\text { antarcene }\left[\mathrm{ng} / \mathrm{m}^{3}\right]\end{array}$ & 0.60 & 0.55 & 0.41 & 0.31 & 0.12 & 0.09 & 0.84 & 0.88 \\
\hline $\begin{array}{c}\text { Benzo[g,h,i]perylene } \\
{\left[\mathrm{ng} / \mathrm{m}^{3}\right]}\end{array}$ & 2.28 & 2.28 & 1.78 & 1.27 & 0.45 & 0.37 & 3.32 & 2.97 \\
\hline $\begin{array}{c}\text { Indenopyrene } \\
{\left[\mathrm{ng} / \mathrm{m}^{3}\right]}\end{array}$ & 5.16 & 4.79 & 3.67 & 2.03 & 1.21 & 0.65 & 7.16 & 5.08 \\
\hline Benzene [ppb] & 1.09 & 0.69 & 0.89 & 0.48 & 0.48 & 0.21 & 1.08 & 0.49 \\
\hline Toluene [ppb] & 1.3 & 1.67 & 1.14 & 1.29 & 0.39 & 0.21 & 1.06 & 0.59 \\
\hline m,p-xylene [ppb] & 0.73 & 0.75 & 0.76 & 0.64 & 0.26 & 0.21 & 0.83 & 0.51 \\
\hline o-xylene [ppb] & 0.12 & 0.17 & 0.17 & 0.19 & 0.06 & 0.11 & 0.18 & 0.18 \\
\hline $\mathrm{CO}[\mathrm{ppm}]$ & 787 & 350 & 697 & 245 & 474 & 104 & 738 & 185 \\
\hline NOx [ppb] & 70.86 & 62.85 & 82.99 & 59.1 & 29.79 & 15.5 & 75.82 & 38.12 \\
\hline
\end{tabular}




\subsubsection{CORRELATION BETWEEN THE MEASURED PARAMETERS}

\section{Correlation analysis}

The interdependence between the measured parameters was quantified by correlation analysis. Pearson correlation coefficients $(r)$ were determined by MATLAB syntax 'corrcoef'. $r$ measures the linear association between two variables. Only correlations with a significance level ( $p$-value) exceeding 0.05 were considered. Determined $r$ values are listed in Table 14. and 15. $r$ values were classified into correlation strengths based on Table 13. (Rogers and Nicewander, 1988).

Table 13. Classification of $r$ values

\begin{tabular}{cc}
\hline $\boldsymbol{r}$ value range & strength of correlation \\
\hline$-1<r<-0.8$ & negative very strong correlation \\
\hline$-0.8<r<-0.6$ & negative strong correlation \\
\hline$-0.6<r<-0.4$ & negative moderate correlation \\
\hline$-0.4<r<-0.2$ & negative weak correlation \\
\hline$-0.2<r<0.2$ & negligible or no correlation \\
\hline $0.2<r<0.4$ & positive weak correlation \\
\hline $0.4<r<0.6$ & positive moderate correlation \\
\hline $0.6<r<0.8$ & positive strong correlation \\
\hline $0.8<r<1$ & positive very strong correlation
\end{tabular}

Correlations between OACs and the measured CPM related physical and chemical parameters

OACs measured at 3 operating wavelengths of the $4 \lambda$-PAS displayed strong positive correlation with carbon and levoglucosan concentrations determined by the Sunset Semi-

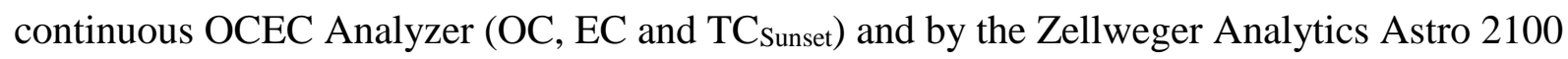
TOC Analyzer ( $\mathrm{TC}_{\text {Zellwerg }}$ and LG). That agrees with previous findings regarding the fact that CPM with considerable optical absorption is a dominant fraction of urban PM (Shiraiwa et al., 2008; Bond et al., 2013). It is interesting to point out that $r$ values did not show wavelength dependence at Site 2 whereas they did at Site1 (the strength of the correlation increased towards shorter wavelengths). TC determined by two different methods ( $\mathrm{TC}_{\text {Sunset }}$ and $\mathrm{TC}_{\text {Zellwerg}}$ ) very strongly correlated with each other ( $r=0.938$ and $r=0.967$ at Site 1 and 2, respectively). LG is a commonly used tracer of biomass burning and household heating under urban wintry measurement conditions (Fine et al., 2012; Puxbaum et al., 2007). Per that, the very strong 
correlation between LG and OC can indicate that household heating could make a dominant contribution to ambient $\mathrm{OC}$ at both sites ( $r=0.835$ and $r=0.953$ at Site 1 and 2 , respectively).

Moderate and strong correlations were found between OACs and TNC of particles with a mobility diameter of $0.25-0.5 \mu \mathrm{m}$. Correlations strengths weakened in case of particles with TNC between $0.5-1 \mu \mathrm{m}$. In addition, OACs showed only moderate correlation with PM2.5. These can be explained by the fact that the CMD of light absorbing ambient particles are most dominantly found in the $0.25-0.5 \mu \mathrm{m}$ size range (Bond et al., 2013).

Positive correlation was found between OACs measured by the $4 \lambda$-PAS and concentrations of PAH compounds determined from filter extracts. The concentrations of online measured gaseous ambient compounds (BTEX, $\mathrm{NO}_{\mathrm{x}}$ and $\mathrm{CO}$ ) also showed positive correlations with OACs.

Correlations between ecotoxicity (EC50) and the measured physical and chemical parameters

Correlations observed between ecotoxicity (EC50) and the measured physical and chemical parameters are discussed in this section. I was aiming to demonstrate and quantify the relationship between online measured optical absorption response and the offline assessed toxicological potential of CPM. It must be noted that ecotoxicity determined by the Vibrio Fischeri bioluminescence bioassay is not only sensitive to LAC, but also to the presence of transition and heavy metals in filter collected air samples (Roig et al., 2013). Although it was not a dedicated goal of this study, considering the ecotoxicological impact of heavy and transition metals could further increase the relevancy of data interpretation.

Ecotoxicity (EC50) was found to correlate with parameters describing particulate and gaseous ambient components (Table $14 \mathrm{a}$ and b). At Site 1, EC50 showed positive moderate

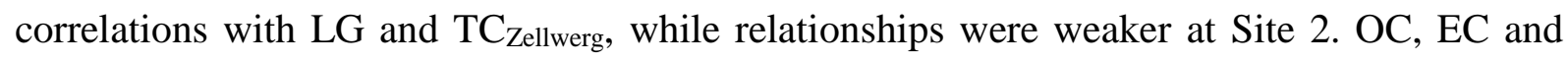
$\mathrm{TC}_{\text {Sunset }}$ data were only available at Site2, where weak correlations were determined between these parameters and ecotoxicity. Positive moderate correlation was found between EC50 and PM2.5 mass concentration at Site 1, however no significant correlation was observed at Site 2. EC50 moderately correlated with $\mathrm{NO}_{x}, \mathrm{CO}$ and PAH concentrations with $r$ values being slightly weaker at Site 2 compared to Site 1. No or only negligible correlations were found between BTEX concentrations and ecotoxicity at both sites. 
Table 14 a. Correlations between the measured parameters

\begin{tabular}{|c|c|c|c|c|c|c|c|c|c|}
\hline \multirow{2}{*}{\multicolumn{2}{|c|}{ Measured parameter }} & \multicolumn{2}{|c|}{ OAC@1064nm } & \multicolumn{2}{|c|}{ OAC@532nm } & \multicolumn{2}{|c|}{ OAC@355nm } & \multicolumn{2}{|c|}{$\begin{array}{l}\text { Ecotoxicity } \\
(1 / \text { EC50) }\end{array}$} \\
\hline & & Site 1 & Site 2 & Site 1 & Site 2 & Site 1 & Site 2 & Site 1 & Site 2 \\
\hline \multirow{3}{*}{$\begin{array}{l}\text { Sunset OCEC } \\
\text { analyzer }\end{array}$} & $\begin{array}{c}\text { Organic Carbon } \\
\text { (OC) }\end{array}$ & n.a. & 0.798 & n.a. & 0.807 & n.a. & 0.804 & n.a. & 0.245 \\
\hline & $\begin{array}{c}\text { Elemental } \\
\text { Carbon (EC) }\end{array}$ & n.a. & 0.852 & n.a. & 0.866 & n.a. & 0.793 & n.a. & 0.267 \\
\hline & $\begin{array}{l}\text { Total Carbon } \\
\left.\text { (TC } C_{\text {Sunset }}\right)\end{array}$ & n.a. & 0.810 & n.a. & 0.818 & n.a. & 0.808 & n.a. & 0.250 \\
\hline \multirow{2}{*}{ Filter extraction } & $\begin{array}{l}\text { Total Carbon } \\
\text { (TC } \text { Tellwerg })\end{array}$ & 0.784 & 0.814 & 0.899 & 0.823 & 0.926 & 0.809 & 0.485 & 0.254 \\
\hline & Levoglucosan & 0.759 & 0.780 & 0.825 & 0.809 & 0.869 & 0.785 & 0.502 & 0.266 \\
\hline \multirow{2}{*}{$\begin{array}{l}\text { Total number } \\
\text { concentration }\end{array}$} & $0.25-0.5 \mu \mathrm{m}$ & 0.734 & 0.567 & 0.815 & 0.747 & 0.824 & 0.760 & 0.487 & 0.290 \\
\hline & $0.5-1 \mu \mathrm{m}$ & 0.449 & 0.475 & 0.406 & 0.574 & 0.371 & 0.579 & 0.268 & 0.228 \\
\hline $\begin{array}{c}\text { Mass } \\
\text { concentration }\end{array}$ & PM2.5 & 0.544 & 0.449 & 0.681 & 0.434 & 0.653 & 0.420 & 0,561 & - \\
\hline
\end{tabular}


Table 14 b. Correlations between the measured parameters (continued)

\begin{tabular}{|c|c|c|c|c|c|c|c|c|c|}
\hline \multirow{2}{*}{\multicolumn{2}{|c|}{ Measured parameters }} & \multicolumn{2}{|c|}{ OAC@1064nm } & \multicolumn{2}{|c|}{ OAC@532nm } & \multicolumn{2}{|c|}{ OAC@355nm } & \multicolumn{2}{|c|}{$\begin{array}{c}\text { Ecotoxicity } \\
(1 / \mathrm{EC} 50) \\
\end{array}$} \\
\hline & & Site 1 & Site 2 & Site 1 & Site 2 & Site 1 & Site 2 & Site 1 & Site 2 \\
\hline & $\mathrm{NO}_{\mathrm{X}}$ & 0.747 & 0.836 & 0.748 & 0.837 & 0.680 & 0.757 & 0.316 & 0.189 \\
\hline & $\mathrm{CO}$ & 0.754 & 0.788 & 0.807 & 0.827 & 0.833 & 0.792 & 0.393 & 0.300 \\
\hline \multirow{12}{*}{ PAH } & Phenantrene $\left[\mathrm{ng} / \mathrm{m}^{3}\right]$ & 0.479 & 0.825 & 0.653 & 0.811 & 0.639 & 0.798 & 0.276 & 0.193 \\
\hline & Antracene $\left[\mathrm{ng} / \mathrm{m}^{3}\right]$ & 0.382 & 0.607 & 0.514 & 0.597 & 0.504 & 0.537 & & 0.194 \\
\hline & Fluorantene $\left[\mathrm{ng} / \mathrm{m}^{3}\right]$ & 0.57 & 0.795 & 0.698 & 0.786 & 0.669 & 0.728 & 0.318 & 0.186 \\
\hline & Pyrene $\left[\mathrm{ng} / \mathrm{m}^{3}\right]$ & 0.446 & 0.783 & 0.464 & 0.777 & 0.454 & 0.729 & 0.290 & 0.195 \\
\hline & $\begin{array}{c}\text { Benzo[a]antracene } \\
{\left[\mathrm{ng} / \mathrm{m}^{3}\right]}\end{array}$ & 0.687 & 0.775 & 0.744 & 0.777 & 0.744 & 0.725 & 0.364 & 0.212 \\
\hline & Chrysene $\left[\mathrm{ng} / \mathrm{m}^{3}\right]$ & 0.659 & 0.755 & 0.762 & 0.751 & 0.765 & 0.734 & 0.390 & 0.222 \\
\hline & $\begin{array}{c}\text { Benzo[b]fluoranthene } \\
{\left[\mathrm{ng} / \mathrm{m}^{3}\right]}\end{array}$ & 0.731 & 0.771 & 0.829 & 0.778 & 0.835 & 0.744 & 0.425 & 0.246 \\
\hline & $\begin{array}{c}\text { Benzo[k]fluorantene } \\
{\left[\mathrm{ng} / \mathrm{m}^{3}\right]} \\
\end{array}$ & 0.691 & 0.799 & 0.804 & 0.808 & 0.805 & 0.775 & 0.346 & 0.247 \\
\hline & Benzo[a] pyrene $\left[\mathrm{ng} / \mathrm{m}^{3}\right]$ & 0.736 & 0.807 & 0.804 & 0.811 & 0.808 & 0.774 & 0.401 & 0.232 \\
\hline & $\begin{array}{c}\text { Dibezn[a,h] antarcene } \\
{\left[\mathrm{ng} / \mathrm{m}^{3}\right]} \\
\end{array}$ & 0.477 & 0.543 & 0.616 & 0.548 & 0.605 & 0.515 & - & 0.200 \\
\hline & $\begin{array}{c}\text { Benzo[g,h,i]perylene } \\
{\left[\mathrm{ng} / \mathrm{m}^{3}\right]} \\
\end{array}$ & 0.646 & 0.676 & 0.792 & 0.680 & 0.785 & 0.674 & 0.318 & 0.222 \\
\hline & Indenopyrene $\left[\mathrm{ng} / \mathrm{m}^{3}\right]$ & 0.709 & 0.773 & 0.835 & 0.779 & 0.832 & 0.748 & 0.371 & 0.242 \\
\hline \multirow{4}{*}{ BTEX } & Benzene & 0.715 & 0.794 & 0.796 & 0.818 & 0.777 & 0.800 & - & - \\
\hline & Toluene & 0.672 & 0.651 & 0.718 & 0.658 & 0.686 & 0.643 & - & - \\
\hline & m.p-xylene & 0.571 & 0.788 & 0.588 & 0.796 & 0.530 & 0.714 & - & - \\
\hline & o-xylene & 0.623 & 0.644 & 0.651 & 0.673 & 0.557 & 0.548 & - & - \\
\hline
\end{tabular}


Correlations between the optical absorption response (OAC and AAE) and the ecotoxicity of $\underline{C P M}$

Several previous studies proved that optically active CPM has significant ecotoxicological potential (Turóczi et al., 2012; Ács et al., 2013). The fact that OACs and ecotoxicity both correlated with the concentration of carbonaceous constituents of CPM also suggests light absorbing carbonaceous particulate matter (LAC) is ecotoxic. To support this statement, correlation between OACs and EC50 was investigated.

Positive weak to moderate correlations were found between OACs and ecotoxicity at Site1 with a clear wavelength dependence (Table 15.). At Site2, $r$ values are lower, and no wavelength dependence could be observed (Table 15.). One reason for the difference between the two sites could be due to the presence of a third CPM emitting source besides household heating and traffic (Budapest környezeti állapotértékelése, 2014; Utry et al., 2014; Ajtai et al., 2015). It is also possible that correlations are less clear as ecotoxicity is also affected by other ambient constituents like metals that do not have any contribution to light absorption by aerosol. The wavelength dependence of $r$ values at Site 1 implies that EC50 could also correlate with the wavelength dependence of optical absorption (described by AAE).

Table 15. Correlation between OACs and toxicity

\begin{tabular}{lcc}
\hline & \multicolumn{2}{c}{$\begin{array}{c}\text { Ecotoxicity } \\
(1 / \text { EC50) }\end{array}$} \\
\cline { 2 - 3 } & Site 1 & Site 2 \\
\hline OAC@ 1064nm & 0.335 & 0.230 \\
\hline OAC@ 532nm & 0.384 & 0.275 \\
\hline OAC@ 355nm & 0.424 & 0.220
\end{tabular}

Weak and moderate correlation was found between ecotoxicity and AAEs at Site1. The relationship is stronger between EC50 and AAE determined on a narrower wavelength range (AAE@532-355nm) (Table 16.). As expected from the weaker $r$ values determined between OACs and EC50, no significant correlations were found between ecotoxicity and AAEs at Site2. Ecotoxicity weakly and moderately correlated with LG/TC Zellwerg ratio at Site1 and 2, respectively. LG being a tracer of biomass burning (Fine et al., 2012; Puxbaum et al., 2007), 
LG/ TCZellwerg ratio can carry information on the relative strength of household heating compared to other sources of CPM (Utry et al., 2014). Previous studies have recently shown that among urban wintry conditions, the most dominant sources of CPM are traffic and household heating (Utry et al., 2014; Ajtai et al., 2015). Turóczi et al., 2012 found that CPM emission from household heating had higher ecotoxicological potential than that of traffic. The positive correlation between $\mathrm{LG} / \mathrm{TC}$ Zellwerg verifies this finding.

Table 16. Correlations between ecotoxicity, AAE and LG/TC

\begin{tabular}{ccc}
\hline & \multicolumn{2}{c}{$\begin{array}{c}\text { Ecotoxicity } \\
(1 / \text { EC50) }\end{array}$} \\
\cline { 2 - 3 } & Site 1 & Site 2 \\
\hline AAE@ 1064- \\
355nm & 0.309 & - \\
\hline AAE@ 532- & & \\
355nm & 0.448 & - \\
\hline LG/TCZellwerg & 0.486 & 0.326 \\
\hline
\end{tabular}

Several papers, including earlier publications of the MTA-SZTE Research Group on Photoacoustic Spectroscopy, showed that the diurnal variation of AAE can carry information regarding the relative strength of the most dominant sources of LAC (traffic and household heating), thus the chemical composition of CPM (Sandradewi et al., 2008a, b; Favez et al., 2009; Ajtai et al., 2015). Higher AAE during the night indicates the extensive presence of more organic carbonaceous particles, thus the dominance of household heating. Lower AAE during the day including rush hours indicates the dominance of CPM emitted by traffic activity. Figure 25. shows that AAE@532-355nm showed a similar trend during this campaign as well. It is important to point out that error bars related to the displayed average values do not indicate the uncertainty of the measured data but the inherent feature of presentation the diurnal variation of data during field measurements. In such a case averaging is carried out with respect to corresponding time periods and not the cohesive ambient factors such as the meteorological or photochemical parameters (Sandradewi et al., 2008a, b; Favez et al., 2009).

Due to the limited number of measured data corresponding to the same time interval and mostly to similar meteorological conditions, statistically relevant conclusions cannot be drawn from this database. Fig. 25. only demonstrates the fact that based on the similar diurnal trend 
of AAE and ecotoxicity, AAE could be applied as not only a source selective parameter, but an online indicator for preliminary assessing the toxicological potential of CPM. Although the Vibrio Fischeri bioluminescence bioassay only gives information about the ecotoxicological impact of CPM, it has recently been shown that it can be used to describe the spatial pattern of air pollution (Aammi et al., 2017).

This measurement campaign was the first to investigate the diurnal variation of the toxicological potential of urban particulate matter. Also, this study was the first to determine correlation between the online measured optical absorption (AAE and OAC) and the offline determined ecotoxicological effect of CPM. Numerous earlier studies showed that optically active fraction of CPM has remarkable impact on human health and earthly ecosystems (Donaldson et al., 1996; Donaldson et al., 2002; Li et al., 2003, 2009; Verma et al., 2009; Verma et al., 2012; Ács et al., 2013; Túroczi et al., 2012). Based on the found correlations, AAE is proposed to be a possible candidate for first-screening the toxicological potential of LAC. To verify this proposition, longer measurements campaigns must be carried out, where the found correlations can be studied in function of various meteorological, spatial factors and emitting sources. The ecotoxicological effect of heavy and transition metals also must be considered, so the concentrations of those should also be measured simultaneously.

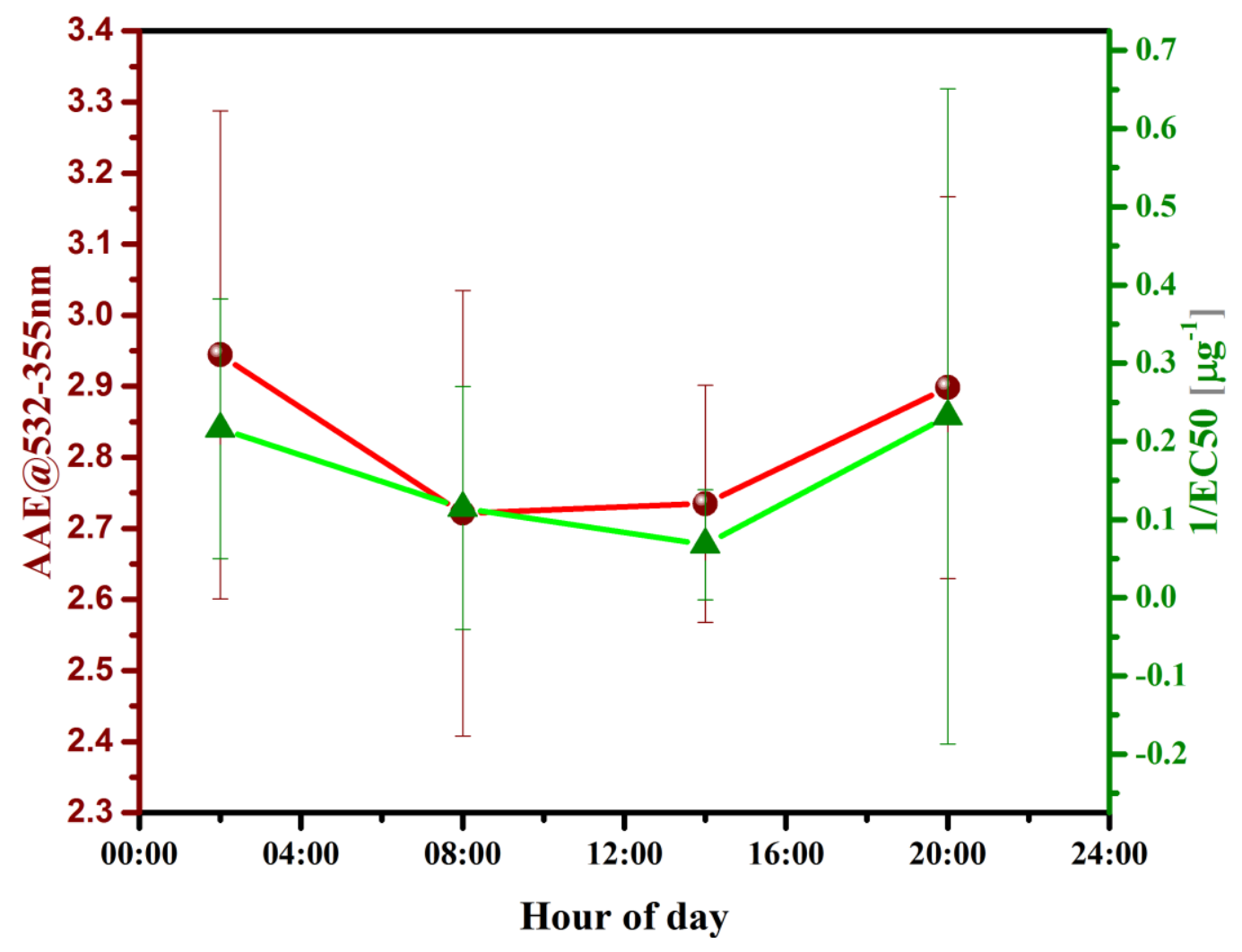

Figure 25. The diurnal variation of $A A E$ and ecotoxicity 


\section{$\underline{\text { Related thesis statement }}$}

T4. I investigated the diurnal variation and the correlations between the physical, chemical properties and the toxicological potential of atmospheric carbonaceous particulate matter (CPM) during a 2-month field measurement campaign carried out under urban wintry condition at two locations. Optical and microphysical features including optical absorption, light scattering, size distribution and mass concentration were measured using online state-of-the-art instrumentation. Filter samples were collected for offline chemical and toxicological analyses (concentration of PAH, BTEX compounds, total carbon (TC), organic carbon (OC), levoglucosan (LG) and ecotoxicity) with 6-hour time resolution. I found weak to moderate correlations between ecotoxicity and the optical, microphysical and chemical characteristics of CPM suggesting that CPM has remarkable ecotoxicological potential. I found moderate correlation between ecotoxicity determined by the Vibrio Fisheri bioluminescence bioassay and the wavelength dependence of optical absorption (AAE) determined by online aerosol phase photoacoustic measurements. I demonstrated that besides being a chemically and source selective parameter, AAE could also be a possible indicator for first screening the toxicological potential of CPM. 


\section{SUMMARY}

Atmospheric carbonaceous aerosol is a concurrent matter of concern in our time due to its impact on climate and human health. Its legal regulation is also a central issue of debates in the scientific community. Black Carbon is the second most significant anthropogenic air pollutant regarding its radiative forcing following $\mathrm{CO}_{2}$. Particulate matter is projected to be an important forcer of climate until the end of the $21^{\text {st }}$ century when it is to be outnumbered by greenhouse gases. The spectral response and the size distribution of atmospheric aerosol are key features to be investigated for better understanding both its climatic role and its impact on human health and earthly ecosystems.

The inherent characteristics of airborne carbonaceous particles primarily depend on the conditions of formation and the type of fuel. Their apparent features measured in immission are largely masked by atmospheric aging processes. Consequently, controlled laboratory generation and investigation of the complex parameter set describing CPM in the function of fuel type and the conditions of formation is highly relevant scientific goal of our time.

In urban areas, the most dominate sources of urban CPM during the winter are traffic and domestic heating. While strictening emission standards and adjunct technological solutions have the potential to give an answer to decreasing traffic-related emission, issues of domestic CPM emission are to be solved in the future. Several studies have assumed emission from domestic burning to have a higher toxicological potential than that of traffic. Future air pollution strategies should tackle the inherent toxicological risks of emitting sources regarding the regulation of PM. In order to do that major research should be focused on developing faster response time or even online methodologies for assessing the relative contribution of emitting sources and the impact of CPM on human health and ecosystems.

During my doctoral research I studied size distribution, morphology and microstructure of artificially generated model as well as real diesel emitted CPM. I investigated the impact of various burning conditions and fuel types on the characteristics parameters of emitted CPM. I also studied the correlations between the online measured optical absorption properties and the offline studied chemical and toxicological potential of urban CPM. I assessed the applicability of the AAE as a first-screening indicator of CPM toxicity. 


\section{New scientific results summarized in thesis statements}

T1. I investigated the size distribution, morphology and microstructure of CPM generated from a graphite target by laser ablation. This CPM generating setup ensures a unique possibility for evolving particles with various microphysical parameters and morphology. The tunable parameters of the setup are fluence of laser excitation, flow rate and composition of carrier gas in the ablation chamber. Each parameter can be independently controlled. Generating parameters can model temperature of ignition, physical aging and occurring atmospheric processes, respectively. I experimentally proved that generated carbonaceous particulate matter models real atmospheric soot well.

T2. I characterized particle emission from a heavy-duty diesel engine fuelled with blends of commercial diesel and biofuel (fatty acid methyl ester, FAME). The four investigated fuel blends were pure diesel (B0), 25\% FAME (B25), 75\% FAME (B75) and pure FAME (B100). I investigated diesel emission at three selected standard engine operating conditions (from idle mode to high engine load). The results of my measurements verified that diesel emitted particulate matter has lognormal size distribution in the accumulation mode (CMD of circa 100 $\mathrm{nm}$ ) among all measurement conditions. Emitted number and volume concentration was found to decrease in the function of engine load. Blending rate of FAME did not linearly affect emitted number and volume concentration. I measured the smallest emitted concentration in case of B75 regarding all operating conditions. This finding shows that developing new composition fuels (e.g. with higher biofuel content) could help further reduce particulate emission and fulfil tightening emission standards.

T3. I investigated the thermal evolution of diesel emitted particulate matter by posterior temperature treatment of the diesel exhaust at three temperatures using an in-house developed low-flow thermodenuder $\left(50^{\circ} \mathrm{C}, 120^{\circ} \mathrm{C}\right.$ and $\left.250^{\circ} \mathrm{C}\right)$. During the first temperature transition $(50$ $120^{\circ} \mathrm{C}$ ), I observed a significant decrease in number and volume concentrations while no remarkable shift of the peak position of the size distribution curves. I proved that this is due to the evaporation of droplets formed by homogenous condensation and volatile matter previously adsorbed on the surface of soot particles as well as the pyrolysis of non-soot constituents in the exhaust. During the second temperature transition $\left(120-250^{\circ} \mathrm{C}\right)$, I observed further decrease in total volume concentration and structural changes in size distribution regarding all engine conditions and fuel types. In idle mode, total number concentrations did not show significant further decrease in case of all fuel types. Curiously, at higher engine loads, as opposed to pure 
fuels (B0 and B100), total number concentration increased during the second temperature transition in case of fuel blends (B25 and B75). I demonstrated that this phenomenon can be explained by the fragmentation of aggregates governed by thermal energy.

T4. I investigated the diurnal variation and the correlations between the physical, chemical properties and the toxicological potential of atmospheric carbonaceous particulate matter (CPM) during a 2-month field measurement campaign carried out under urban wintry condition at two locations. Optical and microphysical features including optical absorption, light scattering, size distribution and mass concentration were measured using online state-of-the-art instrumentation. Filter samples were collected for offline chemical and toxicological analyses (concentration of PAH, BTEX compounds, total carbon (TC), organic carbon (OC), levoglucosan (LG) and ecotoxicity) with 6-hour time resolution. I found weak to moderate correlations between ecotoxicity and the optical, microphysical and chemical characteristics of CPM suggesting that CPM has remarkable ecotoxicological potential. I found moderate correlation between ecotoxicity determined by the Vibrio Fisheri bioluminescence bioassay and the wavelength dependence of optical absorption (AAE) determined by online aerosol phase photoacoustic measurements. I demonstrated that besides being a chemically and source selective parameter, AAE could also be a possible indicator for first screening the toxicological potential of CPM. 


\section{ÖSSZEFOGLALÓ}

A szálló por széntartalmú frakciója első sorban éghajlati és egészségügyi hatásai miatt számít napjaink egyik legjelentősebb környezeti kockázatának. Törvényi szabályozásának kérdésköre is izzó vitákat szít a tudományos közösségben. A legfrissebb tudományos kutatások alapján a légköri korom a második legnagyobb éghajlati kényszerrel rendelkező antropogén légszennyező a szén-dioxid után. Napjaink klimatikus előrejelzései szerint a szálló por éghajlatmódosító hatása egészen a 21. század végéig meghatározó lesz. Ezt követően a légkörben fokozatosan felhalmozódó üvegházhatású gázok szerepe lesz uralkodó. A légköri aeroszolok éghajlati, egészségügyi, valamint ökoszisztémára gyakorolt hatásaik pontos megértéséhez méreteloszlásuk és spektrális válaszuk vizsgálata kulcsfontosságú.

A légköri széntartlamú részecskék inherens jellemzői nagyban függnek a keletkezés körülményeitől, valamint a tüzelőanyag típusától. Vizsgálatukat nehezíti, hogy látszólagos tulajdonságaik légköri életidejük alatt, úgynevezett öregedési folyamatok során jelentősen megváltozhatnak. Ebből következik, hogy összetett jellemzőik kontrolállt, laboratórium körülmények közötti vizsgálata - a keletkezési körülmények és a tüzelőanyag típus függvényében - napjaink kiemelkedő fontosságú tudományos célkitüzése.

Téli városi környezetben, a szálló por széntartalmú frakciójának fö forrásai a közlekedés és a háztartási fütés. Míg az egyre szigorodó emissziós szabványok és jogszabályok ösztönözte technológiai fejlesztések hosszú távon megoldást jelenthetnek a közlekedéshez köthető kibocsátás okozta problémák megfékezésére, addig a háztartási szektor kibocsátását övező kérdések megválaszolása még jócskán várat magára. Számos tanulmány kimutatta, hogy a háztartási tüzelés során keletkező részecskék toxikusabbak lehetnek, mint a közlekedés során kibocsátottak. A jövőbeli levegőtisztaság-védelmi stratégiáknak a különböző kibocsátó forrásokhoz kapcsolódó egyedi toxikológiai kockázatokat is figyelembe kell majd venniük a szálló por szabályozás során. Ehhez elengedhetetlen, hogy jelentős kutatási erőforrásokat fordítsunk jelenleginél gyorsabb válasz idejü, online mérési módszerek kifejlesztésére, melyek akár valós időben is képesek meghatározni a kibocsátó források relatív járulékát, valamint monitorozni a légköri széntartalmú aeroszol egészségügyi és ökoszisztémákra gyakorolt hatásait.

Doktori munkám során mesterségesen előállított, valamint dízel emittált széntartalmú aeroszol méreteloszlását, morfológiáját, valamint mikroszerkezetét vizsgáltam. Tanulmányoztam, hogy a különböző égési körülmények, valamint üzemanyag típusok milyen 
hatást gyakorolnak a keletkező részecskék tulajdonságaira. Továbbá terepi körülmények között vizsgáltam a városi széntartalmú aeroszol valós időben, aeroszol fázisban mért optikai abszorpciós sajátosságai és az offline módszerrel vizsgált kémiai tulajdonságai, valamint toxicitása között fennálló korrelációkat. Megvizsgáltam, hogy az optikai abszorpció hullámhosszfüggését jellemző abszorpciós Angström exponens (AAE) alkalmas lehet-e a széntartalmú aeroszol toxicitásának előzetes előre-jelzésére.

\section{Új tudományos eredmények}

T1. Meghatároztam nagy tisztaságú grafit céltárgyból lézeres abláció útján generált széntartalmú aeroszol méreteloszlását, morfológiáját, valamint mikroszerkezetét. A lézeres ablációs aeroszol generátor egyedi lehetőséget teremt a legkülönbözőbb mikrofizikai paraméterekkel és morfológiával rendelkező részecskék előállítására. A generátor állítható paraméterei a gerjesztés során a mintára jutó energiasürüség, valamint az ablációs kamrában áramló vivőgáz áramlási sebessége és összetétele. A generálási paraméterek, melyek az égési hőmérsékletet, a fizikai öregedést, valamint a fellépő légköri folyamatokat hivatottak modellezni, egymástól függetlenül állíthatók. Kísérleti úton bizonyítottam, hogy a generált széntartalmú aeroszol jól modellezi a valós légköri kormot.

T2. Dízellel és biodízellel (zsírsav-metilészter, FAME), valamint különböző arányú keverékeikkel tankolt nagy teljesítményü dízel motor kibocsátását karakterizáltam. A négy vizsgált üzemanyag keverék a következő volt: kereskedelmi forgalomban kapható „tiszta” dízel (B0), 25\% FAME (B25), 75\% FAME (B75) és 100\% FAME (B100). A kibocsátott kipufogógázt három - a vonatkozó szabványoknak is megfelelő - egyensúlyi motorponton vizsgáltam (alapjárat, közepes és magas terhelés). A mérési eredmények megerősítették, hogy dízelmotor által kibocsátott részecskék minden motorállapot esetén jellemzően lognormális eloszlással rendelkeznek az akkumulációs módus tartományban, melynek szám szerinti medián átmérője hozzávetőlegesen $100 \mathrm{~nm}$. A kibocsátott részecskék szám szerinti koncentrációja és térfogat minden üzemanyagkeverék esetén csökkenést mutatott a motorterhelés függvényében. A FAME bekeverési aránya nem lineárisan csökkenést hozott a kibocsátott mennyiségben. Minden motorterhelési ponton a B75 üzemanyag esetében volt a legkisebb kibocsátott koncentráció. Az eredmények azt mutatják, hogy új összetételü (pl.: magasabb biodízel tartalmú) üzemanyagok fejlesztése elősegítheti a dízel motorok részecske-kibocsátásának csökkentését, valamint azt, hogy a motorgyártók megfeleljenek az egyre szigorodó szabályozásoknak. 
T3. Egy saját fejlesztésű alacsony átáramlású termikus gőzleválasztó egység (thermodenuder) segítségével vizsgáltam dízel kipufogógázban található eltérő termális tulajdonságú komponensek koncentráció arányait három hömérsékleten $\left(50^{\circ} \mathrm{C}, 120^{\circ} \mathrm{C}\right.$ and $\left.250^{\circ} \mathrm{C}\right) . \mathrm{Az} 50^{\circ} \mathrm{C}$ hoz képest $120^{\circ} \mathrm{C}$-on jelentős szám- és térfogat-koncentráció csökkenést tapasztaltam, miközben a maximális koncentrációhoz tartozó részecskeméret nem változott számottevően. Igazoltam, hogy ez a jelenség a homogén kondenzáció során keletkezett folyadékcseppek, valamint a dízel korom részecskék felületén adszorbeálódott illékony komponensek elpárolgásának, továbbá a kipufogógázban található, koromtól különböző aeroszol részecskék pirolízisének tudható be. A második hőmérsékleti lépcső $\left(120^{\circ} \mathrm{C}-250^{\circ} \mathrm{C}\right)$ további térfogatkoncentráció csökkenést eredményezett. Emellett a méreteloszlás görbékben bekövetkező szerkezeti változásokat tapasztaltam minden motorterhelési pont, valamint üzemanyagkeverék esetén. Az összdarabszám-koncentráció alapjáraton egyik üzemanyagkeverék esetén sem mutatott jelentős további csökkenést. Érdekes módon, nagyobb motorterhelés mellett a "tiszta" üzemanyagokkal ellentétben (B0 és B100), a keverék esetében (B25 és B75) $250^{\circ} \mathrm{C}$-on nagyobb összrészecske-számot mértem, mint $120^{\circ} \mathrm{C}$-on. Igazoltam, hogy ez a jelenség a korom fraktál aggregátumok magasabb hőmérséklet hatására bekövetkező fragmentációjával magyarázható.

T4. Egy két hónapos, két városi mérési helyszínen végzett téli mérőkampány során vizsgáltam légköri széntartalmú aeroszol kémiai, fizikai és toxikológiai paramétereinek napszakos ingadozását, valamint a mért paraméterek között fennálló korrelációkat. Az optikai és mikrofizikai tulajdonságokat, úgy, mint fényelnyelés, fényszórás, méreteloszlás és tömegkoncentráció, a jelenleg legkorszerübb méréstechnikákkal mértem valós időben. A kémiai összetétel, valamint a toxicitás vizsgálatához (PAH és BTEX koncentráció, teljes és szerves széntartalom (TC és OC), levoglükozán (LG, valamint ökotoxicitás (EC50)) szürőpapíron gyüjtöttem mintát hatórás időfelbontásban. Biztos, de gyenge, valamint közepesen erős korrelációt találtam a városi széntartalmú aeroszol ökotoxicitása, valamint optikai, mikrofizikai és kémiai tulajdonságai között. Ez igazolja, hogy a városi széntartalmú szálló por ökotoxikus hatással rendelkezik. Közepes kapcsolatot találtam a filteres levegőmintákból Vibrio Fisheri bioluminesszcencia-gátlási teszt során meghatározott ökotoxicitás (EC50), valamint a valós időben fotoakusztikusan mért, az optikai abszorpció hullámhosszfüggését leíró fizikai mennyiség, az abszorpciós Angström exponens (AAE) között. Bemutattam, hogy a kibocsátó források szelektív azonosítására is bizonyítottan alkalmas AAE a levegő veszélyességének elsődleges monitorozására is képes indikátor lehet. 


\section{REFERENCES}

Aammi, S., Karaca, F. and Petek, M. (2017). A toxicological and genotoxicological indexing study of ambient aerosols (PM2.5-10) using in vitro bioassays. Chemosphere 174: 490-498.

Abdul-Khalek, I., Kittelson, D., Brear, F. (1999). The Influence of Dilution Conditions on Diesel Exhaust Particle Size Distribution Measurements. http://dx.doi.org/ 10.4271/1999-01-1142. SAE Technical Paper 1999-01-1142

Ahlvik, P., Ntziachristos, L., Keskinen, J., Virtanen, A. (1998). Real Time Measurements of Diesel Particle Size Distribution with an Electrical Low Pressure Impactor. http://dx.doi.org/10.4271/980410. SAE Technical Paper 980410 .

Ajtai, T., Filep, Á., Schnaiter, M., Linke, C., Vragel, M., Bozóki, Z., Szabó, G., Leisner, T. (2010a). A novel multiwavelength photoacoustic spectrometer for the measurement of the UV-Vis-NIR spectral absorption coefficient of atmospheric aerosols. J. Aerosol Sci. 41: 1020-1029.

Ajtai, T., Filep, Á., Kecskeméti, G., Hopp, B., Bozóki, Z., Szabó, G., (2010b) Wavelength dependent mass-specific optical absorption coefficients of laser generated coal aerosols determined from multi-wavelength photoacoustic measurements. Appl. Phys. A, 103: 1165-1172

Ajtai, T., Filep, Á., Utry, N., Schnaiter, M., Linke, C., M., Bozóki, Z:, Szabó, G.,Leisner, T. (2011). Intercomparison of optical absorption coefficients of atmospheric aerosols determined by a multi-wavelength photoacoustic spectrometer and an Aethalometer under sub-urban wintry conditions. J. Aerosol Sci. 42: 859-866.

Ajtai, T., Utry, N., Pintér, M., Kiss-Albert, G., Puskás, R., Tápai, Cs., Kecskeméti, G., Smausz, T., Hopp, B., Bozóki, Z., Kónya, Z., and Szabó, G. (2015). Micro-physical properties of carbonaceous aerosol particles generated by laser ablation of graphite target. Atmos. Meas. Tech 8: 1207-1215.

Ajtai, T., Utry, N., Pintér, M., Major, B., Bozóki, Z., \& Szabó, G. (2015). A method for segregating the optical absorption properties and the mass concentration of winter time urban aerosol. Atmospheric Environment, 122, 313-320.

Ajtai, T., Pintér, M., Utry, N., Kiss-Albert, G., Gulyás, G., Pusztai, P., Puskás, R., Bereczky, Á., Szabados, G., Szabó, G., Kónya, Z., Bozóki, Z. (2016). Characterisation of diesel particulate emission from engines using commercial diesel and biofuels, Atmospheric Environment, Volume 134, June 2016, Pages 109-120.

Andreae, M. O. and Merlet, P., (2001). Emission of trace gases and aerosols from biomass burning. Global Biogeochem. Cy., 15: 955-966.

Andreae, M. O. (2001). The dark side of aerosols. Nature, 409(6821), 671.

Andreae, M. O., Gelencsér, A, 2006. Black carbon or brown carbon? The nature of light absorbing carbonaceous aerosols Atmos. Chem. Phys., 6, 3131-3148

Andreae, M. O., \& Ramanathan, V. (2013). Climate's dark forcings. Science, 340(6130), 280-281.

Amato, F., Pandolfi, M., Escrig, A., Querol, X., Alastuey, A., Pey, J., Perez, N., Hopke, P.K. (2009). Quantifying road dust resuspension in urban environment by multilinear engine: a comparison with PMF2. Atmos. Environ. 43, 2770-2780.

Arnott, W. P., Hamasha, K., Moosmüller, H., Sheridan, P. J., \& Ogren, J. A. (2005). Towards aerosol lightabsorption measurements with a 7-wavelength aethalometer: Evaluation with a photoacoustic instrument and 3wavelength nephelometer. Aerosol Science and Technology,39(1), 17-29.

Aust, A. E., Ball, J. C., Hu, A. A., Lighty, J. S., Smith, K. R., Straccia, A. M., Veranth, J. M., Young, W. C. (2002) Particle characteristics responsible for effects on human lung epithelial cells. Res Rep Health Eff Inst; 110:67-76

Ács, A., Kovács, A., Ferincz, Á., Turóczi, B., Gelencsér, A., Kiss, G., Kováts, N. (2013). Characterisation of exhaust particulates from diesel-powered light-duty vehicles. Cent Eu r J Chem;1 1:1954-8.

Ballach, J., Hitzenberger, R., Schultz, E., \& Jaeschke, W. (2001). Development of an improved optical transmission technique for black carbon (BC) analysis. Atmospheric Environment, 35(12), 2089-2100. 
Ban-Weiss, G.A., Lunden, M.M., Kirchstetter, T.W., Harley, R.A. (2010). Size-resolved particle number and volume emission factors for on-road gasoline and diesel motor vehicles. Aerosol Sci. 41, 5-12.

Bauer, S.E., Y. Balkanski, M. Schulz, D.A. Hauglustaine, and F. Dentener, (2004). Global modelling of heterogeneous chemistry on mineral aerosol surfaces: The influence on tropospheric ozone chemistry and comparison to observations. J. Geophys. Res., 109, D02304

Bauer, J. J., Yu, X. Y., Cary, R., Laulainen, N., \& Berkowitz, C. (2009). Characterization of the sunset semicontinuous carbon aerosol analyzer. Journal of the Air \& Waste Management Association, 59(7), 826-833.

Baumgardner, D., Popovicheva, O., Allan, J., Bernardoni, V., Cao, J., Cavalli, F., Cozic, J., Diapouli, E., Eleftheriadis, K., Genberg, P. J., Gonzalez, C., Gysel, M., John, A., Kirchstetter, T. W., Kuhlbusch, T. A. J., Laborde, M., Lack, D., Müller, T., Niessner, R., Petzold, A., Piazzalunga, A., Putaud, J. P., Schwarz, J., Sheridan, P., Subramanian, R., Swietlicki, E., Valli, G., Vecchi, R., and Viana, M. (2012). Soot reference materials for instrument calibration and intercomparisons: a workshop summary with recommendations, Atmos. Meas. Tech., 5, 1869-1887, doi:10.5194/amt-5-1869-2012.

Belis, C., Karagulian, F., Bo, L., Hopke, P. (2013). Critical review and meta-analysis of ambient particulate matter source apportionment using receptor models in Europe. Atmos. Environ. 69, 94-108.

Bell, M. L., Davis, D. D. (2001) Reassessment of the lethal London fog of 1952: novel indicators of acute and chronic consequences of acute exposure to air pollution. Environ Health Perspect 109(3):389-394 Ann Allergy Asthma Immunol 2011;106(4):308-15.

Bell, M. L., Ebisu, K., Peng, R. D., Walker, J., Samet, J. M., Zeger, S. L., Dominici, F. (2008). Seasonal and regional short-term effects of fine particles on hospital admissions in 202 US counties, 1999-2005. American journal of epidemiology, 168(11), 1301-1310.

Bergstrom, R. W., Russell, P. B., Hignett, P. (2002). On the wavelenth dependence ofthe absorption of black carbon particles: predictions and results from the TARFOX experiment and implications for the aerosol single scattering albedo. J. Atmos. Sci., 59: 567-577

Bolin, B., \& Dôôs, B. R. (1989). Greenhouse effect. United States: N. p., Web.

Bond, T. C., Bergstrom, R.W., (2006) Light absorption by carbonaceous particles: an investigative review. Aerosol Sci. Tech. 40: 27-67

Bond, T. C., S. J. Doherty, D.W. Fahey, P.M. Forster, T. Berntsen, B.J. DeAngelo, M.G. Flanner, S. Ghan, B. Kärcher, D. Koch, S. Kinne, Y. Kondo, P.K. Quinn, M.C. Sarofim, M.G. Schultz, M. Schulz, C. Venkataraman, H. Zhang, S. Zhang, N. Bellouin, S. K. Guttikunda, P.K. Hopke, M.Z. Jacobson, J. W. Kaiser, Z. Klimont, U. Lohmann, J. P. Schwarz, D. Shindell, T. Storelvmo, S. G. Warren, and C.S. Zender, (2013). Bounding the role of black carbon in the climate system: A scientific assessment. J. Geophys. Res. Atmos., 118: 5380-5552

Bozóki, Z., Pogány, A., Szabó, G. (2011) Photoacoustic instruments for practical applications: present, potentials and future challenges. Appl. Spectrosc. Rev. 46: 1-37

Budapest környezeti állapotértékelése (2014): http://budapest.hu/Documents/Bp\%20K\%C3\%B6rnyezeti\%20\%C3\%811lapot\%C3\%A9rt\%C3\%A9kel\%C3\%A9 se\%202014.pdf, Last Access: 1 June 2016.

Bukowiecki, N., Kittelson, D.B., Watts, W.F., Burtscher, H., Weingartner, E., Baltensperger, U. (2012). Real-time characterization of ultrafine and accumulation mode particles in ambient combustion aerosols. Aerosol Sci. 33, $1139-1154$

Buschini, A., Cassoni, F., Anceschi, E., Pasini, L., Poli, P. and Rossi, C. (2001). Urban airborne particulate: genotoxicity evaluation of different size fractions by mutagenesis tests on microorganisms and comet assay. Chemosphere 44: 1723-1736.

Burtscher, H. (2005). Physical characterization of particulate emissions from diesel engines: a review. Journal of Aerosol Science, 36(7), 896-932. 
Burtscher, H., Baltensperger, U., Bukowiecki, N., Cohn, P., HuKglin, C., Mohr, M., Matter, U., Nyeki, S., Schmatloch, V., Streit, N., Weingartner, E. (2001). Separation of volatile and non-volatile aerosol fractions by thermodesorption: instrumental development and applications. Aerosol Sci. 32, 427-442

Cerna, M., Pochmanova, D., Pastorkova, A., Benes, I., Linícek, J., Topinka, J. and Bianková, B. (2000). Genotoxicity of urban air pollutants in the Czech Republic. Part I. Bacterial mutagenic potencies of organic compounds adsorbed on PM10 particulates. Mutat. Res. 469: 71-82.

Chakrabarty, R. K., Moosmüller, H., Chen, L.-W. A., Lewis, K., Arnott, W. P., Mazzoleni, C., Dubey, M. K., Wold, C.E., Hao, W. M. and Kreidenweis, S. M. (2010). Brown carbon in tar balls from smoldering biomass combustion. Atmos. Chem. Phys., 10: 6363-6370

Chakrabaty, R.K., Beres, N.D., Moosmüller, H., China, S., Mazzoleni, C., Dubey, M.K., Liu, L., Miscchenko, M.I. (2014). Soot superaggregates from flaming wildfires and their direct radiative forcing. Nat. Sci. Rep. 4, 5508.

Champion, W. M. (2017). Navajo Home Heating Practices, Teir Impacts on Air Quality and Human Health, and a Framework to Identify Sustainable Solutions. Doctoral Thesis. University of Colorade, Boulder.

Charlson, R. J. and Heinzenberg, J. (1994). Aerosol Forcing of Climate, John Wiley \& Sons, pp. 416.

Chen, R. J., Chen, B. H., Kan, H. D. (2010). A health-based economic assessment of particulate air pollution in 113 Chinese cities. China Environ Sci;30(3):410-5.

Cheng, M.-D. (2013). Classification of volatile engine particles. Aerosol Air Qual. Res. 13, 1411-1422

Claquin, T., Schulz, M., Balkanski, Y., \& Boucher, O. (1998) Uncertainties in assessing radiative forcing by mineral dust. Tellus B, 50(5): 491-505

Curtius, J, (2006). Nucleation of atmospheric aerosol particles C. R. Physique 7.

Czövek, D., Novák, Z., Somlai, C., Asztalos, T., Tiszlavicz, L., Bozóki, Z., Ajtai, T., Utry, N., Filep, Á., Bari, F. andPeták, F. (2012). Respiratory consequences of red sludgedust inhalation in rats. Toxicol. Lett. 209: 113-120

Dockery, D., \& Pope, A. (1996). Epidemiology of acute health effects: summary of time-series studies. Particles in our air: Concentrations and health effects, 123-147.

Dockery, D.W., Pope, C.A., III, Xu, X., Spengler, J.D., Ware, J.H., Fay, M.E., Ferris, B.G. and Speizer, F.E.(1993). An association between air pollution and mortalityin six U.S. cities. N. Engl. J. Med. 329: 1753-1759.

Donaldson, K., Brown, D., Clouter, A., Duffin, R., MacNee, W., Renwick, L., Tran, L. and Stone, V. (2002). The pulmonary toxicology of ultrafine particles. J. Aerosol Med. 15: 213-220.

Donaldson, K., Beswick, P.H. and Gilmour, P.S. (1996). Free radical activity associated with the surface of particles: A unifying factor in determining biological activity? Toxicol. Lett. 88: 293-298.

ECE, 2000. Uniform Provisions Concerning the Approval of Compression-ignition (CI) and Natural Gas (NG) Engines as Well as Positive-ignition (PI) Engines Fuelled with Liquefied Petroleum Gas (LPG) and Vehicles Equipped with CI and NG Engines and PI Engines Fuelled with LPG, with Regard to the Emissions of Pollutants by the Engine. Regulation No. 49, Revision 3. E/ECE/324. Economic Commission for Europe

Favez, O., Cachier, H., Sciare, J., Sarda-Esteve, R. and Matinon, L. (2009). Evidence for a significant contribution of wood burning aerosols to PM2.5 during the winter season in Paris, France. Atmos. Environ. 43: 3640-3644.

Favez, O., El Haddad, I., Piot, C., Boreave, A., Abidi, E., Marchand, N., Jaffrezo, J.L., Besombes, J.L., Personnaz, M.Z., Sciare, J., Wortham, H., George, C. and D'Anna, B. (2010). Inter-comparison of source apportionment models for the estimation of wood burning aerosols during wintertime in an Alpine city (Grenoble, France). Atmos. Chem. Phys. 10: 5295-5314

Feng, Y., Ramanathan, V., and Kotamarthi, V. R. (2013) Brown carbon: a significant atmospheric absorber of solar radiation? Atm. Chem. Phys., 13: 8607-8621

Fierz, M., Vernooij, M.G.C., Burtscher, H. (2007). An improved low-flow thermodenuder. J. Aerosol Sci. 38 (11), 1163-1168 
Filep, Á., Ajtai, T., Utry, N., Pintér, M. D., Nyilas, T., Takács, S., Máté, Zs., Gelencsér, A., Hoffer, A., Schnaiter, M., Bozóki, Z., Szabó, G. (2013). Absorption spectrum of ambient aerosol and its correlation with size distribution in specific atmospheric conditions after a red mud accident. Aerosol and Air Quality Research, 13(4).

Filep, Á., Drinovec, L., Palágyi, A., Manczinger, L., Vágvölgyi, Cs., Bozóki, Z., Hitzenberger, R. and Szabó, G. (2015). Source specific cyto- and genotoxicity of atmospheric aerosol samples. Aerosol Air Qual. Res. 15: 23252331

Fine, P.M., Cass, G.R. and Simoneit, B.R.T. (2002). Chemical characterization of fine particle emissions from the fireplace combustion of woods grown in the southern United States. Environ. Sci. Technol. 36: 1442-1451.

Finlayson-Pitts, B.J., Pitts, J.N. (2000). Chemistry of the Upper and Lower Atmosphere-theory, Experiments, and Applications. Academic Press, San Diego, CA, ISBN 978-0-12-257060-5

Flowers, B. A., Dubey, M. K., Mazzoleni, C., Stone, E. A., Schauer, J. J., Kim, S.-W. (2010) Optical-chemical relationships for carbonaceous aerosols observed at Jeju Island, Korea with a 3-laser photoacoustic spectrometer. Atmos. Chem. Phys. Discuss., 10: 9369-9389.

Furhstorfer, P. and Niessner, R. (1994). Identification and Classification of Airborne Soot Particles Using an Automated SEM/EDX, Mikrochim. Acta, 1134, 239-250.

Gelencsér, A. (2004). Carbonaceous Aerosol, Springer-Verlag GmbH, ISBN 10: 1402028865/ISBN 13: 9781402028861.

Guaita R, Pichiule M, Mate T, Linares C, Diaz J. (2001). Short-term impact of particulate matter (PM2.5) on respiratory mortality in Madrid. Int J Environ Health Res; 21:260-74.

Guo, X., Nakayama, T., Yamada, H., Inomata, S., Tonokura, K., Matsumi, Y. (2014). Measurement of the light absorbing properties of diesel exhaust particles using a three-wavelength photoacoustic spectrometer. Atmos. Environ. 94, 428-437.

Gysel, M., Laborde, M., Olfert, J. S., Subramanian, R., and Gröhn, A. J. (2011). Effective density of Aquadag and fullerene soot black carbon reference materials used for SP2 calibration, Atmos. Meas. Tech., 4, 2851-2858, doi:10.5194/amt-4-2851-2011.

Harris, S.J., Maric, M.M. (2002). The role of fragmentation in defining the signature size distribution of diesel soot. J. Aerosol Sci. 33 (6), 935-942

Hayakawa, K., Kawaguchi, Y., Murahashi, T. and Miyazaki, M. (1995). Distributions of nitropyrenes and mutagenicity in airborne particulates collected with an Andersen sampler. Mutat. Res. 348: 57-61

Hawa, T. and Zachariah, M. (2006). Coalescence kinetics of unequal sized nanoparticles, J. Aerosol Sci., 37, 115.

Heintzenberg, J. (1994). Properties of the log-normal particle size distribution. Aerosol Science and Technology, 21(1), 46-48.

Helsper, C., Mölter, W., Loffler, F., Wadenpohl, C., Kaufmann, S., Wenninger, G. (1993). Investigations of a new aerosol generator for the introduction of carbon aggregate particles. Athmospheric Environment, Vol. 27, No. 8., pp. 1271-1275

Hitzfeld, B, Friedrichs, K. H, Ring J, Behrendt, H. (1997). Airborne particulate matter modulates the production of reactive oxygen species in human polymorphonuclear granulocytes. Toxicology;120(3):185-95

Hoffer, A., Gelencsér, A., Guyon, P., Kiss, G., Schmid, O., Frank, G.P., Artaxo, P., Andreae, M.O., (2006) Optical properties of humic-like substances (HULIS) in biomass-burning aerosols. Atmos. Chem. Phys. 6: 3563-3570

Hopp, B., Kecskeméti, G., Smausz, T., Ajtai, T., Filep, A., Utry, N., Kohut, A., Bozóki, Z., and Szabó, G. (2012). Characterization of excimer laser ablation generated pepsin particles using multiwavelength photoacoustic instrument, Appl. Phys. A, 107, 429-435.

Horvath, H. (1993). Atmospheric light absorption-A review. Atmospheric Environment. Part A. General Topics, 27(3), 293-317. 
Horvath, H. and Gangl, M. (2003). A low-voltage spark generator for production of carbon particles, J. Aerosol. Sci., 34, 1581-1588.

Hou, Q., An, X. Q., Wang, Z. F., Wang, Y., Sun, Z. B. (2011). Assessment on health economic costs of particulate air pollution in Lanzhou during 2002-2009. China Environ Sci;31(8): 1398-402.

Hou, Q., An, X., Wang, Y., Tao, Y., \& Sun, Z. (2012). An assessment of China's PM10-related health economic losses in 2009. Science of the total environment, 435, 61-65.

IARC (International Agency for Research on Cancer) (2012). Diesel and Gasoline Engine Exhausts and Some Nitroarenes, IARC Monographs on the Evaluation of Carcinogenic Risks to Human, Lyon, Vol. 46 (1989)

Ishiguro, T., Takatori, Y., \& Akihama, K. (1997). Microstructure of diesel soot particles probed by electron microscopy: first observation of inner core and outer shell. Combustion and flame, 108(1-2), 231-234.

IPCC, 2013: Climate Change 2013: The Physical Science Basis. Contribution of Working Group I to the Fifth Assessment Report of the Intergovernmental Panel on Climate Change. [editor: Stocker, T. F., D. Qin, G.-K. Plattner, M. Tignor, S. K. Allen, J. Boschung, A. Nauels, Y. Xia, V. Bex and P. M. Midgley] (Cambridge University Press, Cambridge, United Kingdom and New York, NY, USA, 1535 pp.

Jacobson MC, Hansson H-C, Noone KJ, Charlson RJ. (2000) Organic atmospheric aerosols: review and state of the science. Reviews of Geophysics 38: 267-94

John, W. (2011) Size Distribution Characteristics of Aerosols, in Aerosol Measurement: Principles, Techniques, and Applications (3rd Ed.). Kulkarni, P., Baron, P. A. and Willeke, K. (Ed.s). John Wiley \& Sons, Inc., Hoboken, NJ, USA. doi: 10.1002/9781118001684.ch4

Jullien, R., \& Botet, R. (1987). Aggregation and fractal aggregates. Ann. Telecomm., 41, 343-short.

Karagulian, F., Belis, C. A., Dora, C. F. C., Prüss-Ustün, A. M., Bonjour, S., Adair-Rohani, Heather, Amann, M. (2015). Contributions to cities' ambient particulate matter (PM): A systematic review of local source contributions at global level. Atmospheric Environment 120 475-483

Karanasiou, A., Minguillón, M. C., Viana, M., Alastuey, A., Putaud, J. P., Maenhaut, W., Panteliadis, P., Močnik, G., Favez, O. Kuhlbusch, T. A. J. (2015). Thermal-optical analysis for the measurement of elemental carbon (EC) and organic carbon (OC) in ambient air a literature review. Atmospheric Measurement Techniques Discussions, $8(9)$.

Kawanaka, Y., Wang, N., Yun, S.J. and Sakamoto, K. (2002). Size distributions and seasonal variations in concentrations of 1- nitropyrene and polycyclic aromatic hydrocarbons in atmospheric particulate matter. J. Environ. Chem. 12: 599-607.

Kazakov, A., \& Frenklach, M. (1998). Dynamic modeling of soot particle coagulation and aggregation: Implementation with the method of moments and application to high-pressure laminar premixed flames. Combustion and Flame, 114(3-4), 484-501.

Kelly, P.M., Jones, P.D. and Jia Pengqun, (1996). The spatial response of the climate system to explosive volcanic eruptions. International Journal of Climatology 16(5), 537-550

Kiehl, J. T. (2007). Twentieth century climate model response and climate sensitivity. Geophysical Research Letters, 34(22).

Klimont, Z., Smith, S. J., and Cofala, J. (2013). The last decade of global anthropogenic sulfur dioxide: 20002011 emissions, Environ. Res. Lett., 8, 014003, doi:10.1088/1748-9326/8/1/014003.

Kirchstetter, T. W., Novakov, T., and Hobbs, P. V., (2004). Evidence that the spectral dependence of light absorption by aerosols is affected by organic carbon, J. Geophys. Res.-Atmos., 109, D21208.

Kirchstetter, T. W. and Novakov, T. (2007). Controlled generation of black carbon particles from acombustion flame and applications in evaluating black carbon measurement methods, Atmos. Environ., 41, 1874-1888, doi:10.1016/j.atmosenv.2006.10.067. 
Kiss, G., Varga-Puchony, Z., Rohrbacher G. and Hlavay, J. (1998). Distribution of polycyclic aromatic hydrocarbons on atmospheric aerosol particles of different sizes. Atmos. Res. 46: 253-261

Kiss, G. (2007). A légköri finom szerves aeroszol kémiai jellemzése és a felhőképződésben betöltött szerepének vizsgálata. Doktoral Thesis.

Kittleson, D.B. (1998). Engines and nanoparticles: a review. J. Aerosol Sci. 29 (5/6), 575-588.

de Kok, T.M.C.M., Driece, H.A.L., Hogervorst, J.G.F. and Briede, J.J. (2006). Toxicological assessment of ambient and traffic-related particulate matter: A review of recent studies. Mutat. Res. 613: 103-122.

Koppmann, R., von Czapiewski, K. and Reid, J.S. (2005). A review of biomass burning emissions, Part I: Gaseous emissions of carbon monoxide, methane, volatile organic compounds, and nitrogen containing compounds. Atmos. Chem. Phys. Discuss. 5: 10455-10516.

Kováts, N., Ács, A., Kovács, A., Ferincz, Á., Turóczi, B., and Gelencsér, A. (2012). Direct contact test for estimating the ecotoxicity of aerosol samples. Environ. Toxicol. Pharmacol. 33: 223-228.

Kováts, N., Ács, A., Ferincz, Á., Kovács, A., Horváth, E., Kakasi, B., Jancsek-Turóczi, B. and Gelencsér, A. (2013). Ecotoxicity and genotoxicity assessment of exhaust particulates from diesel-powered buses. Environ. Monit. Assess. 185: 8707-8713. Kováts, N. and Horváth, E. (2016). Bioluminescence-based assays for assessing eco- and genotoxicity of airborne emissions. Luminescence 31: 918-923.

Kulmala, M., Kontkanen, J., Junninen, H., Lehtipalo, K., Manninen, H.E., Nieminen, T., Petäjä, T., Sipilä, M., Schobesberger, S., Rantala, P., Franchin, A., Jokinen, T., Järvinen, E., Äijälä, M., Kangasluoma, J., Hakala, J., Aalto, P.P., Paasonen, P., Mikkilä, J., Vanhanen, J., Aalto, J., Hakola, H., Makkonen, U., Ruuskanen, T., Mauldin, R.L., Duplissy, J., Vehkamäki, H., Bäck, J., Kortelainen, A., Riipinen, I., Kurtén, T., Johnston, M.V., Smith, J.N., Ehn, M., Mentel, T.F., Lehtinen, K.E.J., Laaksonen, A., Kerminen, V.-M., Worsnop, D.R. (2013). Direct observations of atmospheric aerosol nucleation. Science 339:943-946. https://doi.org/10.1126/science.1227385

Lack, D.A., Lovejoy, E.R., Baynard, T. amf Pettersson, A. (2006). Aerosol absorption measurement using photoacoustic spectroscopy: sensitivity, calibration and uncertainty developments. Aerosol Sci. Technol. 40: 697708

Lack, D. A., Langridge, J. M., Bahreini, R., Cappa, C. D., Middlebrook, A. M., \& Schwarz, J. P. (2012). Brown carbon and internal mixing in biomass burning particles. Proceedings of the National Academy of Sciences, 109(37), 14802-14807.

Lamarque, J.-F., T.C. Bond, V. Eyring, C. Granier, A. Heil, Z. Klimont, D. Lee, C. Liousse, A. Mieville, B. Owen, M.G. Schultz, D. Shindell, S.J. Smith, E. Stehfest, J. Van Aardenne, O.R. Cooper, M. Kainuma, N. Mahowald, J.R. McConnell, V. Naik, K. Riahi, and D.P. van Vuuren, (2010) Historical (1850-2000) gridded anthropogenic and biomass burning emissions of reactive gases and aerosols: Methodology and application. Atmos. Chem. Phys., 10: 7017-7039

Landkocz, Y., Ledoux, F., André, V., Cazier, F., Genevray, P., Dewaele, D., Martin, P. J., Lepers, C., Verdin, A., Courcot, L., Boushina, S., Sichel, F., Gualtieri, M., Shirali, P., Courcot, D. and Billet, S. (2017). Fine andultrafine atmospheric particulate matter at a multiinfluenced urban site: Physicochemical characterization, mutagenicity and cytotoxicity. Environ. Pollut. 221: 130-140

Lapuerta, M., Rodríguez-Fernandez, J., Agudelo, J.R. (2008a). Diesel particulate emissions from used cooking oil biodiesel. Bioresour. Technol. 99 (4), 731-740.

Lapuerta, M., Armas, O., Rodríguez-Fernandez, J. (2008b). Effect of biodiesel fuels on diesel engine emissions. Prog. Energy Combust. Sci. 34 (2), 198-223.

Lee Rodgers, J., \& Nicewander, W. A. (1988). Thirteen ways to look at the correlation coefficient. The American Statistician, 42(1), 59-66.

Li, N., Wang, M.Y., Bramble, L.A., Schmitz, D.A., Schauer, J.J., Sioutas, C., Harkema, J.R. and Nel, A.E. (2009). The adjuvant effect of ambient particulate matter is closely reflected by the particulate oxidant potential. Environ. Health Perspect. 117: 1116-1123. 
Li, N., Sioutas, C., Cho, A., Schmitz, D., Misra, C., Sempf, J., Wang, M.Y., Oberley, T., Froines, J. and Nel, A. (2003). Ultrafine particulate pollutants induce oxidative stress and mitochondrial damage. Environ. Health Perspect. 111: 455-460.

Limbeck, A., Kulmala, M., Puxbaum, H., (2003). Secondary organic aerosol formation in the atmosphere via heterogeneous reaction of gaseous isoprene on acidic particles. Geophysical Research Letters 30, 19

Lin, T.H. and Chao, M.R. (2002). Assessing the influence of methanolcontaining additive on biological characteristics of diesel exhaust emissions using microtox and mutatox assays. Sci. Total Environ. 284: 61-74

Lin, Y.-C., Lee, C.-F., Fang, T. (2008). Characterization of particle size distribution from diesel engines fueled with palm-biodiesel blends and paraffinic fuel blends. Atmos. Environ. 42, 1133-1143

Linke, C., Ibrahim, I., Schleicher N., Hitzenberger, R., Andreae, M. O., Leisner T., Schnaiter, M. (2016). A novel single-cavity three-wavelength photoacoustic spectrometer for atmospheric aerosol research. Atmos. Meas. Tech., 9, 5331-5346

Liousse, C., Cachier, H., \& Jennings, S. G. (1993). Optical and thermal measurements of black carbon aerosol content in different environments: Variation of the specific attenuation cross-section, sigma (?). Atmospheric Environment. Part A. General Topics, 27(8), 1203-1211

Liu, G.Z., Vasys, V.N., Kittleson, D.B. (2007). Nuclei-mode particulate emissions and their response to fuel sulfur content and primary dilution during transient operations of old and modern diesel engines. Environ. Sci. Technol. 41 (18), 6479-6483. http://dx.doi.org/10.1021/es0629007

Lloyd, A.C., Cackette, T.A. (2001). Diesel engines: environmental impact and control. J. Air Waste Manage Assoc. 51 (6), 809-847

Longhin, E., Gualtieri, M., Capasso, L., Bengalli, R., Mollerup, S., Holme, J A., Øvrevik, J., Casadei, S., DiBenedetto, C., Parenti, P. and Camatini, M. (2016). Physico-chemical properties and biological effects ofdiesel and biomass particles. Environ. Pollut. 215 366-375

Mathis, U., Ristimaki, J., Mohr, M., Keskinen, J., Ntziachristos, L., Samaras, Z., Mikkanen, P. (2004). Sampling conditions for the measurement of nucleation mode particles in the exhaust of a diesel vehicle. Aerosol Sci. Technol. 38 (12), 1149e1160. http://dx.doi.org/10.1080/027868290891497

Márton, Z., Landström, L., \& Heszler, P. (2004). Early stage of the material removal during ArF laser ablation of graphite. Applied Physics A, 79(3), 579-585.

Masui, T., Matsumoto, K., Hijioka, Y., Kinoshita, T., Nozawa, T., Ishiwatari, S., Kato, E., Shukla, P. R., Yamagata, Y., and Kainuma, M. (2011). An emission pathway for stabilization at $6 \mathrm{~W} \mathrm{~m}$-2radiative forcing, Clim. Change, 109, 59-76.

McCormack, M. C., Breysse, P. N., Matsui, E. C., Hansel, N. N., Peng, R. D., Curtin-Brosnan, J., Williams, D., Wills-Karp, M., Diette, G. B. (2011). Indoor particulate matter increases asthma morbidity in children with nonatopic and atopic asthma. Annals of Allergy, Asthma \& Immunology, 106(4), 308-315.

Molnár, A., Mészáros, E., Hansson, H.C., Karlson, H., Gelencsér, A., Kiss, Gy., Krivácsy, Z., (1999) The importance of organic and elemental carbon in the fine atmospheric aerosol. Atmospheric E nvironm ent 33: 27452750 .

Moore, R. H., Ziemba, L.D., Dutcher, D., Beyersdorf, A.J., Chan, K., Crumeyrolle, S., Raymond, T.M., Thornhill, K.L., Winstead, E.L. and Anderson, B.E., (2014) Mapping the Operation of the Miniature Combustion Aerosol Standard (MiniCAST) Soot Generator. Aerosol Sci. Technol. 48: 467-479

Muala, A., Nicklasson, H., Boman, C., Swietlicki, E., Nyström, R., Pettersson, E., Bosson, J.A., Rissler, J., Blomberg, A., Sandström, T. and Löndahl, J. (2014). Respiratory tract deposition of inhaled wood smoke particle in healthy volunteers. J. Aerosol Med. Pulmon. Drug Delivery 28: 237-246

Nemery B, Hoek P, Nemmar A (2001) The Meuse Valley fog of 1930: an air pollution disaster. Lancet 357:704708 
Papadimitriou, C.A., Haritou, I., Samaras, P. and Zouboulis, A.I. (2008). Evaluation of leaching and ecotoxicological properties of sewage sludge-fly ash mixtures. Environ. Res. 106: 340-348.

Park, K., Kittleson, D. B., and McMurry, P. H. (2004). Structural Properties of Diesel Exhaust Particles Measured by Transmission Electron Microscopy (TEM): Relationships to Particle Mass and Mobility, AerosolSci. Tech., 38, $881-889$.

Pearson, J. F., Bachireddy, C., Shyamprasad, S., Goldfine, A. B., Brownstein, J. S. (2010). Association between fine particulate matter and diabetes prevalence in the U.S. Diabetes Care;33(10):2196.

Penner, J.E., Hegg, D. and Leaitch, R. (2001). Unraveling the role of aerosols in climate change. Environ. Sci. Technol. 35: 332A-340A

Petzold, A., Kopp, C., \& Niessner, R. (1997). The dependence of the specific attenuation cross-section on black carbon mass fraction and particle size. Atmospheric Environment, 31(5), 661-672.

Petzold, A. and Niessner, R. (1996). Photoacoustic soot sensor for in-situ black carbon monitoring. Appl. Phys. B., 63: 191-197

Petzold, A., Ogren, J. A., Fiebig, M., Laj, P., Li, S.-M., U. Baltensperger, U., Holzer-Popp, T., Kinne, S., Pappalardo, G., Sugimoto, N., Wehrli. C., Wiedensohler, A., Zhang, X.-Y. (2013). Recommendations for reporting "black carbon" measurements. Atmos. Chem. Phys., 13, 8365-8379.

Pintér, M., Utry, N., Ajtai, T., Kiss-Albert, G., Jancsek-Turóczi, B., Imre, K., Palágyi, A., Manczinger, L., Vágvölgyi, Cs., Horváth, E., Kováts, N., Gelencsér, A., Szabó, G., Bozóki, Z. (2017). Optical Properties, Chemical Composition and the Toxicological Potential of Urban Particulate Matter. Aerosol and Air Quality Research, 17, 1415-1426.

Pintér, M., Ajtai, T., Kiss-Albert, G., Kiss, D., Utry, N., Janovszky, P., Palásti, D., Smausz, T., Kohut, A., Hopp, B., Galbács, G., Kukovecz, Á., Kónya, Z., Szabó, G., Bozóki, Z. (2018). Thermo-optical properties of residential coals and combustion aerosols. Atmospheric Environment, 178, 118-128.

Pope, C.A., III, Burnett, R.T., Thun, M.J., Calle, E.E., Krewski, D., Ito, K. and Thurston, G.D. (2002). Lungcancer, cardiopulmonary mortality, and long-term exposure to fine particulate air pollution. JAMA 287:1132-1141.

Popovicheva, O.B., Kireeva, E.D., Steiner, S., Rothen-Rutishauser, B., Persiantseva, N.M., Timofeev, M.A., Shonija, N.K., Comte, P., Czerwinski, J. (2014). Microstructure and chemical composition of diesel and biodiesel particle exhaust. Aerosol Air Qual. Res. 14, 1392-1401

Pósfai, M., Gelencsér, A., Simonics, R., Arató, K., Li, J., Hobbs, P. V., \& Buseck, P. R. (2004). Atmospheric tar balls: Particles from biomass and biofuel burning. Journal of Geophysical Research: Atmospheres, 109(D6).

Pöschl, U. (2003) Aerosol particle analysis: challenges and progress. Analytical and bioanalytical chemistry, 375 : 30-32.

Puxbaum, H., Caseiro, A., Sánchez-Ochoa, A., KasperGiebl, A., Claeys, M., Gelencsér, A., Legrand, M., Preunkert, S. and Pio, C. (2007). Levoglucosan levels at background sites in Europe for assessing the impact of biomass combustion on the European aerosol background. J. Geophys. Res. 112: D23S05.

Puzun, A., Wanchen, S., Guoliang, L., Manzhi, T., Chunjie, L., Shibao, C. (2011). Characteristics of particle size distributions about Emissions in A Common-rail diesel engine with biodiesel blends. Proc. Environ. Sci. 11, 13711378

Randall, L. and Vander, W. (2010). A TEM Methodology for the Study of Soot Particle Structure, Combustion Sci. Tech., 126, 333-351.

Redmond, H. E., Dial, K. D, Thompson, J. E. (2010). Light scattering and absorption by wind blown dust: theory, measurement, and recent data. Aeolian Research, 2, 5-26.

Riahi, K., Rao, S., Krey, V., Cho, C., Chirkov, V., Fischer, G., Kindermann, G., Nakicenovic, N., and Rafaj, P. (2011). RCP 8.5 - A scenario of comparatively high greenhouse gas emissions, Clim. Change, 109, 33-57. 
Rissler, J., Swietlicki, E., Bengtsson, A., Boman, C., Pagels, J., Sandstrom, T., Blomberg, A., Londahl, J. (2012). Experimental determination of deposition of diesel exhaust particles in the human respiratory tract. J. Aerosol Sci. $48,18-33$

Roig, N., Sierra, J., Rovira, J., Schuhmacher, M., Domingo, J.L. and Nadal, M. and (2013). In vitro tests to assess toxic effects of airborne PM10 samples. Correlation with metals and chlorinated dioxins and furans. Sci. Total Environ. 443: 791-797.

Ronkkö, T., Virtanen, A., Kannosto, J., Keskinen, J., Lappi, M., Pirjola, L. (2007). Nucleation mode particles with a nonvolatile core in the exhaust of a heavy duty diesel vehicle. Environ. Sci. Technol. 41 (18), 6384-6389

Rothenbacher, S., Messerer, A., Kasper, G. (2008). Fragmentation and bond strength of airborne diesel soot agglomerates. Part. Fibre Toxicol. 5, 9.

Sakurai, H., Tobias, H.J., Park, K., Zarling, D., Docherty, K.S., Kittelson, D.B., McMurry, P.H., Ziemann, P.J., (2003). On-line measurements of diesel nanoparticle composition and volatility. Atmos. Environ. 37 (9-10), 11991210 .

Salma, I, Németh, Z., Weidinger, T., Maenhaut, W., Claeys, M., Molnár, M., Major, I., Ajtai, T., Utry, N., Bozóki, Z. (2017). Source apportionment of carbonaceous chemical species to fossil fuel combustion, biomass burning and biogenic emissions by a coupled radiocarbonlevoglucosan marker method. Atmos. Chem. Phys. Discuss., doi:10.5194/acp-2017-406.

Sandradewi, J., Prevot, A.S.H., Szidat, S., Perron, N., Alfarra, M.R., Lanz, V.A., Weingartner, E. and Baltansperger, U. (2008a). Using aerosol light absorption measurements for thequantitative determination of wood burning and traffic emission contributions to particulate matter. Environ. Sci. Technol. 42: 3316-3323.

Sandradewi, J., Prevot, A.S.H., Weingartner, E., Schmidhauser, R., Gysel, M. and Baltensperger, U. (2008b). A study of wood burning and traffic aerosols in an Alpine valley using a multi-wavelength Aethalometer. Atmos. Environ. 42: 101-112

Santer, B. D., Taylor, K. E., Wigley, T. M., Penner, J. E., Jones, P. D., \& Cubasch, U. (1995). Towards the detection and attribution of an anthropogenic effect on climate. Climate Dynamics, 12(2), 77-100.

Sempere, R., Kawamura, K. (1994) Comparative distributions of dicarboxylic acids and related polar compounds in snow, rain and aerosols from urban atmosphere, Atmospheric Environment, 28, 449-45.

Sexton, K., Liu, K-S., Hayward, S. B., Spengler, J. D. (1985). Characterization and source apportionment of wintertime aerosol in a wood-burning community, Atmospheric Environment 19, 1225-1236.

Shiraiwa, M., Kondo, Y., Moteki, N., Takegawa N., Sahu, L.K., Takami, A., Hatakeyama, S., Yonemura, S. and Blake, D.R. (2008). Radiative impact of mixing state of black carbon aerosol in Asian outflow. J. Geophys. Res. 113: D24210

Schnelle-Kreis, J., Gebefugi, I., Welzl, G., Jaensch, T. and Kettrup, A. (2001). Occurrence of particle-associated polycyclic aromatic compounds in ambient air of the city of Munich. Atmos. Environ. 35: S71-S81.

Schmid, O., Artaxo, P., Arnott, W. P., Chand, D., Gatti, L. V., Frank, G. P., Andreae, M. O. (2006). Spectral light absorption by ambient aerosols influenced by biomass burning in the Amazon Basin. I: Comparison and field calibration of absorption measurement techniques. Atmospheric Chemistry and Physics, 6(11), 3443-3462.

Schnaiter, M., Horvath, M., Möhler, O., Naumann, K. H., Saathol, H., and Schöck, O. W. (2003). UV-VIS-NIR spectral optical properties of soot and soot-containing aerosols, Aerosol Sci., 34, 1421-1444.

Schnaiter, M., Gimmler, M., Llamas, I., Linke, C., Jäger, C., and Mutschke, H. (2006). Strong spectral dependence of light absorption by organic carbon particles formed by propane combustion, Atmos. Chem. Phys., 6, 29812990, doi:10.5194/acp-6-2981-2006.

Schulz, M., Textor, C., Kinne, S., Balkanski, Y., Bauer, S., Berntsen, T., Boucher, O., Dentener, F., Guibert, S., Isaksen, I. S. A., Iversen, T., Koch, D., Kirkevag, A., Liu, X., Montanaro, V., Myhre, G., Penner, J. E., Pitari, G., Reddy, S., Seland, O., Stier, P., Isaksen, I. S. A. (2006). Radiative forcing by aerosols as derived from the AeroCom present-day and pre-industrial simulations. Atmospheric Chemistry and Physics, 6(12), 5225-5246. 
Schwartz, J. (1994). Air pollution and hospital admissions for the elderly in Birmingham, Alabama. Am. J. Epidemiol. 139: 589-598

Schwartz, S. E. (1996). The whitehouse effect-Shortwave radiative forcing of climate by anthropogenic aerosols: An overview. Journal of Aerosol Science, 27(3), 359-382.

Seinfeld, J. H., Pandis, S. N. (2006). Atmospheric chemistry and physics - from airpollution to climate change (2nd edition). John Wiley \& Sons.

Sigsgaard, T., Forsberg, B., Annesi-Maesano, I., Blomberg, A., Bolling, A., Boman, C6, Bonlokke, J., Brauer, M., Bruce, N., Héroux, M.E., Hirvonen, M.R., Kelly, F., Künzli, N., Lundbäck, B., Moshammer, H., Noonan, C., Pagels, J., Sallsten, G., Sculier, J. and Brunekreef, B. (2015). Health impacts of anthropogenic biomass burning in the developed world. Eur. Respir. J. 46: 1577-1588

Sharma, N., Arnold, I. J., Moosmüller, H., Arnott, W. P., \& Mazzoleni, C. (2013). Photoacoustic and nephelometric spectroscopy of aerosol optical properties with a supercontinuum light source. Atmospheric Measurement Techniques, 6(12), 3501.

Simon, K. A., Ajtai, T., Gulyás, G., Utry, N., Pintér, M., Szabó, G., Bozóki, Z. (2017). Accuracy assessment of aerosol source apportionment by dual wavelength photoacoustic measurements. Journal of Aerosol Science, Volume 104, pp 10-15.

Smausz, T., Kondász, B., Gera, T., Ajtai, T., Utry, N., Pintér, M., Kiss-Albert, G., Budai, J, Bozóki, Z., SZabó, G., Hopp, B. (2017). Determination of UV-visible-NIR absorption coefficient of graphite bulk using direct and indirect methods. Applied Physics A, 123(10), 633.

Smith, S. J., \& Bond, T. C. (2014). Two hundred fifty years of aerosols and climate: the end of the age of aerosols. Atmospheric Chemistry and Physics, 14(2), 537-549.

Solomon, S., Qin, D., Manning, M., Chen, Z., Marquis, M., Averyt, K.B., Tignor, M. and Miller, H.L. (2007). Contribution of Working Group I to the Fourth Assessment Report of the Intergovernmental Panel on Climate Change. Cambridge University Press, Cambridge, United Kingdom and New York, NY, USA

Song, J., Alam, M., and Boehman, A. L.: Characterization of diesel and biodiesel soot, Prepr. Pap.-AM. Chem. Soc., DIv. Fuel Chem., 49, 769, 2004.

Spanner, G., Schröder, H., Petzold, A., and Niessner, R. (1994) Geneartion of carbon aerosols by fragmentation of acetylene in a laserinduced plasme, J. Aerosol Sci., 25, 265-275.

Steinbeck, J., Braunstein, G., Dresselhaus, M. S., Venkatesan, T., \& Jacobson, D. C. (1985). A model for pulsed laser melting of graphite. Journal of applied physics, 58(11), 4374-4382.

Steiner, S., Czerwinski, J., Comte, P., Popovicheva, O., Kireeva, E., Müller, L., Heeb, N., Mayer, A., Fink, A., Rothen-Rutishauser, B., (2013). Comparison of the toxicity of diesel exhaust produced by bio- and fossil diesel combustion in human lung cells in vitro. Atmos. Environ. 81, 380-388

Stevanovic, S., Miljevic, B., Madl, P., Clifford, S., Ristovski, Z. (2015). Characterisation of a commercially available thermodenuder and diffusion drier for ultrafine particles losses. Aerosol Air Qual. Res. 15, 357-363

Schwartz, S.E. (2004). Uncertainty requirements in radiative forcing of climate change. J. Air Waste Manage. Assoc. 54: 1351-1359

Tegen, I., \& Fung, I. (1994). Modeling of mineral dust in the atmosphere: Sources, transport, and optical thickness. Journal of Geophysical Research: Atmospheres, 99(D11), 22897-22914.

Tinsdale, M., Price, P., Chen, R. (2010). The impact of biodiesel on particle number, size and mass emissions from a Euro4 diesel vehicle. SAE Int. J. Eng. 3 (1), 597-608

Thomson, A. M., Calvin, K. V., Smith, S. J., Kyle, G. P., Volke, A., Patel, P., Delgado-Arias, S., Bond-Lamberty, B., Wise, M. A., Clarke, L. E. and Edmonds, J. A. (2011). RCP4.5: A Pathway for Stabilization of Radiative Forcing by 2100, Clim. Change, 109, 77-94, doi:10.1007/s10584-011-0151-4. 
Trapel, E., Mayer, C., Schulz, C., Roth, P. (2005). Effects of Bio Diesel Injection in a DI Diesel Engine on Gaseous and Particulate Emission. http://dx.doi.org/10.4271/ 2005-01-2204. SAE Technical Paper 2005-01-2204

Tumolva, L., Park, J.-Y., Kim, J., Miller, A. L., Chow, J. C., Watson, J. G., and Park, K. (2010). Morphological and Elemental Classification of Freshly Emitted Soot Particles and Atmospheric Ultrafine Particles using the TEM/EDS, Aerosol Sci. Tech., 44, 202-215.

Turóczi, B., Hoffer, A., Tóth, Á., Kováts, N., Ács, A., Ferincz, Á., Kovács, A. and Gelencsér, A. (2012). Comparative assessment of ecotoxicity of urban aerosol. Atmos. Chem. Phys. 12: 7365-7370

Turrio-Baldassarri, L., Battistelli, C. L., Conti, L., Crebelli, R., De Berardis, B., Iamiceli, A. L., Gambino, M., Iannaccone, S. (2004). Emission comparison of urban bus engine fueled with diesel oil and 'biodiesel' blend. Sci. Total Environ. 327, 147-162.

Uhrner, U., Zallinger, M., von Lowis, S., Vehkam € aki, H., Wehner, B., Stratmann, F., Wiedensohler, A. (2011). Volatile nanoparticle formation and growth within a diluting diesel car exhaust. J. Air Waste Manag. Assoc. 61 (4), 399-408

Utry, N., Ajtai, T., Pintér, M., Illés, E., Tombácz, E., Szabó, G., Bozóki, Z. (2017). Generation and UV-VIS-NIR spectral responses of organo-mineral aerosol for modeling soil derived dust. Atmospheric Environment, Volume 152, March 2017, Pages 553-561.

Utry, N., Ajtai, T., Pintér, M., Tombácz, E., Illés, E., Bozóki, Z., Szabó, G. (2014). Mass specific optical absorption coefficients of mineral dust components measured by a multi wavelength photoacoustic spectrometer. Atmos. Measur. Tech. Dis, 7, 9025-9046.

Utry, N., Ajtai, T., Filep, Á., Pintér, M., Török, Z., Bozóki, Z., Szabó, G. (2014). Correlations between absorption Angström exponent (AAE) of wintertime ambient urban aerosol and its physical and chemical properties. Atmospheric environment, 91, 52-59.

Utry, N., Ajtai, T., Pintér, M., Bozóki, Z., Szabó, G. (2014). Wavelength-Dependent Optical Absorption Properties of Artificial and Atmospheric Aerosol Measured by a Multi-Wavelength Photoacoustic Spectrometer. International Journal of Thermophysics, 35(12), 2246-2258.

Utry, N., Ajtai, T., Filep, Á., Pintér, M. D., Hoffer, A., Bozoki, Z., \& Szabó, G. (2013). Mass specific optical absorption coefficient of HULIS aerosol measured by a four-wavelength photoacoustic spectrometer at NIR, VIS and UV wavelengths. Atmospheric environment, 69, 321-324.

Valavanidis A, Fiotakis K, Vlachogianni T. (2008). Airborne particulate matter and human health: toxicological assessment and importance of size and composition of particles for oxidative damage and carcinogenic mechanisms. J Environ Sci Health C Environ Carcinog Ecotoxicol Rev;26(4):339-62.

van Vuuren, D. P., Stehfest, E., den Elzen, M. G. J., Kram, T., van Vliet, J., Deetman, S., Isaac, M., Goldewijk, K. K., Hof, A., Beltran, A. M., Oostenrijk, R., and van Ruijven, B. (2011). RCP2.6: exploring the possibility to keep global mean temperature increase below $2{ }^{\circ} \mathrm{C}$, Clim. Change, 109, 95-116.

Venkatesan, T., Jacobson, D. C., Gibson, J. M., Elman, B. S., Braunstein, G., Dresselhaus, M. S., \& Dresselhaus, G. (1984). Measurement of thermodynamic parameters of graphite by pulsed-laser melting and ion channeling. Physical review letters, 53(4), 360.

Verma, V., Ning, Z., Cho, A.K., Schauer, J.J., Shafer, M.M. and Sioutas, C. (2009). Redox activity of urban quasiultrafine particles from primary and secondary sources. Atmos. Environ. 43: 6360-6368.

Verma, V., Rico-Martinez, R., Kotra, N., King, L., Liu, J., Snell, T.W. and Weber, R.J. (2012). Contribution of water-soluble and insoluble components and their hydrophobic/hydrophilic subfractions to the reactive oxygen species-generating potential of fine ambient aerosols. Environ. Sci. Technol. 46: 11384-11392

Viidanoja, J., Sillanpää, M., Laakia, J., Kerminen, V. M., Hillamo, R., Aarnio, P., \& Koskentalo, T. (2002). Organic and black carbon in PM2. 5 and PM10: 1 year of data from an urban site in Helsinki, Finland. Atmospheric Environment, 36(19), 3183-3193. 
Vouitsis, E., Ntziachristos, L., Pistikopoulos, P., Samaras, Z., Chrysikou, L., Samara, C., Papadimitriou, C., Samaras, P. and Sakellaropoulos, G. (2009). An investigation on the physical, chemical and ecotoxicological characteristics of particulate matter emitted from light-duty vehicles. Environ. Pollut. 157: 2320-2327

Ward, B. J., Yacob, T. W., \& Montoya, L. D. (2014). Evaluation of solid fuel char briquettes from human waste. Environmental science \& technology, 48(16), 9852-9858.

XuSheng, Z., Hui, Z., ZongJie, H., ZhiJun, W., LiGuang, L. (2009). Effect of biodiesel on the particle size distribution in the exhaust of common-rail diesel engine and the mechanism of nanoparticle formation. Sci. China Ser. E-Tech Sci. 52 (9), 2773e2778. http://dx.doi.org/10.1007/s11431-009-0100-x.

Zender, C. (2015). Particle Size Distributions: Theory and Application to Aerosols, Clouds, and Soils. University of Carlifornia at Irvine, Department of Earthly System Science. Online University Note: $\underline{\text { http://patarnott.com/pdf/SizeDistributions.pdf }}$

Zhang, R., Khalizov, A. F., Pagels, J., Zhang, D., Xue, H., \& McMurry, P. H. (2008). Variability in morphology, hygroscopicity, and optical properties of soot aerosols during atmospheric processing. Proceedings of the National Academy of Sciences, 105(30), 10291-10296. 


\section{SCIENTIFIC ACTIVITY}

Scientific articles related to thesis statements:

T1. Ajtai, T., Utry, N., Pintér, M., Kiss-Albert, G., Puskás, R., Tápai, Cs., Kecskeméti, G., Smausz, T., Hopp, B., Bozóki, Z., Kónya, Z., and Szabó, G. (2015). Micro-physical properties of carbonaceous aerosol particles generated by laser ablation of graphite target. Atmos. Meas. Tech 8: 1207-1215.

IF:2.929

Number of independent citations: 0

T2-T3. Ajtai, T., Pintér, M., Utry, N., Kiss-Albert, G., Gulyás, G., Pusztai, P., Puskás, R., Bereczky, Á., Szabados, G., Szabó, G., Kónya, Z., Bozóki, Z. (2016) Characterisation of diesel particulate emission from engines using commercial diesel and biofuels, Atmospheric Environment, Volume 134, June 2016, Pages 109-120.

IF: 3.281

Number of independent citations: 4

T4. Pintér, M., Utry, N., Ajtai, T., Kiss-Albert, G., Jancsek-Turóczi, B., Imre, K., Palágyi, A., Manczinger, L., Vágvölgyi, Cs., Horváth, E., Kováts, N., Gelencsér, A., Szabó, G., Bozóki, Z. (2017). Optical Properties, Chemical Composition and the Toxicological Potential of Urban Particulate Matter. Aerosol and Air Quality Research, 17, 1415-1426.

IF: 2.606

Number of independent citations: 1

Conference posters and presentations related to the thesis statements:

Pintér, M., Kiss-Albert, G., Utry, N., Ajtai, T., Szabó, G., Bozóki, Z.. Investigating the Source Dependence of Aethalometer Correction Factors Using an In-House Developed Multi-Wavelength PhotoAcoustic Spectrometer. AAAR 2017 Raleigh NC USA

Pintér M., Kiss-Albert G., Utry N., Ajtai T., Szabó G., Bozóki Z. Légköri aeroszol complex mikrofizikai és spektrális tulajdonságainak vizsgálata téli városi környezetben. Tavaszi Szél 2017, Miskolc, Hungary

Pintér, M., Utry, N., Gulyás, G., Kiss-Albert, G., Ajtai, T., Szabó, G., Bozóki, Z. A thermodenuder assisted dualwavelength dual cell photoacoustic aerosol analyser with enhanced source apportionment capability. European Aerosol Conference 2016, Tours, France

Ajtai, T., Utry, N., Pintér, M., Kiss-Albert, G., Szabó, G., Bozóki, Z. Thermal analysis of diesel emitted particulate matter. European Aerosol Conference 2016, Tours, France

Utry, N., Pintér, M., Ajtai, T., Kiss-Albert, G., Palágyi, P., Manczinger, L., Vágvölgyi, Cs., Imre, K., JancsekTúróczi, B., Gelencsér, A., Szabó, G., Bozóki, Z. Correlations between the toxicity and optical properties of 
atmospheric aerosol measured by self-developed photoacoustic and supplementary instrumentation. European Aerosol Conference 2016, Tours, France

Ajtai, T., Pinter, M., Utry, N., Kiss-Albert, G., Palágyi, A., Manczinger, L., Vágvölgyi, CS., Szabó, G., Bozóki, Z. On the possibility of real time air quality and toxicology assessment using multiwavelength photoacoustic spectroscopy. EGU 2016, Vienna, Austria,

Ajtai, T., Pinter, M., Utry, N., Kiss-Albert, G., Palágyi, A., Manczinger, L., Vágvölgyi, CS., Szabó, G., Bozóki, Z. On the possibility of real time characterisation of ambient toxicity using multi-wavelength photoacoustic instrument. ICAST 2016, Lisbon, Portugal

Ajtai, T., Pintér, M., Utry, N., Kiss-Albert, G., Gulyás, G., Bereczky, Á., Szabados, Gy., Bozóki, Z., Szabó, G. Thermal evolution and dynamic changes in diesel emission. EAC 2015. Milan, Italy

Ajtai, T., Utry, N., Pintér, M., Szabados, Gy., Bereczky, Á., Kiss-Albert, G., Gulyás, G., Bozóki, Z., Szabó, Gr. Dízel korom aeroszolok karakterizálása: A motorterhelés és a kipufogógáz hőmérsékletének hatása a méreteloszlásra. MAK 2015, Szeged, Hungary.

Ajtai, T., Utry, N., Pintér, M., Kecskeméti, G., Smausz, T., Hopp, B., Bozóki, Z., Szabó, G. Generation and characterization of laser induced carbon particles. IAC 2014. Busan, Korea

Pintér, M., Ajtai, T., Utry, N., Bozóki, Z., Szabó, G. Mesterséges és légköri korom aeroszolok optikai abszorpciós tulajdonságainak vizsgálata saját fejlesztésü négy-hullámhosszú fotoakusztikus spektrométerrel. A „Kvantumelektronika 2014: VII. Szimpózium a hazai kvantumelektronikai kutatások eredményeiről” és a Modern Fényforrások és Alkalmazásaik workshop. BME 2014. november 28, Budapest, Hungary.

Ajtai, T., Utry, N., Pintér, M., Bozóki, Z., Szabó, G. Generation and characterization of laser induced carbon particles. Tavaszi szél 2014, Debrecen, Hungary.

Ajtai, T., Utry, N., Pintér, M., Bozóki, Z., Szabó, G. Lézergenerált koromaeroszolok előállítása és karakterizálása. Magyar Aeroszol konferencia 2013. Debrecen, Hungary.

\section{Other relevant scientific articles in the topic:}

Pintér, M., Ajtai, T., Kiss-Albert, G., Kiss, D., Utry, N., Janovszky, P., Palásti, D., Smausz, T., Kohut, A., Hopp, B., Galbács, G., Kukovecz, Á., Kónya, Z., Szabó, G., Bozóki, Z. (2018). Thermo-optical properties of residential coals and combustion aerosols. Atmospheric Environment, 178, 118-128.

IF.: 3.629 
Smausz, T., Kondász, B., Gera, T., Ajtai, T., Utry, N., Pintér, M., Kiss-Albert, G., Budai, J, Bozóki, Z., Szabó, G., Hopp, B. (2017). Determination of UV-visible-NIR absorption coefficient of graphite bulk using direct and indirect methods. Applied Physics A, 123(10), 633.

IF: 1.455

Utry, N., Ajtai, T., Pintér, M., Illés, E., Tombácz, E., Szabó, G., Bozóki, Z. (2017). Generation and UV-VIS-NIR spectral responses of organo-mineral aerosol for modeling soil derived dust. Atmospheric Environment, Volume 152, March 2017, Pages 553-561.

IF: 3.459

Simon, K. A., Ajtai, T., Gulyás, G., Utry, N., Pintér, M., Szabó, G., Bozóki, Z. (2017). Accuracy assessment of aerosol source apportionment by dual wavelength photoacoustic measurements. Journal of Aerosol Science, Volume 104, pp 10-15.

IF: 2.278

Ajtai, T., Utry, N., Pintér, M., Major, B., Bozóki, Z., \& Szabó, G. (2015). A method for segregating the optical absorption properties and the mass concentration of winter time urban aerosol. Atmospheric Environment, 122, 313-320.

IF:3.281

Utry, N., Ajtai, T., Pintér, M., Tombácz, E., Illés, E., Bozóki, Z., \& Szabó, G. (2014). Mass specific optical absorption coefficients of mineral dust components measured by a multi wavelength photoacoustic spectrometer. Atmos. Measur. Tech. Dis, 7, 9025-9046.

IF: 2.929

Utry, N., Ajtai T., Smausz Kolumbán, T., Kecskeméti G., Tápai Cs., Pintér M., Hopp B., Bozóki Z. (2014). Lézergenerált korom-aeroszolok fotoakusztikus vizsgálata. Fizikai Szemle. 233-236.

Utry, N., Ajtai, T., Filep, Á., Pintér, M., Török, Z., Bozóki, Z., \& Szabó, G. (2014). Correlations between absorption Angström exponent (AAE) of wintertime ambient urban aerosol and its physical and chemical properties. Atmospheric environment, 91, 52-59.

IF: 3.281

Utry, N., Ajtai, T., Pintér, M., Bozóki, Z., \& Szabó, G. (2014). Wavelength-Dependent Optical Absorption Properties of Artificial and Atmospheric Aerosol Measured by a Multi-Wavelength Photoacoustic Spectrometer. International Journal of Thermophysics, 35(12), 2246-2258.

IF: 0.963

Filep, Á., Ajtai, T., Utry, N., Pintér, M. D., Nyilas, T., Takács, S., Máté, Zs., Gelencsér, A., Hoffer, A., Schnaiter, M., Bozóki, Z., Szabó, G. (2013). Absorption spectrum of ambient aerosol and its correlation with size distribution in specific atmospheric conditions after a red mud accident. Aerosol and Air Quality Research, 13(4).

IF: 2.664

Utry, N., Ajtai, T., Filep, Á., Pintér, M. D., Hoffer, A., Bozoki, Z., \& Szabó, G. (2013). Mass specific optical absorption coefficient of HULIS aerosol measured by a four-wavelength photoacoustic spectrometer at NIR, VIS and UV wavelengths. Atmospheric environment, 69, 321-324.

IF: 3.062 


\section{ACKNOWLEDGEMENT}

I would like to express my gratitude to my supervisor, Dr. Tibor Ajtai for helping my research throughout the years. I would also like to thank leaders of the MTA-SZTE Research Group on Photoacoustic Spectroscopy, Prof. Dr. Zoltán Bozóki and Prof. Dr. Gábor Szabó for providing an opportunity to work in an intriguing field of research in a professional environment. I would especially like to thank Dr. Noémi Utry for introducing me to the beauty of aerosol science. Without her, this work would never have been completed. I would also like to thank Gergely Kiss-Albert for his humble and dedicated work and for bringing laughter to monotonous workdays.

I am also grateful to

- Members and graduate students of the Research Group on Photoacoustic Spectroscopy who made any kind of contribution to my work.

- Co-workers of the Research Group on Laser Ablation (especially Prof. Dr. Hopp Béla, Dr. Tomi Smausz Kolumbán and Csaba Tápai)

- Dr. Gábor Motika and co-workers of the Lower Tisza Valley Environmental Inspectorate (its present name: Government office of Csongrád county), Szeged, Hungary

- Co-workers of the Department of Applied and Environmental Chemistry at the University of Szeged for taking TEM pictures and aiding morphological investigations

- Co-workers of the Department of Earth and Environmental Sciences at the University of Pannonia

- Co-workers of Institute of Environmental Sciences at the Pannon University

- Dr. Kornélia Imre and co-workers of MTA-PTE Air Chemistry Research Group

- Co-workers of the Department of Energy Engineering, University of Technology and Economics

- Co-workers of KTI-Institute for Transport Sciences, Budapest

- Dr. Aladár Czitrovszky and Dr. Attila Nagy from the Wigner Research Center for Physics

- Dr. Tamás Weidinger from Eötvös Loránd University, Department of Meteorology

- Co-workers of Hilase Ltd., especially Gábor Gulyás

- Co-workers of the Hungarian Meteorological Service

- Dr. Anna Gulyásné Szabó for proofreading my dissertation

- Attila Molnár for his help during field measurement campaigns 
The following research grants ensured financial support for my research:

- Hungarian Scientific Research Foundation (OTKA, project no. K101905)

- Hungarian Scientific Research Foundation (OTKA, project no. NN 109679)

- TÁMOP-4.2.2.A-11/1/KONV-2012-0047

- TÁMOP-4.2.2.A-11/1/KONV-2012-0060

- TAMOP-4.2.2.B-15/1/KONV-2015-0006

- GOP-1.1.1-11-2012-0114

- GINOP-2.3.2-15-2016-00036

- EFOP-3.6.1-16-2016-00014

- National Talent Scholarship of the Ministry of Human Capacities, Hungary

- Campus Mundi Scholarship

I am also grateful to my partner, my family and friends both with us and gone for believing in me my all these years. I would have never made it through without their humour, support and love. 